\title{
contra la leptospirosis
}

Alejandra Mariel Habarta

\author{
Tesis Doctoral 2009
}

\section{Ricardo Martín Gómez \\ Director}

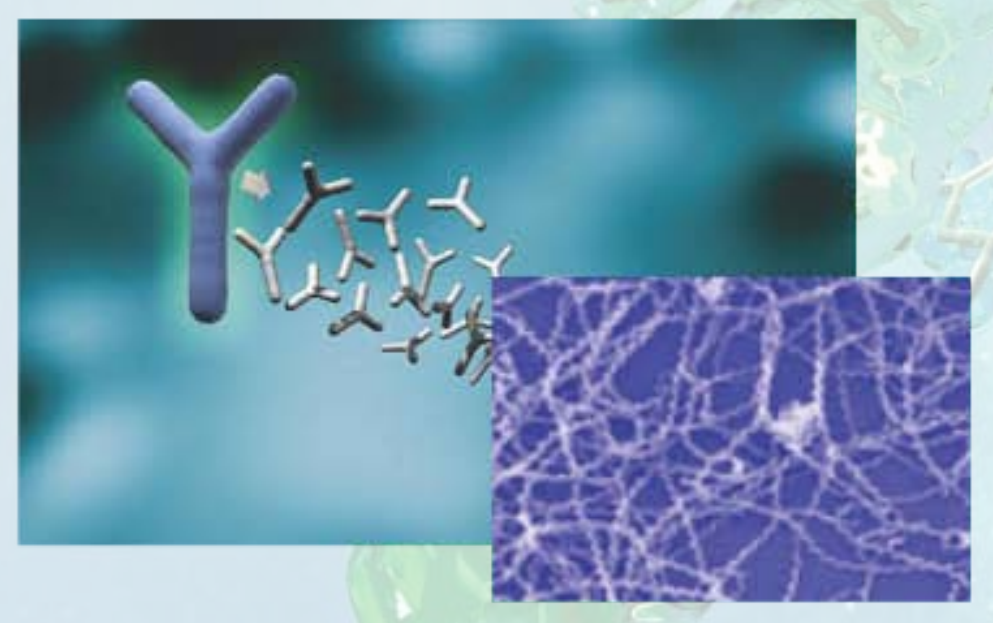


Tesis Doctoral 2009

Alejandra Mariel Habarta

Clonado y validación de candidatos vacunales contra la leptospirosis

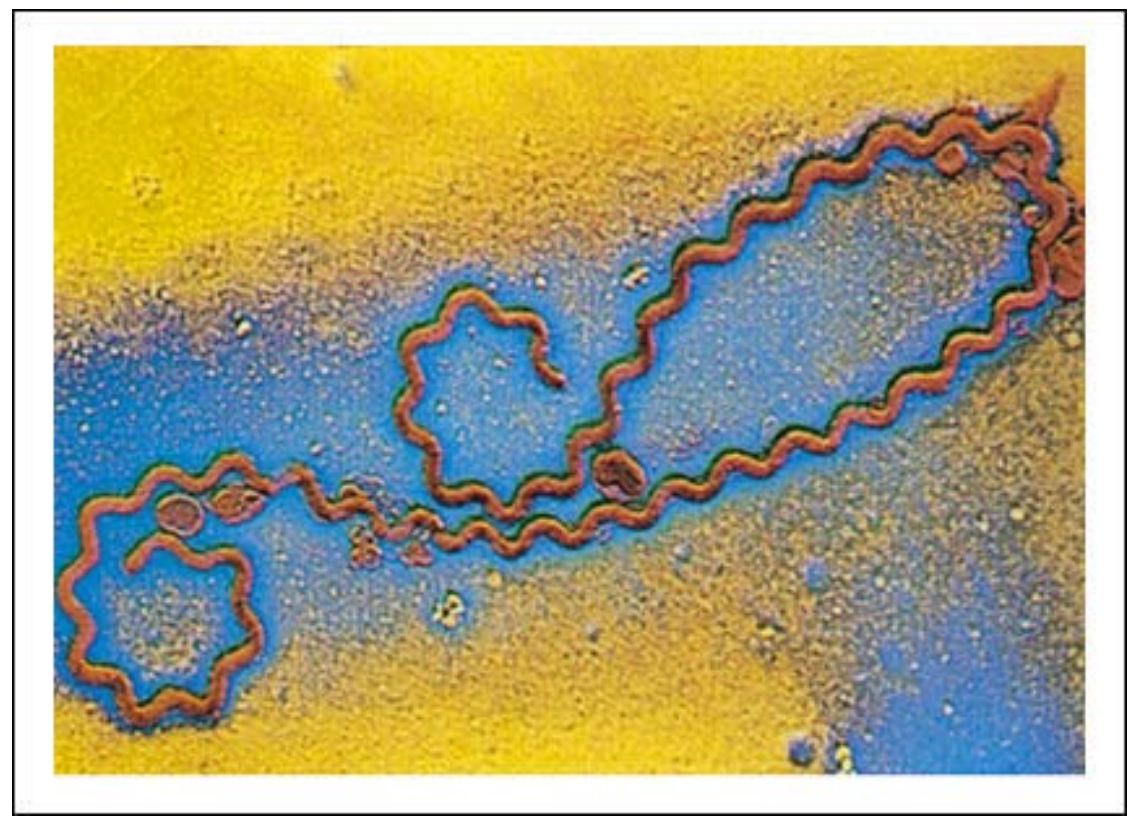


El presente trabajo de Tesis para optar al grado de Doctor de la Facultad de Ciencias Exactas ha sido realizado en el Instituto de Biotecnología y Biología Molecular (IBBM) de la Facultad de Ciencias Exactas de la Universidad Nacional de La Plata/CONICET bajo la dirección del Dr. Ricardo M. Gómez. 


\section{Agradecimientos}

- Al Dr Ricardo M Gómez por haberme dado la posibilidad de realizar esta tesis y haberme brindado todo su apoyo.

- Al Concejo Nacional de Investigaciones Científicas y Técnicas (CONICET), a la Agencia Nacional de Promoción Científica y Tecnológica (ANPCyT), a la Universidad Nacional de La Plata (UNLP) y al Instituto de Biotecnología y Biología Molecular (IBBM) por haber hecho posible la realización del presente trabajo.

- Al Dr Paulo Lee Ho y a la Dra Ana Lucia T. O. Nascimento del Centro de Biotecnología del Instituto Butantan, San Pablo, Brasil, por habernos brindado su colaboración y experiencia en todo lo necesario para la realización de este trabajo.

- A la Dra Mirta Schattner y a todo su laboratorio de Trombosis I en La Academia Nacional de Medicina por ayudarnos con los cultivos de células endoteliales y la citometría de Flujo que este trabajo demandó.

- Al Laboratorio de Zoonosis del Hospital Muñiz por habernos brindado inestimable ayuda en los ensayos de desafio.

- Al Dr Ezequiel Lupo por habernos ayudado en la interpretación de los datos histopatológicos.

- Al laboratorio de virus animales (Ricky, Colo, Mini, Leti, Caro, Javo, Fer) por tantos momentos compartidos, mates de por medio, o cualquier otro arte culinario.

- A los amigos que quedaran después de la finalización de este trabajo.

- A todos mis amigos del alma que están conmigo en los momentos más lindos como en los más difíciles.

- Por último a las personas más importantes en mi vida: mi tío, que siempre esta ahí para contenerme; mi hijo, que es mi sol de cada mañana y mi luna de cada noche, y mis padres, por su apoyo incondicional. Sin ellos no hubiera podido lograr ser la persona que soy.

- A todos MUCHAS GRACIAS!! 
Indice

Pagina

Título

Objetivo

Agradecimientos

Indice

Indice de Figuras y Tablas

Lista de Abreviaciones
I

II

III

IV

VIII

$\mathrm{X}$ 
1 Introducción

1.1 Espiroquetas 1

1.2 Leptospiras 2

1.3 Leptospirosis 4

1.3.1 Reservorio 5

1.3.2 Mecanismo de transmisión 5

1.3.3 Prevalencia e incidencia en la Republica Argentina 6

1.3.4 Historia Natural $\quad 7$

$\begin{array}{ll}\text { 1.3.5 Síndrome de Weil } & 10\end{array}$

1.3.6 Datos de laboratorio 10

1.3.7 Respuesta inmune 11

1.3.8 Patogénesis 11

1.3.9 Diagnóstico 12

1.3.10 Pruebas serológicas 13

1.3.11 Diagnóstico diferencial 13

1.3.12 Tratamiento 13

1.3.13 Pronóstico 14

1.3.14 Profilaxis 14

1.3.15 Medidas de control $\quad 15$

1.3.16 Vigilancia epidemiológica 15

1.3.17 Impacto socio-económico 16

1.4 Busqueda de antígenos recombinantes útiles en diagnostico o $\begin{array}{ll}\text { prevención } & 16\end{array}$

1.4.1 Justificación de los candidatos seleccionados $\quad 18$

1.5 Toxina colérica y su utilidad como adyuvante 19

1.6 Objetivos específicos 24

2 Materiales y Métodos 25

2.1 Productos químicos y enzimas 25

2.2 Medios 25

$\begin{array}{ll}\text { 2.2.1 LB (Luria-Bertani) } & 25\end{array}$ 
2.2.2 Medio Enriquecido EMJH para Leptospira 25

2.2.3 Medio RPMI 25

2.3 Cepas bacterianas utilizadas 26

2.3.1 Cepas de Leptospira 26

2.3.2 Cepas de Escherichia coli 26

2.4 Plásmidos 27

2.4.1 PAE 27

2.4.2 PAE-СTВ 27

2.5 Selección in silico de LIC10365 29

2.6 Aislamiento de DNA genómico bacteriano 30

2.7 Reacción en cadena de la polimerasa (PCR) 30

2.8 Minipreps 31

2.9 Digestión por enzimas de restricción 31

2.10 Electroforesis en gel de agarosa 31

2.11 Purificación de fragmentos de DNA 32

2.12 Reacción de Ligación 32

2.13 Obtención de células competentes $\quad 34$

2.14 Transformación 34

2.15 Cinética de expresión $\quad 35$

2.16 Expresión, purificación y renaturalización 36

2.16.1 Expresión 36

2.16.2 Purificación y renaturalización 37

2.17 Antisueros contra rLIC10365 y CTB-LipL32 37

2.18 SDS-PAGE e inmunoblotting 38

2.19 ELISA 38

2.20 Extracción de RNA y análisis de (RT)-PCR 39

2.21 Inmunohistoquímica 39

2.22 Ensayo de lisado de Limulus amebocyto (LAL test) 40

2.23 Cultivo de células endoteliales 40

2.24 Expresión de las moléculas de adhesión celular (CAMs) Eselectina e ICAM-1 
2.25 Desafío. Respuesta de los animales desafiados 42

2.25.1 Mortalidad 42

2.25.2 Histopatología 42

2.25.3 Carga bacteriana $\quad 42$

2.26 Respuesta inmune humoral 43

2.27 Análisis estadístico 43

3 Resultados $\quad 44$

3.1 LIC10365 44

3.1.1 Análisis bioinformático de la secuencia de LIC10365 44

3.1.2 Expresión protéica, purificación y western blot 44

3.1.3 Conservación de genes y proteínas entre

cepas de Leptospira 45

3.1.4 Evaluación inmunohistoquímica con suero anti-rLIC10365 46

3.1.5 Expresión de E-selectina e ICAM-1 en células endoteliales 47

3.2 CTB-LipL32 49

3.2.1 Construcción del vector CTB-LIPL32 49

3.2.2 Expresión protéica, purificación y western blot de CTB-LipL32 50

3.2.3 Secuenciamiento de la construcción 51

3.2.4 Demostración de la estructura pentamérica de la proteína recombinante CTB-LipL32 52

3.2.5 Reconocimiento de la proteína por suero de raton inmunizado 53

3.2.6 Reconocimiento de la proteína recombinante CTB-LipL32 por sueros de pacientes convalescientes 54

3.2.7 Inmunización y posterior desafío 56

3.2.8 Mortalidad $\quad 56$

3.2.9 Analisis histopatológico 57

3.2.10 Análisis inmunohistoquímico 58 
3.2.11 Analisis de la respuesta inmune humoral

4 Discusión

4.1 LIC10365

60

4.2 CTB-LipL32

62

5 Conclusiones

67

6 Referencias

68 


\section{Indice de Figuras y Tablas}

\section{Introducción}

Figura 1.1 Fotografía con microscopio electrónico de barrido de Leptospira spp. 2

Figura 1.2 Esquema de la morfología de Espiroquetas. 3

Figura 1.3 Ciclo de transmisión de la leptospirosis. 6

Figura 1.4 Naturaleza bifásica de la leptospirosis y sus características en la enfermedad en diferentes estadíos.

Figura 1.5 Mapa circular de los 2 cromosomas en Leptospira interrogans. 17

Figura 1.6 Esquema del pentámero conformado por la subunidad B de la toxina colérica y su interacción con el receptor celular GM1. 21

Figura 1.7 Esquema de la conformación del gangliósido GM1. 22 Tabla 1.1 Algunas características de las enfermedades producidas por Espiroquetas 1

Tabla 1.2 Genes seleccionados de LIC. 20

\section{Materiales y Métodos}

Figura 2.1 Esquema de los vectores pAE (arriba) y pAE-CTB (abajo). 28

Figura 2.2 Secuencia del gen CTB modificada. 29

Figura 2.3 Esquema del clonado de Lic10365. 33

Figura 2.4 Esquema de la construcción de pAE- CTB-LipL32. 34

Tabla 2.1 Genotipos de las cepas de E.coli utilizadas 26

\section{Resultados}

Figura 3.1 Expresión, purificación y western blot de rLIC10365.

Figura 3.2 Conservación de genes y proteínas entre cepas de Leptospira. 46

Figura 3.3 Inmunohistoquímica en tejido renal.

Figura 3.4 Inducción de la expresión de ICAM-1 y de E-selectinas de superficie en HUVECs, por rLIC10365.

Figura 3.5 Clonación de pAE CTB-LipL 32. 49

Figura 3.6 Expresión, purificación y western blot de CTB-LipL32 (rP). 51 
Figura 3.7 Imagen representativa del cromatograma realizado para corroborar el correcto clonado de las proteínas y su marco de lectura. 51 Figura 3.8 Comprobación del correcto plegado de CTB-LipL32 y la formación del pentámero.

Figura 3.9 Reconocimiento de CTB-LipL32 por sueros murinos. 54

Figura 3.10A Reconocimiento de sueros de pacientes convalecientes contra CTB-LipL32.

Figura 3.10B Reconocimiento de sueros de pacientes sanos contra CTB-LipL32. 55

Figura 3.10C Reactividad de sueros humanos con CTB-LipL32. 56

$\begin{array}{ll}\text { Figura 3.13 Sobrevida de hamster inmunizados y desafiados con LIC. } & 57\end{array}$ Figura 3.14 Histopatología de areas corticales y medulares renales de hamsters de 3-4 semanas de edad a los 14 días PI.

Figura 3.15 Inmunohistoquimica de areas corticales renales de hamsters de 3-4 semanas de edad a los 14 días PI empleando un pool de antisueros contra diversas proteínas de superficie de LIC.

Figura 3.17 Respuesta inmune humoral. 


\section{Abreviaciones}

$\mu \mathrm{l}$ : microlitros

$\mu \mathrm{g}$ : microgramos

$\mu \mathrm{m}$ : micrometros

aá: aminoácidos

Amp: ampicilina

AMP: adenosín monofosfato

BSA: albúmina de suero bovino

CAMs: del inglés cell adhesion molecules

Cl: cuerpos de inclusión

cm: centímetros

CPK: creatina fosfoquinasa

CT: toxina colérica

CTA: subunidad A de la toxina colérica

CTB: subunidad B de la toxina colérica

Da: Daltons

DAB: 3,3-diaminobenzidina

DTT: ditiotreitol

dNTPs: deoxinucleótidos trifosfato

DO: densidad óptica

ECG: electrocardiograma

EDTA: ácido etilendiamintetraacético

ELISA: del ingles enzyme-linked immunoabsorbent assay

F: primer forward

FITC: isotiocianato de fluoresceína

G: gravedad

gr: gramos

GM1: gangliósido M1

His-tag: secuencia de 6 histidinas

HRP: del inglés horseradish peroxidase

hs: horas 
HUVECs: Células endoteliales humanas derivadas de cordón umbilical

I: Inducido

Ig: Inmunoglobulinas

IPTG: isopropil- $\beta$-D-tio-galactósido

iv: intravenosa

kb: kilobase

kDa: kilodalton

Kg: kilogramo

L: litro

LAL: lisado de Limulus amebocito

LB: medio de cultivo Luria-Bertoni

LCR: Liquido cefaloraquídeo

LIC: $L$. interrogans serovar Copenhageni

LPS: lipopolisacaridos

M: molar

MAT: del ingles microscopic aglutination test

mg: miligramo

min: minutos

ml: mililitro

mm: milímetros

mM: milimolar

ng: nanogramos

nm: nanómetros

mAb: anticuerpo monoclonal

NI: no inducido

nts: nucleotidos

OMS: Organización Mundial de la Salud

OPD: o-phenilediamina dihidrocloreto

ORF: del ingles open reading frame

pb: pares de bases

PBS: buffer fosfato salino 
PCR: reacción en cadena de la polimerasa

PI: posinfección

PM: marcador de peso molecular

p/v: peso en volúmen

PMSF: fluoruro de fenilsulfonilmetilo

R: primer reverso

rP: proteína recombinante purificada

rpm: revoluciones por minuto

RT: transcripción reversa

SDS: dodecil sulfato sódico

SFB: suero fetal bobino

SNC: sistema nervioso central

spp: especie

Ta: temperatura ambiente

Tris: tris (hidroximetil) amino metano

U: unidades enzimáticas, cada enzima posee una defiicion especial segun lo indica el fabricante

vo: via oral

vWF: factor von Willebrand 


\section{Introducción}

\subsection{Espiroquetas}

Las espiroquetas son bacterias de vida parasitaria con forma helicoidal que pueden ser patógenas para humanos y animales. Pertenecen al orden de las Spirochaetales y están divididas en 3 grupos filogenéticos o familias. La familia Spirochaetaceae, incluye a las especies del género Borrelia, Brevinema, Cristispira, Spirochaeta, Spironema, y Treponema. La familia Leptospiraceae incluye a las especies del género Leptonema y Leptospira y por último la familia Brachyspiraceae (=Serpulinaceae) en la cual se encuentran Brachyspira y Serpulina. Las más importantes a nivel médico son Borrelia, Treponema y Leptospira, por ser las causantes de enfermedades importantes que afectan al hombre. Se conocen más de 200 especies o filotipos de espiroquetas, de las cuales más de la mitad no son cultivables (Tabla 1.1)(108).

Tabla 1.1 Algunas características de enfermedades producidas por Espiroquetas

\begin{tabular}{|c|c|c|c|}
\hline Especie & Enfermedad & $\begin{array}{ll}\text { Modo } & \text { de } \\
\text { transmisión } & \end{array}$ & Diagnóstico \\
\hline $\begin{array}{l}\text { Treponema } \\
\text { pallidum }\end{array}$ & Sífilis & $\begin{array}{ll}\text { Sexual } & y \\
\text { transplacentaria } & \end{array}$ & $\begin{array}{l}\text { Microscópico, } \\
\text { test serológico }\end{array}$ \\
\hline $\begin{array}{l}\text { Borrelia } \\
\text { Burgdorferi }\end{array}$ & $\begin{array}{l}\text { Enfermedad de } \\
\text { Lyme }\end{array}$ & $\begin{array}{ll}\text { Mordida } & \text { de } \\
\text { garrapata } & \end{array}$ & $\begin{array}{l}\text { Observación } \\
\text { clínico } \\
\text { microscópica }\end{array}$ \\
\hline $\begin{array}{l}\text { Borrelia } \\
\text { recurrentis }\end{array}$ & $\begin{array}{l}\text { Fiebre } \\
\text { recurrente }\end{array}$ & Mordida de piojo & $\begin{array}{l}\text { Observación } \\
\text { clínico y } \\
\text { microscópica }\end{array}$ \\
\hline $\begin{array}{l}\text { Leptospira } \\
\text { Interrogans }\end{array}$ & Leptospirosis & $\begin{array}{l}\text { Agua y alimentos } \\
\text { contaminados por } \\
\text { orina de animales } \\
\text { infectados } \\
\text { (roedores, ganado) }\end{array}$ & $\begin{array}{l}\text { Test serológico y } \\
\text { cultivo }\end{array}$ \\
\hline
\end{tabular}




\subsection{Leptospiras}

La leptospira es una de las especies del orden de las Spirochaetales, familia Leptospiraceae, género Leptospira. Son células helicoidales flexibles, que miden $0.1 \mu \mathrm{m}$ de diámetro y de 6 a $20 \mu \mathrm{m}$ de longitud, aproximadamente. La morfología de esta bacteria es estrechamente enrollada (Figura 1.1) lo cual se debe a la presencia de unos flagelos especiales denominados filamentos axiales, situados entre la envoltura celular externa y el cilindro protoplasmático (en el espacio periplasmático) que producen un movimiento giratorio que permite a la bacteria entera desplazarse hacia adelante como si fuese un sacacorchos. Los flagelos se insertan por un extremo cerca de cada polo celular, quedando el otro extremo libre el cual está dirigido hacia el centro de la bacteria. Los flagelos son de estructura y composición similar al resto de las bacterias, diferenciándose en que son completamente intracelulares. Presenta sus extremidades incurvadas en forma de gancho, de ahí el nombre de interrogans ya que se asemeja a un signo de interrogación.

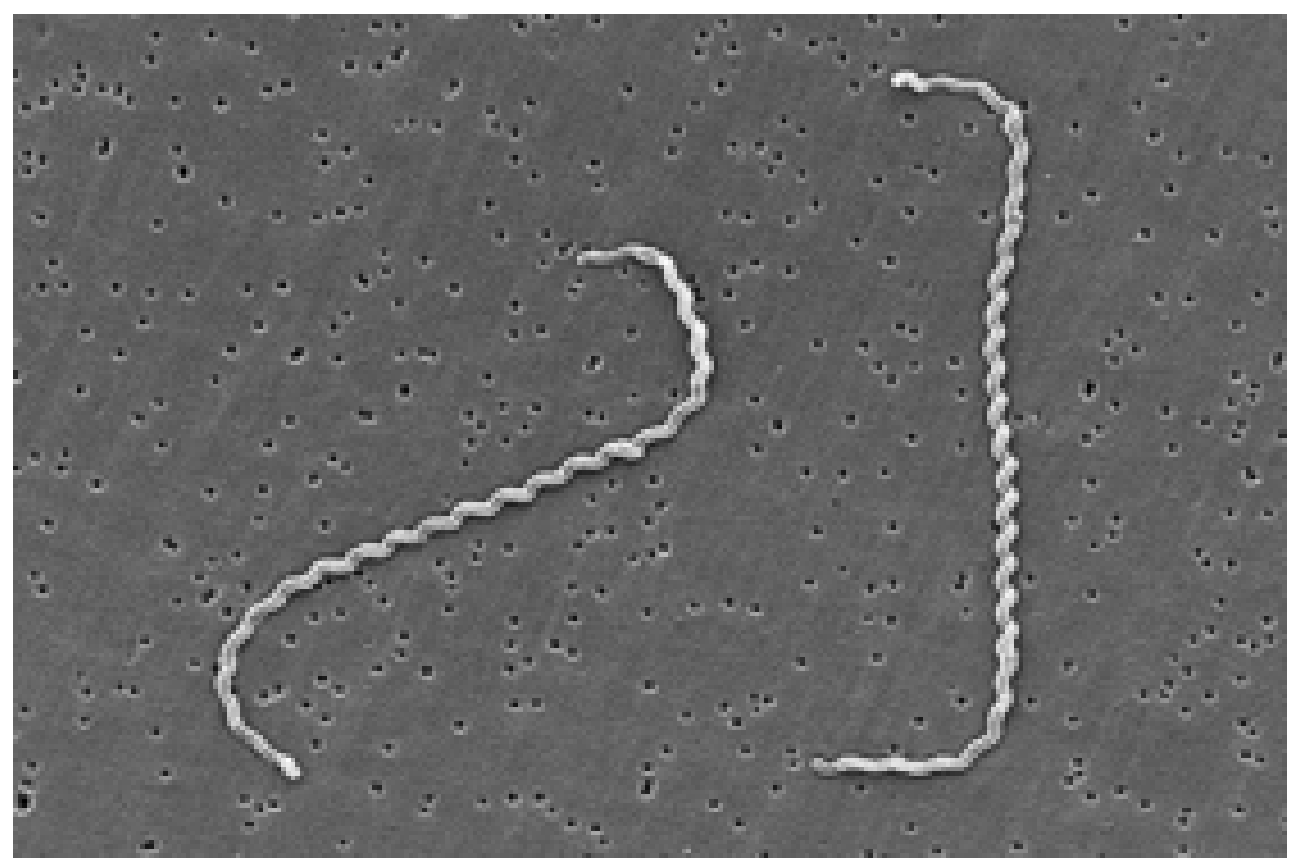

Figura 1.1 Fotografía con microscopio electrónico de barrido de Leptospira spp. Notar la forma en tirabuzón de la bacteria (CDC, Public Health Image Library).

La bacteria tiene una envoltura celular similar a las bacterias Gram negativas, consistiendo en una membrana citoplasmática y otra externa. Sin embargo, la 
capa de peptidoglicano está asociada con la membrana citoplasmática en vez de la membrana externa, algo que es único de las espiroquetas (Figura 1.2). Estas espiroquetas son aeróbicas estrictas, su temperatura óptima de crecimiento es entre 28 y $30{ }^{\circ} \mathrm{C}$, viven por largo tiempo en agua fresca, estiércol, barro y ambientes marinos aunque son fácilmente destruidas por calor, desinfectantes, desecación y acidez. Viven en asociación con huéspedes humanos y animales. La amplia distribución de las especies de Leptospiras, reflejan la habilidad de sobrevivir en diferentes condiciones ambientales, lo que muestra una gran plasticidad genómica que implica una gran capacidad de adaptación (120).

A pesar de poseer la estructura de pared celular característica de las bacterias Gram negativas, se tiñen débilmente por el método de Gram. Para su observación se utilizan técnicas de impregnación argéntica. Debido a que son muy finas poseen escaso contraste al microscopio óptico en fresco, pero se observan claramente al microscopio de campo oscuro (108).

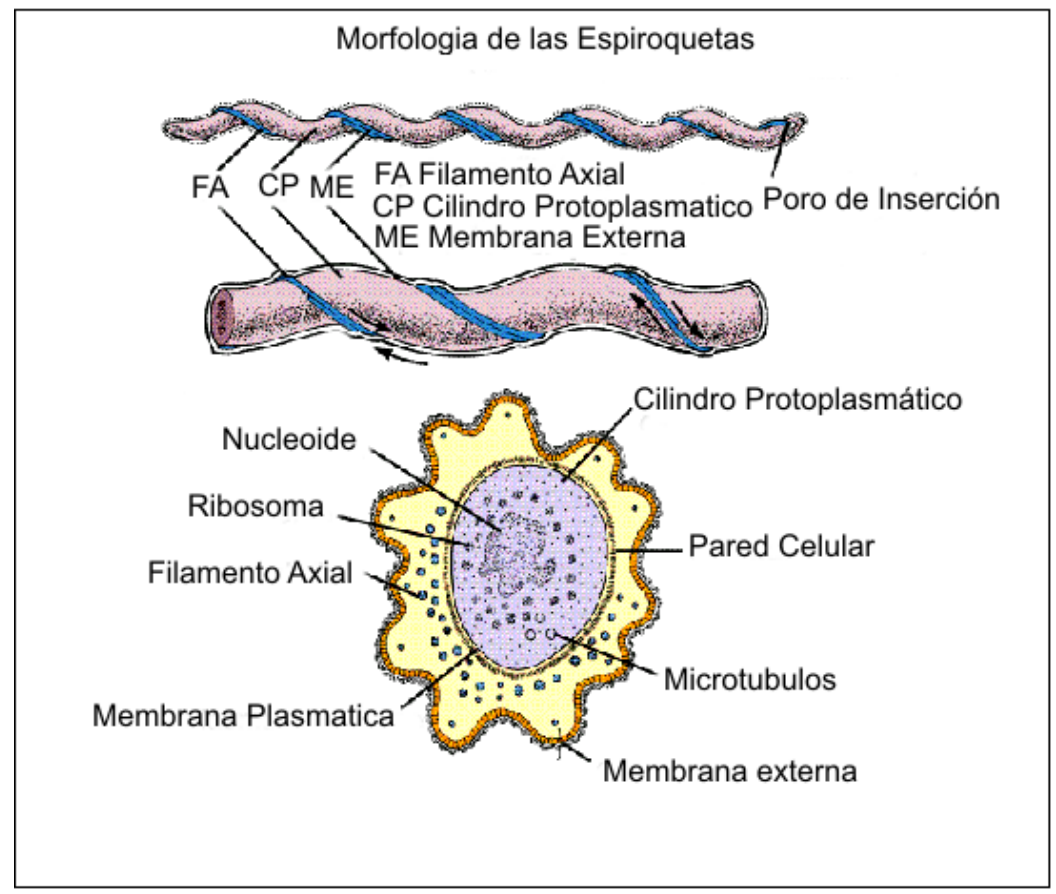

Figura 1.2 Esquema de la morfología de Espiroquetas (Adaptado de Microbiology, 6ta ed., McGraw-Hill).

Hasta hace pocos años, se reconocían dos especies de leptospira, $L$. interrogans y L. biflexa, basándose en la clasificación serológica. La primera es 
patógena para el hombre y para los animales, mientras que la segunda es de vida libre y saprófita. Se han identificado más de 200 variantes serológicas (serovariedades o serovares o subespecies) de $L$. interrogans que se han agrupado por compartir determinantes antigénicos en unos 23 serogrupos (que no constituyen una categoría taxonómica).

Actualmente, y en base a estudios de homología de DNA, patrones de polimorfismo y tipificación de RNA ribosómico, la taxonomía del género Leptospira ha sido reorganizada en las siguientes genoespecies: L. interrogans (sensu estricto), L. biflexa (sensu estricto), L. borgpetersenii, L. weilii, L noguchii, L. santarosai, L. inadai, L. wolbachii, L. meyeri, L. parva, L. kirschneri.

L. fainei, y L. alexanderi. Las genoespecies de Leptospira no se corresponden con la clasificación serológica y, más aún, serovares patógenas y no patógenas se encuentran en la misma especie (108). A menos que se aclare, de aquí en más, se utilizará la clasificación serológica.

\subsection{Leptospirosis}

La leptospirosis, recientemente categorizada como una enfermedad infecciosa emergente, es una zoonosis de distribución mundial de importancia a nivel humano y veterinario que presenta una mayor incidencia en regiones tropicales y subtropicales y es causada por la bacteria Leptospira interrogans (89).

Aunque la leptospirosis en el pasado se había asociado mayormente con individuos cuyo lugar de trabajo o localización geográfica los colocaba en estrecha proximidad de animales salvajes o de cría (27), en el presente está asociada, en el caso de los países desarrollados, con actividades de recreación (outdoors, trekkings, triathlons, etc.) (1), mientras que en los países en vías de desarrollo se ha vuelto prevalente en ciudades donde el rápido crecimiento poblacional, la presencia de villas con viviendas precarias cada vez más grandes, y con medidas sanitarias deficientes, resultan en una población creciente de roedores, animales que actúan como reservorios contaminando el medio ambiente con su orina (70).

La incidencia de la leptospirosis aumenta en épocas de lluvias e inundaciones, cuando ocurre contacto con agua contaminada por leptospiras patogénicas, eliminadas principalmente por la orina de roedores, aunque también puede ser por orina de perros, ganado o cerdos (26). También es considerada una 
enfermedad ocupacional ya que afecta a trabajadores de servicios sanitarios, cloacales, arrozales, bebederos, o aquellos que están en contacto con animales como los veterinarios, entre otros (27).

\subsubsection{Reservorio}

La infección es común en roedores y otros animales tanto domésticos como silvestres. Cada serovar tiene su o sus huéspedes predilectos, pero cada especie puede ser huésped de uno o más serovares (44).

Los reservorios más notables son las ratas (serovar icterohaemorrhagiae), los cerdos (pomona), las vacas (bardjo), los perros (canícola), caballos y caprinos. Otros huéspedes animales en estado de portadores transitorios incluyen a roedores, venados y ciervos, ardillas, zorros, mapaches, mofetas, diversos mamíferos marinos y reptiles (94).

En general, los roedores y animales silvestres no manifiestan síntomas o lesiones. En los animales portadores se produce una infección asintomática a nivel de los túbulos renales que trae como consecuencia que la bacteria se excrete en la orina por un largo período de tiempo (leptospiruria), contaminando así el agua y la tierra. A modo de ejemplo, una vaca puede eliminar $10^{7}$ leptospiras/ml de orina durante varias semanas o meses. Los reservorios más eficaces, desde el punto de vista de la propagación bacteriana, son aquellos animales que tienen leptospiruria prolongada como los roedores $(26,27,108)$. En contraste, la eliminación por orina en el ser humano dura pocas semanas (108)

\subsubsection{Mecanismo de transmisión}

La transmisión de la infección del animal al hombre ocurre tanto por contacto de la piel, especialmente si esta se encuentra erosionada, o de las mucosas, ojos y nariz, con agua, tierra húmeda o vegetación contaminadas con la orina de animales infectados (Figura 1.3). Este contagio puede ocurrir al nadar o inmersión accidental, por contacto directo con la orina o tejido de animales infectados en excoriaciones que pueden ser ocupacionales, o a veces, por la ingestión de alimentos contaminados con orina de ratas infectadas. Rara vez se produce por inhalación de gotitas en aerosol de líquidos contaminados. En esta enfermedad es rara la transmisión directa de persona a persona $(66,108)$. 
Figura 1.3 Ciclo de transmisión de la leptospirosis. El ser humano ocupa un eslabón terminal.

\subsubsection{Prevalencia e incidencia en la República Argentina}

En la República Argentina, la incidencia en la población humana ronda el 18\% de positividad serológica frente a Leptospira spp cuando se evalúan sueros de pacientes sospechosos. Mientras que en pacientes no sospechosos, el porcentaje varía entre el 2 y el 6\%. Aproximadamente, el $28 \%$ de los casos clínicos detectados corresponde a áreas densamente pobladas, lo que la 
clasifica como una importante zoonosis urbana de notificación obligatoria que puede presentarse tanto en forma esporádica como en brotes epidémicos (93, 108).

\subsubsection{Historia Natural}

El período de incubación es de alrededor de 10 días, con límites de 4 a 19 días. Permanece largamente subdiagnosticada en parte debido al gran espectro de signos y síntomas que los pacientes pueden presentar $(47,89)$.

Si bien suele ser autolimitada y sin secuelas, desafortunadamente entre un 5 y un $15 \%$ de los casos evolucionan de forma más severa, con una tasa de mortalidad que puede ir en estos casos desde un 5 a un 40\%, presentando hemorragias y fallas renales y/o hepáticas, lo que se conoce como Síndrome de Weil (26). En los últimos años, ha sido cada vez más frecuente el compromiso pulmonar $(113,114)$

En el curso natural de la leptospirosis se distinguen 2 fases: septicémica e inmune (Figura 1.4). Durante un período breve de 1 a 3 días entre las 2 fases el paciente presenta alguna mejoría.

Figura 1.4 Naturaleza bifásica de la leptospirosis y sus características en la enfermedad en diferentes estadios. La serología 1 y 2 representan la fase aguda de la enfermedad, 3 la fase convaleciente lo que facilita la detección de 
la respuesta inmune y 4 y 5 son seguimientos de muestras que pueden tener valor (Adaptado de Turner, L.H. Leptospirosis i: 231-235, 1969).

Primer estadío: esta fase es denominada septicémica o leptospirémica porque la leptospira puede ser aislada de cultivos a partir de sangre, líquido cefalorraquídeo (LCR) y otros tejidos. En esta etapa, que dura de 4 a 7 días, el paciente desarrolla una enfermedad no específica parecida a una gripe de variada intensidad. Se caracteriza por fiebre, escalofríos, debilidad, y mialgias, afectando primariamente las pantorrillas, espalda y abdomen (38). Otros síntomas pueden ser dolor al tragar, tos, dolor en el pecho, erupción, hemoptisis, jaqueca, confusión mental, fotofobia, y otros síntomas del síndrome meníngeo. Con frecuencia, el paciente puede referir exactamente cuando fué el comienzo, ya que en esta enfermedad es característico el comienzo abrupto de los síntomas.

Entre ambos estadios hay un breve lapso que dura de 1 a 3 días donde el paciente presenta mejoría con descenso de la temperatura pudiendo estar asintomático. Luego la fiebre retorna indicando el comienzo de la segunda fase cuando se presenta una meningitis clínica o subclínica.

Segundo estadío: esta fase es denominada inmune o leptospirúrica porque se pueden detectar anticuerpos circulantes o el microorganismo puede ser aislado de la orina y ya no de la sangre o del LCR. Esta etapa ocurre como consecuencia de la respuesta inmune del huésped y puede durar de 1 a 30 días o más. La enfermedad ahora está referida a la afección de órganos específicos, incluyendo meninges, hígado, ojos y riñón. Síntomas no específicos como fiebre y mialgia son menos severos que en la primera fase y pueden durar de días a semanas. Alrededor del $75 \%$ de los pacientes experimentan jaquecas que no ceden ante analgésicos y que con frecuencia anticipa el comienzo de una meningitis.

Aquí la enfermedad puede tomar dos presentaciones: anictérica o ictérica. En la primera la meningitis aséptica es el síndrome clínico más importante usualmente dura pocos días pero puede persistir hasta 1 o 2 semanas. Los síntomas no son específicos y puede sospecharse una meningitis viral. Encefalitis y/o cambios en la conciencia son menos frecuentes. Los síntomas meníngeos se presentan en el $50 \%$ de los pacientes y la muerte es extremadamente rara en la presentación anictérica de la enfermedad. 
En la presentación ictérica de la enfermedad las leptospiras pueden ser aisladas de la sangre entre 24 y 48 horas luego del comienzo de la ictericia. Puede ser acompañada por dolor abdominal, diarrea, constipación, hepatoesplenomegalia, nauseas, vómitos y pérdida del apetito. Entre un 2 y un $10 \%$ de los casos pueden presentar otras complicaciones como uveítis, que puede ocurrir concomitantemente con la enfermedad o hasta 1 año después (80). La iridociclitis y la coriorretinitis pueden ser complicaciones que pueden persistir por años. Sin embargo, la hemorragia subconjuntival es la complicación oftalmológica más frecuente de la leptospirosis, ocurriendo en el $92 \%$ de los pacientes. Las leptospiras pueden estar presentes en el humor acuoso.

Los síntomas renales tales como azotemia, piuria, hematuria, proteinuria, y oliguria están presentes en el $50 \%$ de los pacientes con leptospirosis. Las leptospiras pueden estar presentes en el riñón. Las manifestaciones pulmonares pueden ocurrir entre el 20 y el $70 \%$ de los pacientes (63). En los últimos años el porcentaje de compromiso pulmonar parece haber aumentado en particular en su forma hemorrágica (101). También pueden observarse adenopatías, erupciones y dolor muscular.

Aunque no existe correlación entre síndromes clínicos y serotipos involucrados, se ha observado que la ictericia está presente en el $83 \%$ de los pacientes infectados con $L$ icterohaemorrhagiae y en el $30 \%$ de los pacientes infectados con $L$ pomona. Una erupción eritematosa pretibial puede ser observada en pacientes infectados con $L$ autumnalis. En forma similar, los síntomas gastrointestinales predominan en pacientes infectados con $L$ grippotyphosa. La meningitis aséptica ocurre más frecuentemente en pacientes infectados con $L$ pomona o $L$ canicola (37).

La leptospirosis puede presentarse como una erupción macular o maculopapular, con dolor abdominal mimetizando una apendicitis aguda, o como adenopatía generalizada simulando una mononucleosis infecciosa. Otras presentaciones incluyen meningitis aséptica, encefalitis, o fiebre de origen desconocido.

La leptospirosis debe considerarse en un paciente que presenta una enfermedad parecida a una gripe, con meningitis aséptica y mialgia. 


\subsubsection{Síndrome de Weil}

Esta forma severa de leptospirosis se manifiesta primariamente como ictericia, con disfunción renal, necrosis hepática, disfunción pulmonar y diátesis hemorrágica (58). Suele presentarse al final de la primera fase y se agudiza durante la segunda fase aunque la condición del paciente puede deteriorarse súbitamente en cualquier momento siendo la transición entre fases poco marcada. No existen criterios para anticipar quien desarrollará Síndrome de Weil. Las manifestaciones respiratorias incluyen tos, disnea, dolor torácico, hemoptisis y fallo respiratorio. Las disfunciones vasculares y renales acompañadas por ictericia se desarrollan de 4 a 9 días luego del comienzo de la enfermedad y la ictericia puede durar semanas. Los pacientes con severa ictericia son más propensos a desarrollar fallo renal, hemorragia y colapso cardiovascular (24). Puede existir hepatomegalia y necrosis tubular aguda con oliguria o anuria durante la segunda semana debido a la hipovolemia y la disminución de la perfusión renal. También puede presentarse fallo multiorgánico, rabdomiólisis (111), síndrome de dificultad respiratoria del adulto (16), hemólisis, esplenomegalia, insuficiencia cardíaca congestiva, miocarditis y/o pericarditis (50). El síndrome de Weil posee una tasa de mortalidad del 5 al $10 \%$ de los casos. En los casos severos, con compromiso hepatorenal e ictericia, la tasa se acerca al 40\%, especialmente en pacientes mayores.

\subsubsection{Datos de laboratorio}

En la presentación moderada, puede observarse una elevada tasa de sedimentación y leucocitosis periférica (3.000-26.000 x mL) con desvío a la izquierda. Las aminotransferasas, la bilirrubina sérica y la fosfatasa alcalina pueden encontrarse elevadas. En el examen de orina puede observarse proteinuria, leucocitos, eritrocitos y cilindros hialinos y granulares. Cuando existe compromiso del Sistema Nervioso Central (SNC), el LCR puede presentar inicialmente leucocitos polimorfonucleares que son reemplazados más tardíamente por monocitos. El contenido de proteína puede ser normal o estar elevado, mientras que los niveles de glucosa y la presión sanguínea son normales.

En el Síndrome de Weil los pacientes pueden presentar: trombocitopenia, frecuentemente acompañada por fallo renal; azotemia; marcada leucocitosis; 
elevación del tiempo de protrombina; elevación de la creatina fosfoquinasa (CPK) con elevación moderada de las transaminasas y anormalidades del electrocardiograma (ECG); en casos severos puede ocurrir insuficiencia cardíaca congestiva y shock cardiogénico.

\subsubsection{Respuesta inmune}

La respuesta humoral, en especial la IgM específica puede ser detectable por MAT (microscopic aglutination test, ver más adelante) a partir de los 5-7 días posinfección ( $\mathrm{PI})$, elevándose a su máximo en las siguientes semanas, permaneciendo de meses a años y puede ser afectada por el tratamiento. Como determinante antigénico se destaca el lipopolisacarido leptospiral, y otros componentes de la membrana (ver más adelante). La producción de IgG es inconstante. La especificidad de las $\mathrm{lg}$ es generalmente de serovar. La fagocitosis por polimorfonucleares sería más lenta comparada con otras bacterias como E. coli.

\subsubsection{Patogénesis}

Luego de ingresar por piel o mucosas, el organismo se multiplica en la sangre y los tejidos. La resultante leptospiremia puede diseminarse a cualquier parte del cuerpo aunque afecta particularmente al hígado, los riñones y el pulmón.

A nivel renal, el microorganismo migra al intersticio, túbulos renales y luz tubular causando nefritis intersticial y necrosis tubular. Si existe fallo renal, este se debe generalmente al daño tubular, aunque también contribuyen la hipovolemia resultante de la deshidratación y la alterada permeabilidad capilar. Cuando existe compromiso hepático, suele observarse como una necrosis centrolobular con proliferación de células de Kupffer. La ictericia puede resultar de la disfunción hepatocelular. Las leptospiras también pueden invadir el músculo esquelético, causando edema, vacuolización de miofibrillas y necrosis focal. La microcirculación del musculo esquelético es afectada y la permeabilidad capilar es incrementada, resultando en perdida de fluido e hipovolemia. En casos severos, puede presentarse un síndrome de vasculitis diseminada como resultado del daño al endotelio capilar. Las leptospiras pueden invadir el humor acuoso ocular, donde pueden persistir durante meses, ocasionalmente conduciendo a uveítis crónica o recurrente. 
Aun considerando las posibles severas complicaciones, la enfermedad es frecuentemente autolimitada y no fatal (107). La respuesta inmune sistémica puede eliminar al microorganismo del cuerpo, pero también puede conducir a una reacción inflamatoria que produzca injuria tisular secundaria (61).

\subsubsection{Diagnóstico}

La leptospirosis es una enfermedad de difícil diagnóstico clínico, ya que son frecuentes las enfermedades con síntomas similares a ella. Es necesaria una buena anamnesis que abarque los antecedentes personales de 15 a 20 días anteriores a la presentación de la enfermedad.

El diagnóstico de leptospirosis se realiza frecuentemente utilizando una combinación de evidencias clínicas, pruebas de laboratorio y las características epidemiológicas como ser: locación, temporada, lugar de trabajo, hábitat, contacto con animales, viajes a áreas endémicas, etc. Los síntomas más característicos para un diagnóstico temprano son: fiebre abrupta, dolores musculares, malestar general, eritrosedimentación elevada y la presencia de leucocitos y neutrófilos en orina.

Ocasionalmente por el aislamiento de leptospira en la sangre (las leptospiras permanecen viables en sangre anticoagulada hasta 11 días; las muestras deben ser enviadas a un laboratorio de referencia para su cultivo) en los primeros 7 días (una vez que el sistema inmune es activado, los cultivos a partir de sangre pueden volverse negativos) o en el LCR (del $4^{\circ}$ al $10^{\circ}$ día) durante la fase aguda de la enfermedad, y en la orina, se pueden aislar después del $10^{\circ}$ día por semanas, inclusive meses o años. Los cultivos de orina positivos pueden tomar hasta 8 semanas para crecer. Actualmente, se utilizan las técnicas de inmunofluorescencia indirecta y ELISA para detectar las leptospira en muestras clínicas y de necropsia (106).

\subsubsection{Pruebas serológicas}

El diagnóstico positivo se realiza por una elevación de 4 veces en los títulos de las pruebas serológicas, como el test de aglutinación microscópica (MAT). Un diagnóstico presuntivo puede realizarse cuando el título de anticuerpo es igual o mayor a 1:100 en el MAT en conjunto con síntomas consistentes con la enfermedad. En el MAT se utilizan una batería de 5 a 20 cepas de leptospiras 
más frecuentes vivas en ese lugar, se incuban con sueros a testar a fin de detectar anticuerpos aglutinantes. La información derivada de este ensayo es frecuentemente utilizada para identificar el serovar o variante de la leptospira patógena; sin embargo, son comunes las reacciones paradójicas y cruzadas entre serovares (67). Otros tests incluyen la hemaglutinación indirecta, el test de aglutinación microcapsular, detección de IgM específica por enzyme-linked immunoabsorbent assay (ELISA), y la examinación de sangre u orina por campo oscuro. Más recientemente, se encuentran también disponibles test comerciales rápidos como el Dip-S-Ticks (PanBio, Maryland, USA), que detectan anticuerpos antileptospira. EI ELISA, al detectar IgM, puede ser útil para el diagnóstico de nuevas infecciones dentro de los 3 a 5 primeros días. Solo laboratorios especializados realizan el MAT, no debiendo retrasar el tratamiento, que se deberá comenzar mientras se esperan los resultados. Más recientemente y en forma creciente, algunos protocolos de PCR se han propuesto para el diagnóstico y la identificación serotípica $(7,86,87)$.

\subsubsection{Diagnóstico diferencial}

Debe hacerse con dengue, influenza, hepatitis vírica, fiebre hemorrágica viral, septicemia con ictericia o una variedad de enfermedades semejantes localmente prevalentes, incluyendo diversas enfermedades eruptivas, paludismo, fiebre de origen desconocido, rickettsiosis (fiebre Q, tifus), borreliosis, brucelosis, toxoplasmosis, pielonefritis y fiebre amarilla. En pacientes que presentan meningitis debe hacerse un diagnóstico diferencial para establecer el origen viral o bacteriano (25).

\subsubsection{Tratamiento}

En general, el tratamiento es bajo internación hospitalaria. La hidratación parenteral es la base del tratamiento en especial en pacientes con shock donde la rehidratación debe ser agresiva y la deshidratación debe ser corregida en 6 a 24 horas. La reposición de fluidos debe continuar hasta que los niveles diuréticos son corregidos. La orina producida por un paciente sospechoso de leptospirosis deberá ser coleccionada y considerada de riesgo biológico. Otras medidas incluyen control de signos vitales, monitoreo de la oximetría (valoración de la saturación de oxígeno), rayos $x$, que permite en casos 
severos, observar en radiografías pulmonares un patrón alveolar punteado en general en la periferia de los lóbulos inferiores que corresponde a hemorragia pulmonar, laboratorio de función renal y hepática y administración de antibióticos. En este caso, según el siguiente esquema para casos pediátricos: Penicilina G 250.000 U/Kg/día por vía intravenosa (IV) fraccionado en cuatro dosis (cada 6 horas) durante 7 a 10 días. Tetraciclina en mayores de 9 años 40 $\mathrm{mg} / \mathrm{Kg} / \mathrm{día}$, cada 6 horas VO por 7 a 10 días. En casos de adultos: Penicilina sódica, 2 a 4 millones U cada 6 horas IV por 7 días (droga de elección). Para aquellos alérgicos a la penicilina: Cefotaxina de 1 a 2 gr. cada 8 horas por 7 días IV o IM. Tetraciclina 500 mg cada 6 horas por 7 días VO. Doxiciclina 100 mg 2 veces al día VO por 7 días. Otros esquemas también son empleados.

\subsubsection{Pronóstico}

La mayoría de los pacientes se recupera aún sin tratamiento. La tasa de mortalidad más alta se observa en pacientes ancianos y/o en aquellos que desarrollan Síndrome de Weil. Las mujeres embarazadas presentan una alta tasa de mortalidad fetal o abortos espontáneos, en especial si la infección se contrajo durante los primeros meses de embarazo. Si sobreviven, los pacientes con disfunción hepática y falla renal, tienen altas chances de recobrar sus funciones normales hepáticas y renales en el largo plazo.

\subsubsection{Profilaxis}

La doxiciclina, en dosis de $200 \mathrm{mg} / \mathrm{semana}$, ha demostrado ser eficaz en el 95\% de los casos de leptospirosis y puede ser administrada para prevenir la enfermedad en aquellas personas que han sido expuestas (60).

Las vacunas de uso veterinario disponibles actualmente están basadas en preparaciones totales de membrana inactivada de leptospiras patogénicas y parecen inducir una respuesta protectora a través de la inducción de anticuerpos antilipopolisacáridos de leptospira $(26,66)$. Sin embargo, estas vacunas fallan en inducir una protección de largo plazo y en proveer inmunidad protectora cruzada contra serotipos de leptospira no incluidos en la preparación vacunal. El gran número de serotipos patogénicos (>200) y el costo de producir una vacuna que contenga componentes de múltiples serotipos han sido factores limitantes mayores en el desarrollo de protocolos de inmunización 
basados en célula entera o en preparaciones de membrana. Las mismas limitaciones ocurren a la hora de desarrollar una vacuna licenciada para uso humano sumado a las reacciones adversas por emplear preparaciones totales de membrana $(3,25,59)$. No existe una vacuna licenciada de uso humano ni tampoco existen vacunas de uso veterinario basadas en antígenos recombinantes, es decir, altamente homogéneos, confiables y eficaces, por lo que cabe inferir que dichos productos tendrían una demanda importante de parte del mercado local e internacional y por lo tanto servirían para generar patentes de alto impacto económico (59).

\subsubsection{Medidas de control}

Entre la medidas de control pueden mencionarse la notificación de todos los casos a la autoridad correspondiente; el aislamiento del paciente y precauciones respecto a la sangre y los líquidos corporales de las personas enfermas; la desinfección concurrente de los artículos contaminados con orina; la investigación de todos los casos, contactos y de la probable fuente de infección.

\subsubsection{Vigilancia epidemiológica}

Es una enfermedad que probablemente se pasa por alto y por ende esta subnotificada en muchos países, debido al difícil diagnóstico clínico y a la falta de laboratorios de diagnóstico. La OMS recomienda la inmediata notificación de casos sospechosos o confirmados a nivel periférico (en hospitales o laboratorios), debiéndose investigar todos los casos. La vigilancia con base en hospitales permite obtener así información sobre los casos más graves. La serovigilancia indica las variedades prevalentes.

La definición de caso recomendada corresponde a enfermedad febril aguda con cefalea, mialgia y postración asociada a: subfusión conjuntival, irritación meníngea, anuria/oliguria/ y/o proteinuria, ictericia, hemorragias (intestinal, pulmonar), arritmias o insuficiencia cardíaca, erupción cutánea y el antecedente de exposición a animales infectados o a un ambiente contaminado con orina de animales. El criterio recomendado para dar a un caso confirmado como positivo corresponde a aquel que es confirmado por un laboratorio competente, mediante aislamiento o serología positiva. 


\subsubsection{Impacto socio-económico}

La leptospirosis es un problema económico mayor para la salud pública así como para la industria agropecuaria, ya que en los pacientes el tratamiento requiere hospitalización y no infrecuentemente diálisis renal (57), mientras que en el ganado induce abortos, partos prematuros, infertilidad, reducción de la producción de leche, pérdida de peso y hasta muerte (26).

Como la leptospirosis produce en el ganado una infección crónica, la industria agropecuaria sufre una pérdida económica adicional cuando se aplican a nivel nacional y/o internacional regulaciones de cuarentena.

Porque tiene una correlación directa con la situación económica y porque afecta a países agroexportadores, no sorprende que tenga un impacto mayor en un país como la Argentina.

\subsection{Búsqueda de antígenos recombinantes útiles en diagnóstico o prevención}

El advenimiento del secuenciamento completo de los genomas ha tenido un impacto enorme en el campo de la Microbiología. El secuenciamento completo del genoma del serogrupo B de Neisseria meningitidis representó una nueva estrategia para la identificación de candidatos vacunales finalizando con 4 décadas de esfuerzo continuo utilizando técnicas convencionales (88). Esta aproximación histórica, denominada ahora reverse vaccinology, ha sido aplicada en los últimos 3 años y ha revolucionado el área de investigación en vacunas, ya que ha permitido el diseño de vacunas comenzando con la predicción de todos los antígenos in silico, independientemente de su abundancia y sin la necesidad de crecer el microorganismo in vitro $(2,76,96)$.

El genoma de Leptospira interrogans serotipo Copenhageni, LIC, fue totalmente secuenciado por el Consorcio AEG-Agronomical \& Environmental Genomes/ONSA/FAPESP, bajo la coordinación general de la Dra. Ana Lucia Tabet Oller do Nascimento (Centro de Biotecnología Molecular, Instituto Butantán). Las secuencias han sido depositadas en el GenBank bajo los números de acceso AE016823 (cromosoma I) y AE016824 (cromosoma II). El genoma de Leptospira consiste en 2 cromosomas circulares con un total de 4,627,366 pares de bases (bp), correspondiendo al cromosoma I 4,277,185 bp y al cromosoma II 350,181 bp (Figura 1.5). 


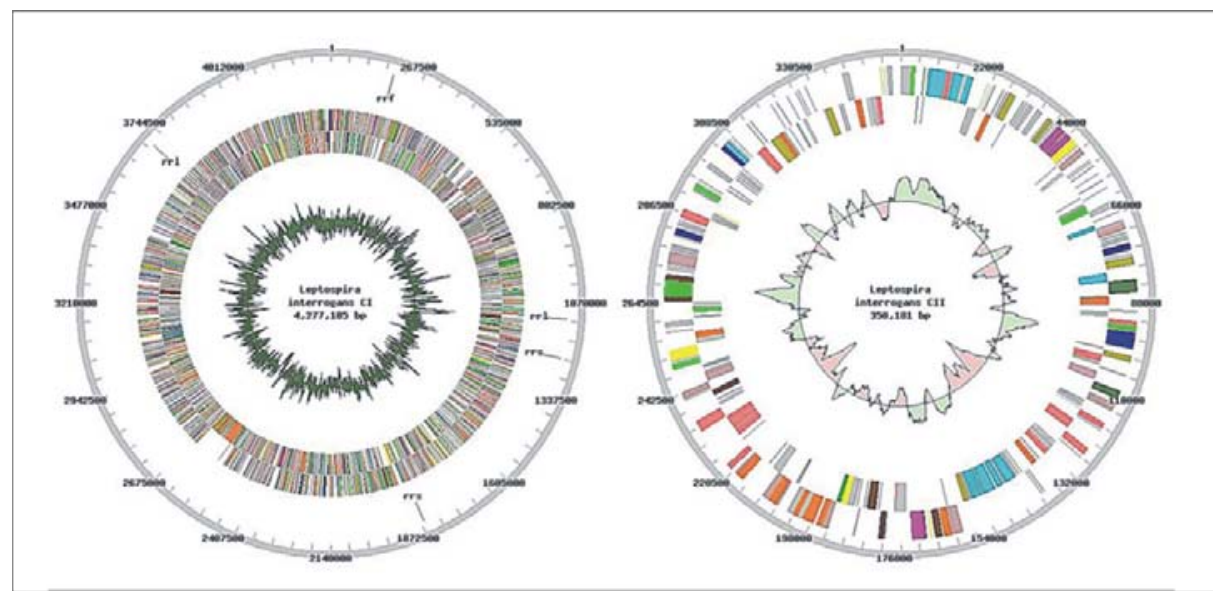

Figura 1.5 Mapa circular de los 2 cromosomas en Leptospira interrogans.

El genoma de leptospira contiene un amplio abanico de genes codificantes incluyendo aquellos de sistemas regulatorios, señales de transducción, y proteínas quimiotácticas, que reflejan la habilidad de este organismo a responder a diversos estímulos del entorno. La identificación de un conjunto completo de genes codificadores de enzimas para la vía biosintética de la cobalamina así como los genes relacionados con la biosíntesis de lipopolisacáridos generan fundadas expectativas de clarificar el estudio fisiológico de las bacterias comprendidas en el género Leptospira. Otros genes relacionados a toxinas, lipoproteínas y varias proteínas expuestas en la superficie podrán facilitar una mayor comprensión de los mecanismos patogénicos involucrados en las enfermedades que estas bacterias producen y podrán servir como potenciales candidatos a la hora de desarrollar productos tanto para el diagnóstico como la prevención (84). Independientemente, el genoma de la Leptospira interrogans serotipo Lai fué también secuenciado completamente (92). Un análisis comparativo de ambos genomas ha sido publicado (83).

\subsubsection{Justificación de los candidatos seleccionados}

La lesión principal en la leptospirosis se relaciona con el daño producido en los capilares y pequeños vasos (26). Algunos investigadores creen que una 0 varias toxinas bacterianas podrían jugar un papel importante en la progresión de la enfermedad. Varias proteínas fueron identificadas como potenciales 
candidatos vacunales, y algunas de ellas están relacionadas con la patogénesis de la enfermedad (35). Genes que codifican para colagenasas, metaloproteasas y termolisinas fueron identificados como lipoproteínas. En LIC también se encontraron genes que codifican para adhesinas, con dominios similares tanto a inmunoglobulinas como a integrinas. En este sentido, un amplio rango de moléculas celulares puede funcionar como receptores para la adhesión de la bacteria al huésped $(10,30,55)$. Las proteínas de superficie se consideran como el primer contacto por el cual el microorganismo interactúa y se adhiere a los tejidos del huésped. Esta unión parece ser un primer estadío esencial en el establecimiento de la infección de varios patógenos bacterianos. Las moléculas de adhesión o CAMs (del inglés cell adhesion molecules) son receptores celulares de superficie presentes en células eucariotas que median las interacciones célula-célula o célula-matriz extracelular. Un número significativo de bacterias patógenas invaden los tejidos del huésped a través de su habilidad de unirse a las CAMs $(10,30)$. Además del esperado efecto del lipopolisacárido de la pared, se ha observado la activación del endotelio vascular por proteínas de espiroquetas que resultan en una aumentada expresión de receptores de adhesión. Diversos estudios con las espiroquetas patogénicas Borrelia spp y Treponema spp, han reportado la estimulación del endotelio vascular in vitro que conducen a un aumento en la expresión de CAMs $(62,64,103-105)$. El análisis del genoma de LIC revela 263 potenciales proteínas de membrana expuestas en la superficie $(83,84)$, aunque a la fecha, solo unas pocas han sido caracterizadas a nivel molecular. Estos productos de genes desconocidos son potenciales candidatos en mediar la interacción con células del huésped, facilitando la colonización de tejidos y por lo tanto siendo importantes primeros pasos en el proceso infeccioso.

Las lipoproteínas son actualmente consideradas de gran interés en la búsqueda de candidatos vacunales y marcadores diagnósticos (40). Algunas lipoproteínas de espiroquetas ya han sido aisladas y estudiadas como OspA de Borrelia burgdorferi (15), SmpA de Brachyspira hiodysenteriae (109), LipL32 de Leptospira interrogans (40) y Tpp47 de Treponema pallidum (115). Existe en la actualidad una vacuna licenciada en los EUA que utiliza la lipoproteína OspA para prevenir la enfermedad de Lyme causada por la espiroqueta Borrelia burgdorferi (90). Además, las lipoproteínas pueden activar al sistema inmune 
innato a través de receptores Toll-like (119). Haake y col (42) demostraron sinergismo en la protección de animales contra leptospirosis utilizando 2 proteínas externas, OmpL1 y LipL41. Otros estudios mostraron que el suero de pacientes convalecientes reaccionaban con LipL32, LipL41 y otras 2 proteínas de 62 y $76 \mathrm{kDa}$ identificadas como proteínas de choque térmico (39). Se ha sugerido que estas proteínas podrían servir como marcadores diagnósticos. Recientemente, una lipoproteína nueva, LpL21, fue identificada en diversas especies de leptospiras patogénicas (20). En conjunto, estos datos indican que las lipoproteínas de LIC son de gran importancia como candidatos vacunales y marcadores diagnósticos.

En la secuenciación del genoma de LIC se han identificado 184 lipoproteínas, siendo conocidas al momento de comenzar este estudio, solo poco más de 10. Entre las 174 lipoproteínas nuevas, muchas son hipotéticas, es decir que no se han identificado en otro organismo. El análisis bioinformático procuró, entre otros, la presencia de un lipobox, es decir una secuencia consenso que en espiroquetas es diferente de las de E. coli (117). La secuencia consenso fue determinada por alineado de lipoproteínas de B. burgdorferi (33), T. pallidum (34) y Leptospira (40).

En las espiroquetas, el lipobox es representado por la siguiente secuencia:

Leu(Ala,Ser)--4eu(Val,Phe,Ile)-3-Ile(Val,Gly)-2-Ala(Ser,Gly) ${ }_{-1}-C_{-1} s_{+1 .}$

Las lipoproteínas seleccionadas en este trabajo son LIC10365 y LIC11352 (Tabla 1.2).

Tabla 1.2 Genes seleccionados de LIC. El software utilizado para la predicción de la secuencia del péptido señal: Psort (http://psort.nibb.ac.jp/) y Smart (http://smart.embl-heidelberg.de/).

\begin{tabular}{|l|l|l|l|l|l|}
\hline Gen & Similaridad & nts & aa & Masa molecular & Péptido señal \\
\hline LIC10365 & $\begin{array}{l}\text { Lipoproteína } \\
\text { hipotética }\end{array}$ & 1080 & 359 & $\begin{array}{l}37.7 \mathrm{kDa} \\
\text { (rLIC10365) }\end{array}$ & $1-19$ (Smart) \\
\hline LIC11352 & LipL32 & 819 & 273 & $29.6 \mathrm{kDa}$ & $1-23$ (Psort) \\
\hline
\end{tabular}


Varios genes codificantes para potenciales lipoproteínas de membrana identificados en el genoma de Leptospira podrían ser responsables de las alteraciones microvasculares observadas durante la infección. Uno de ellos, el gen LIC10365, será incluido en este estudio ya que presenta homología con condroitinasa $\mathrm{B}$ y con pertactina, un factor de virulencia de Bordetella utilizado como inmunógeno en la producción de vacunas experimentales acelulares contra pertussis.

Con respecto a LipL32, corresponde a una proteína ubicua con actividad hemolítica cuando es expresada tanto in vitro como in vivo (19, 40). Es reconocida por anticuerpos durante la fase humoral y por lo tanto resulta un posible marcador diagnóstico (39). Además, brinda protección parcial en modelo animal y por lo tanto podría ser una subunidad en una vacuna recombinante (11).

\subsection{Toxina colérica y su utilidad como adyuvante}

La toxina colérica pertenece a la familia de toxinas del tipo AB5, junto con la enterotoxina de E. coli (LT) (73).

Se las denomina así porque están formadas por dos subunidades en una relación 1:5. La subunidad $A$ (con actividad tóxica) y un pentámero formado por las subunidades $B$ que se unen a un sitio específico del huésped trasladando selectivamente a la subunidad $A$.

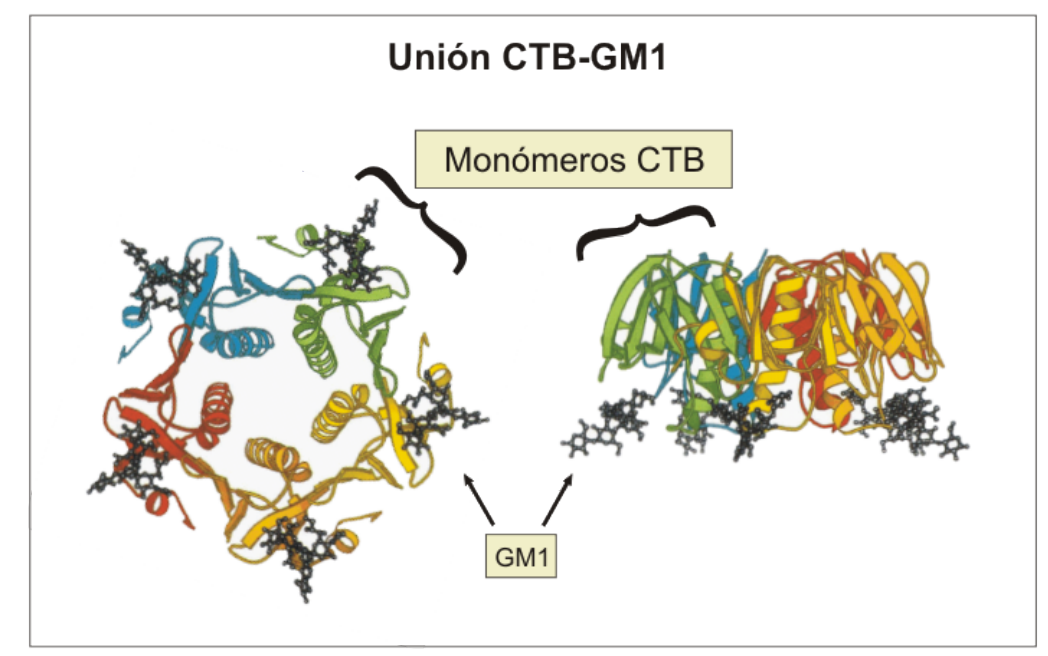

Figura 1.6 Esquema del pentámero conformado por la subunidad B de la toxina colérica y su interacción con el receptor celular GM1. 
Estas toxinas explotan el mecanismo de tráfico celular del huésped para tener acceso al citosol (65) donde muestran su actividad tóxica (49). Luego de ser liberada por la bacteria en el yeyuno, la toxina reconoce en la superficie epitelial al gangliósido GM1 a través de la subunidad B (Figura 1.6)(29, 56). Subsecuentemente, la toxina es internalizada en vesículas y transportada al Golgi (8), donde se separa la subunidad A por reducción de un puente disulfuro (54). La subunidad A sigue una ruta retrógrada por el retículo endoplasmático (8) y es translocada al citosol por la ruta de degradación de proteínas asociadas al retículo endoplásmico (46). En el citosol produce la irreversible ADP ribosilación de GsR logrando la activación de la Adenilato Ciclasa (79). La alta concentración de AMP cíclico inhibe la reabsorción de sodio y activa la secreción de cloruro (28), resultando en una masiva liberación de fluidos desde las células intestinales.

El pentámero formado por las subunidades B es capaz de reconocer a la célula blanco y unirse a ella en ausencia de la subunidad $A$, generando una respuesta inmune eficiente en la mucosa, lo que permite su uso como transportador para obtener anticuerpos contra antígenos unidos a este, ya sean conjugaciones genéticas o químicas. En cambio posee un relativamente bajo poder como adyuvante de moléculas coadministradas junto a esta $(21,51,68,71)$.

Se ha demostrado que CTB es un potente inmuno estimulador y que la expresión de polipéptidos de fusión con CTB permite la reducción de hasta 10.000 veces la dosis de inmunógeno necesaria para lograr una determinada respuesta inmune (36). El mecanismo por el cual CTB es eficaz como transportador de moléculas no está bien definido pero se cree que está asociado con la fuerte unión de CTB con su receptor, el gangliósido GM1.

GM1 es un gangliósido lipídico presente en muchas células incluyendo aquellas del lumen intestinal. Cada monómero de la subunidad B tiene la capacidad de unirse a una unidad de GM1 produciendo un complejo toxina-gangliósido (Figura 1.7). Esta unión es altamente específica y cooperativa (99). La estabilidad del pentámero depende de la cooperación entre las subunidades. 
Figura 1.7. Esquema de la conformación del gangliósido GM1.

Si bien la función normal del gangliósido es poco conocida se lo ha implicado en varias rutas de transducción de señales. Por ejemplo, GM1 exógeno afecta a la señalización de Ca2+ (48), a la modulación de la expresión de CD4 (77, 78), y a la modulación de la activación de la proteína tirosina kinasa del factor de crecimiento epidérmico (116). Se ha visto que CTB interfiere con, o potencia los efectos de, varios factores de crecimiento. 


\subsection{Objetivos específicos}

El presente trabajo consta de 2 capítulos.

El primer capítulo describe:

- el clonado, la expresión y la purificación de la proteína LIC10365;

- la producción de antisuero contra la proteína recombinante;

- el análisis del grado de conservación y expresión de LIC10365 entre diferentes serotipos de leptospira;

- el estudio de su expresión durante la infección in vivo;

- el estudio de su capacidad para activar a la célula endotelial.

El segundo capítulo describe:

- la construcción de 1 clon codificante de la proteína CTB en fusión con LipL32;

- la expresión y purificación de la proteína recombinante;

- la producción de antisuero contra la proteína recombinante;

- el análisis de la reactividad de la proteína recombinante contra sueros de pacientes convalecientes;

- el estudio de la capacidad de la proteína recombinante para proteger a animales inmunizados con la misma frente a la infección con leptospiras patogénicas;

- el análisis de la respuesta inmune de los animales inmunizados. 


\section{Materiales y Métodos}

\subsection{Productos químicos y enzimas}

Los reactivos químicos utilizados así como los reactivos de biología molecular fueron de grado analítico. El agua utilizada fué destilada o bidestilada (según necesidad), deionizada y esterilizada por autoclave a $121^{\circ} \mathrm{C}$.

\subsection{Medios}

\subsubsection{LB (Luria-Bertani)}

En este medio se crecieron todas las cepas de E. Coli. Se preparo con Triptona $10 \mathrm{~g} / \mathrm{L}$, extracto de levaduras $5 \mathrm{~g} / \mathrm{L}, \mathrm{NaCl} 10 \mathrm{~g} / \mathrm{L}$. Para la preparación de placas, se añadió $15 \mathrm{~g} / \mathrm{L}$ de agar. Para la preparación del medio de las células BL21 SI, se procedió en forma idéntica pero sin el agregado de $\mathrm{NaCl}$. Para selección de colonias positivas de un plásmido determinado, se utilizó como medio LB con el agregado de ampicilina $(100 \mu \mathrm{g} / \mathrm{ml})$ ya que todos los plásmidos utilizados poseen resistencia a este antibiótico mediante la liberación de $\beta$-Lactamasas al medio.

\subsubsection{Medio Enriquecido EMJH para Leptospira}

Consta del medio EMJH base suplementado con albumina, polisorbato $80 \mathrm{y}$ factores de crecimiento adicionales para Leptospira. El medio base contiene cloruro de amonio como fuente de nitrógeno, tiamina como factor de crecimiento, la capacidad de buffer la proveen el fosfato disódico y el fosfato monobásico de potasio. Además contiene cloruro de sodio que aporta los iones esenciales.

\subsubsection{Medio RPMI}

Para el crecimiento y preparación de las células HUVEC, se utilizó medio RPMI 1640 (Sigma) suplementado con: 10\% suero fetal bobino, heparina $90 \mathrm{mg} / \mathrm{mL}$, suplemento de crecimiento de células endoteliales (ECGS), piruvato de sodio 2mM, L-glutamina $2 \mathrm{mM}$, penicilina $(100 \mathrm{U} / \mathrm{ml})$ y estreptomicina $(100 \mu / \mathrm{ml})$. 


\subsection{Cepas bacterianas utilizadas}

\subsubsection{Cepas de Leptospira}

La cepa de LIC, utilizada en el secuenciamiento previo, fue aislada de un paciente con leptospirosis severa en un brote epidémico en San Salvador de Bahía, Brasil, en 1996 y ha sido descripta previamente (L1-130) (57). Brevemente, se preparó un cultivo en medio $\mathrm{EMJH}$ a $28^{\circ} \mathrm{C}$, se alicuotó con glicerol al $10 \%$, y se mantuvo a $-70^{\circ} \mathrm{C}$ hasta su uso. La virulencia fué testeada en hamsters machos de 21-28 días de edad. Las cepas de $L$. interrogans serovares Canicola (Hond Utrechet IV), Copenhageni (M-20), Hardjo (Hardjoprajtino), Icterohaemorrhagiae (RGA), Pomona (Pomona) y Leptospira biflexa serovar Patoc (Patoc 1) fueron cultivados en la Facultad de Medicina Veterinaria, Universidad de San Pablo, Brasil.

\subsubsection{Cepas de Escherichia coli}

Las cepas E. coli utilizadas en el presente trabajo se describen genotípicamente en la Tabla 2.1.

\begin{tabular}{|c|c|c|}
\hline Cepa & Genotipo relevante & $\begin{array}{l}\text { Utilización } \\
\text { en este } \\
\text { trabajo }\end{array}$ \\
\hline DH5a & $\begin{array}{l}\text { F- } \quad \text { 80lacZ } \Delta \text { M15 } \Delta(\text { lacZYA-argF) } \quad \text { U169 } \\
\text { endA1 recA1 hsdR17 (rk-, mk+) supE44 thi-1 } \\
\text { gyrA96 relA1 phoA }\end{array}$ & $\begin{array}{l}\text { Amplificación } \\
\text { de vectores }\end{array}$ \\
\hline BL21 (DE3) & F- ompT hsdSB (rB-, mB-) gal dcm (DE3) & Expresión \\
\hline BL21 SI & $\begin{array}{l}\text { F- ompT hsdSB(rB-, mB-) gal dem endA1 } \\
\text { lon- proUp::T7 RNAP::malQ-lacZ (TetS) }\end{array}$ & Expresión \\
\hline $\begin{array}{l}\text { BL21 } \quad \text { (DE3) } \\
\text { Plys S }\end{array}$ & $\begin{array}{l}\text { F- ompT hsdSB (rB-, mB-) gal dem (DE3) } \\
\text { pLysS (CamR) }\end{array}$ & Expresión \\
\hline C43 (DE3) & F- ompT hsdSB (rB- mB-) gal dcm (DE3) & Expresión \\
\hline
\end{tabular}

\subsection{Plásmidos}

\subsection{1 pAE}

Es un vector para expresión y purificación de proteínas recombinantes, el cual posee un origen de replicación para E. coli. Fué construido en base a otros dos 
vectores, el pET3-His y el pRSET, dando como resultado un vector de reducido tamaño (2.822 nts), que adiciona un tag de 6 histidinas en el extremo amino terminal de la proteína, lo que permite una rápida purificación de la proteína de interés (Figura 2.1A). Debido a su tamaño este plásmido permite la inserción de grandes fragmentos de DNA, los cuales se insertan bajo un promotor fuerte del bacteriófago T7 generando un alto contenido de copias por célula $(-250)$ que resulta en una alta cantidad de proteína purificada ( $\sim 20 \mathrm{mg} / \mathrm{L}$ de cultivo).

El plásmido pAE posee un gen que codifica para una $\beta$-lactamasa que proporciona resistencia a ampicilina (Amp). La transformación de $E$. coli con plásmidos recombinantes conteniendo Amp permite su selección en medio LB suplementado con ese antibiótico. Posee sitios de primming de secuencias específicas y conocidas de T7 y de pRSET que pueden ser utilizados para comprobar la correcta inserción del gen de interés, así como para estudios de secuenciamiento.

\subsubsection{PAE-CTB}

Para la generación de este plásmido, se rediseño el gen de CTB de tal manera que sus codones sean reconocidos por E. coli, L. casei y S. Typhimurium. Se agregaron sitios de corte para varias enzimas y se eliminó cualquier posible estructura tipo hairpin a fin de mejorar la eficiencia del mismo (Figura 2.1B). Luego de la inserción en el vector pAE, se expresó comprobando el ensamblado de la proteína pentamérica, lo cual indica el correcto plegado de los monómeros de CTB y se verificó el reconocimiento de ésta por anticuerpos contra CT. El vector original fue gentilmente cedido por el Dr. P. L. Ho, del Laboratorio de Biotecnología Molecular, Instituto Butantan, SP, Brasil. 
Figura 2.1 Esquema de los vectores pAE (A) y pAE-CTB (B). 
Figura 2.2 Secuencia del gen CTB modificada. En gris se muestra el fragmento que se deleciona cuando se inserta el gen de LipL32.

\subsection{Selección in silico de LIC10365}

La localización celular de la proteína fue predicha por el programa PSORT, http://psort.nibb.ac.jp (81). La determinación del péptido señal, el sitio de clivado de la lipoproteína y los dominios transmembrana se basaron en los siguientes servidores públicos (9, 53, 100):

http://www.cbs.dtu.dk/services/SignalP, http://www.cbs.dtu.dk/services/LipoP/, http://www.cbs.dtu.dk/services/TMHMM 


\subsection{Aislamiento de DNA genómico bacteriano}

El DNA genómico de cada cepa fue aislado del pellet bacteriano con una solución de lisis a base de detergente y guanidina (DNAzol®, Invitrogen), lo cual permitió la precipitación selectiva del DNA a partir de un lisado celular. El procedimiento constó básicamente de 4 pasos: 1) homogenización de la muestra con DNAzol ${ }^{\circledR}$; 2) precipitación con etanol absoluto; 3) lavado con etanol 70\%; 4) solubilización del DNA en $\mathrm{H}_{2} \mathrm{O}$.

\subsection{Reacción en cadena de la polimerasa (PCR)}

La secuencia codificante predicha de LIC10365 fue amplificada por PCR a partir del DNA genómico de LIC. Para dicha amplificación se utilizaron primers $\begin{array}{lllll}\text { específicos } & \text { (F } & \text { ggatccagcggcgaaaacagtaacg) } & \text { y } & \text { (R }\end{array}$ ggtacctcactcgagtttacaagcgtttggag), diseñados específicamente con el fín de excluir la región del péptido señal.

En el caso de LipL32, se utilizó como molde el gen previamente clonado en el vector pDEST (35) y los primers específicos (F aattaaacgcgtggtgctttcggt) y $(R$ accaccaagcttattacttagtcg).

Las condiciones de annealing y de extensión fueron distintas para cada experimento ya que esto depende del tamaño del gen ( 1 min por $1 \mathrm{~Kb})$.

Se usaron tanto Taq (UNQ) como Pfx platinum (Invitrogen), siendo la elección de las enzimas dependiente de la finalidad de la PCR. Por ej.: para reacciones de verificación de inserto (screening) se utilizó Taq y para la amplificación de fragmentos para su posterior clonado se utilizó Pfx, por su alta fidelidad en el copiado, ya que a diferencia de la Taq posee actividad exonucleasa (proofreading) 3'-5'.

Para llevar a cabo la reacción se usaron tanto el buffer como la sal de magnesio provisto por el fabricante a la concentración indicada como óptima con excepción de la Pfx, la cual se ensayó primero en un gradiente de concentraciones de magnesio para analizar la más propicia.

Los fragmentos de PCR fueron purificados por gel utilizando un kit comercial y siguiendo las instrucciones del fabricante (Concert Rapid Gel Extraction System, Life Technologies) para ser clonados en el vector de expresión pAE de E. coli (91) en los sitios de restricción BamHI y KpnI en el caso de LIC10365 y Mlul y HindIII para LipL32. Las construcciones fueron verificadas por 
secuenciamiento del DNA en un secuenciador ABI Prism 3730 (Seq-Wright, Houston, TX) con primers de la secuencia de T7 y específicos del vector ( $F$ taatacgactcactataggg) y pAE (R cagcagccaactcagttcct).

\subsection{Minipreps}

La amplificación de plásmidos a baja escala (minipreps) fueron hechas por el procedimiento de lisis alcalina, siguiendo un protocolo estandard (95) y por la utilización del Kit PureLink ${ }^{\text {TM }}$ Quick Plasmid Miniprep (Invitrogen) siguiendo las intrucciones del fabricante, la elección del método dependió del grado de purificación deseado, siendo el kit la elección para la secuenciación.

\subsection{Digestión por enzimas de restricción}

Las digestiones con las enzimas Mlu I (Amersham), Hind III, Kpn I, y BamH I (promega), fueron realizadas en las condiciones óptimas para la enzima siguiendo las indicaciones del fabricante. En el caso de las digestiones dobles se utilizó un buffer en el cual ambas enzimas tuvieran el porcentaje más alto de actividad.

La concentración de los fragmentos de DNA, se estimó, en forma aproximada, por comparación con la intensidad de fluorescencia producida después de la electroforesis en gel en comparación con los fragmentos presentes en el patrón de PM de concentración conocida.

Las digestiones se incubaron a la temperatura óptima y se comprobaron por electroforesis en gel de agarosa, corriendo una pequeña alícuota antes de inactivar la enzima, La inactivación de las enzimas se llevó a cabo según indica el protocolo del fabricante.

\subsection{Electroforesis en gel de agarosa}

Las muestras de DNA fueron verificadas mediante electroforesis en gel de agarosa. Las concentraciones de los geles dependieron de la muestra a correr así como el marcador de PM utilizado. Las muestras fueron sembradas con Loading Buffer (azul de bromofenol 0,25\% y sacarosa 40\% p/v en agua).

La electroforesis fue realizada en Buffer TAE con 1\% de bromuro de etideo. El voltaje así como el tiempo de corrida dependió de la muestra, el gel y la 
finalidad de la corrida. La migración de las bandas se observó en un transiluminador de luz UV.

\subsection{Purificación de fragmentos de DNA}

Para llevar a cabo la purificación, las muestras fueron corridas en geles de concentración menores a $1 \%$ de agarosa o menos. Luego de que las bandas se separaran lo suficiente, se cortó la banda de interés del gel con un bisturí y se colocó en un eppendorff, tratando de exponer el menor tiempo posible a la luz UV para evitar dímeros de timina y por tanto mutaciones no deseadas. De ahí en más se procedió con la purificación según el protocolo del fabricante utilizando el kit PureLink ${ }^{\mathrm{TM}}$ Quick Plasmid Miniprep Kit (Invitrogen).

En algunos casos se uso fibra de vidrio para la purificación de bandas ya que en este procedimiento se pierde menos producto, el principio de este método es pasar la banda cortada por un filtro de fibra de vidrio confeccionado en forma casera, recuperando el DNA. El DNA se guardo a $-20{ }^{\circ} \mathrm{C}$ hasta su utilización, en una solución de $\mathrm{H}_{2} \mathrm{O}$-buffer TE (10 mM Tris-Cl, 1 mM EDTA) en una concentración 5:1.

\subsection{Reacción de ligación}

Una vez purificados los productos de las reacciones de digestión fueron corridos en un gel de agarosa para determinar la concentración de cada uno y poder calcular la relación necesaria para la ligación. Para estimar la cantidad de cada DNA que se debía agregar al tubo de ligación se tuvo en cuenta la relación molar entre los fragmentos a ser ligados, siguiendo la ecuación:

Masa Vector (ng) x Tamaño inserto $(\mathrm{pb}) /$ Tamaño vector $(\mathrm{pb}) \times \mathrm{I} / \mathrm{V}=$ Masa inserto (ng).

Se utilizó una relación 3:1 Inserto/Vector en el proceso de ligación.

Para realizar la ligación se procedió de la siguiente manera: se mezclaron el Buffer correspondiente a la enzima, ambos DNAs en las concentraciones adecuadas y el $\mathrm{H}_{2} \mathrm{O}$, se calentó por 5 minutos a $65^{\circ} \mathrm{C}$ y se colocó en hielo para romper cualquier interacción que pueda existir. Luego se agregó la enzima de ligación T4 ligasa (Promega) y se incubó entre 8 y $17^{\circ} \mathrm{C}$ por aproximadamente 20 hs. Se hicieron los siguientes controles: 
- Vector sin inserto y con ligasa: Control de digestión

- Vector sin inserto y sin ligasa: Control de digestión

- Inserto y ligasa: Control de contaminación.

De esta forma, los fragmentos amplificados por PCR, digeridos y purificados fueron clonados en los vectores correspondientes. Para el caso de LIC 10365 se uso el vector pAE (Figura 2.3) el cual fué digerido con el mismo par de enzimas que el fragmento amplificado del gen (Kpn I y BamH I) y para LipL32 se usó el mismo vector pero en este ya estaba insertado el gen modificado de CTB, la inserción fué dirigida hacia la porción terminal de este gen, logrando una fusión entre proteínas, en este caso tanto el vector como el gen amplificado fueron digeridos con Mlu I y Hind III (Figura 2.4).

Figura 2.3 Esquema del clonado de LIC10365. 
Figura 2.4 Esquema de la construcción de pAE-CTB-LipL32.

\subsection{Obtención de células competentes}

Se usó una técnica ya descripta (110) que básicamente consta de inocular 500 $\mathrm{ml}$ de medio LB sin $\mathrm{Na}$ con $1 \mathrm{ml}$ de cultivo saturado, proveniente del stock, incubado overnight a $37{ }^{\circ} \mathrm{C}$ y con agitación vigorosa. Cuando la $\mathrm{DO}_{600} \mathrm{~nm}$ del cultivo llegó a 0.8 las células fueron centrifugadas a $4000 \mathrm{rpm}$ durante 15 minutos a $4^{\circ} \mathrm{C}$ y lavadas 2 veces con $200 \mathrm{ml}$ de glicerol $10 \%$ a $4{ }^{\circ} \mathrm{C}$. Finalmente se resuspendieron suavemente en $0.5 \mathrm{ml}$ de glicerol $10 \%$ y se guardaron a $-80^{\circ} \mathrm{C}$ hasta su utilización.

\subsection{Transformación}

La transformación fué realizada mediante electroporación, donde se somete a la bacteria a campos eléctricos pulsantes que producen poros en la pared, lo que permite el ingreso del DNA.

Se mezclaron las células competentes recién descongeladas con el DNA a transformar, y se mantuvieron en frío durante aproximadamente 1 min. Luego se electroporaron en las condiciones ya descriptas para estas células (2.2 kV; $200 \Omega ; 25 \mu \mathrm{FD}$ ). Para esto se uso un equipo Gene Pulser ${ }^{\text {TM }}$ (Bio-Rad) y cubetas de $0,2 \mathrm{ml}$.

Una vez electroporadas, se les agregó medio LB, se incubaron a $37^{\circ} \mathrm{C}$ con una agitación de $180 \mathrm{rpm}$ durante $1 \mathrm{~h}$ para permitir la expresión del fenotipo de resistencia. Pasado ese tiempo se plaquearon en medio sólido de LB con 
antibiótico (Amp), y se incubaron a $37{ }^{\circ} \mathrm{C}$ aproximadamente $16-18$ hs. En cada caso se hicieron los siguientes controles: a) control negativo para ver si el sistema estaba contaminado, donde el DNA fue reemplazado con $\mathrm{H}_{2} \mathrm{O}$; b) control positivo donde se electroporó un plásmido cuantificado a $\mathrm{DO}_{286} \mathrm{~nm}$ para sacar la eficiencia de transformación, según la siguiente fórmula:

\section{Eficiencia de transformación=Colonias / $\mu \mathrm{g}$ DNA}

Para identificar los clones positivos que contienen el vector con el inserto, se procedió a picar con un palillo las colonias transformadas y crecida con medio selectivo y se resuspendieron en $\mathrm{H}_{2} \mathrm{O}$, se calentaron para romper las bacterias, se centrifugaron para obtener solo la parte soluble y eso se usó como molde de DNA para una PCR con primers que flanqueaban el inserto. Al mismo tiempo se realizó una estría en LB con Amp, para su posterior identificación.

\subsection{Cinética de expresión}

Para determinar la expresión de la proteína y su ubicación celular, ya sea en forma soluble o en cuerpos de inclusión, se tomaron muestras de cultivos inducidos cada 20 min. Los cuerpos de inclusión son agregados insolubles de proteínas no funcionales. Para esto se realizó un experimento para determinar primero el mejor proceso para romper las células y obtener la fase soluble de ellas sin romper los cuerpos de inclusión.

Los métodos que se ensayaron fueron los siguientes:

Sonicación: Se sonicaron 3 pulsos de 15 segundos a $38 \%$ de amplitud en un sonicador Branson sonifier 150.

Congelar y descongelar: Se congelaron y descongelaron las muestras 3 veces pasándolas de nitrógeno líquido a un baño de $37^{\circ} \mathrm{C}$.

Perlas de vidrio: Se agregó al pellet de células una cantidad igual de volumen de perlas de vidrio menores a $0.5 \mathrm{~mm}$. y se procedió a su agitación mediante vortex, se hicieron varios ciclos hasta ver una clarificación del medio, incubando las muestra en hielo entre cada ciclo para que la temperatura no aumentara y no se desnaturalizara la proteína. 
French Press: Se pasaron las bacterias resuspendidas en el buffer de lisis de 2 a 4 veces hasta ver la clarificación del medio $(\mathrm{NaCl} 500 \mathrm{mM}$, Tris- $\mathrm{HCl} 20 \mathrm{mM}$, y $0.1 \%$ Triton $\mathrm{X}-100, \mathrm{pH} 8.0$ ).

Luego de cada proceso de ruptura, se centrifugaron por 10 min y se separaron ambas fases, la fase soluble y los cuerpos de inclusión. Se verificó la expresión por electroforesis en geles de poliacrilamida.

\section{16 Expresión, purificación y renaturalización}

\section{16.1 Expresión}

Para la expresión de las proteínas se usaron células E. coli C43 (DE3) y BL21 (SI), las cuales fueron transformadas con pAE-LIC10365 o pAE-CTB-LipL32, respectivamente e incubadas durante $16 \mathrm{hs}$ en medio LB a $37^{\circ} \mathrm{C}(\mathrm{C} 43)$ y a 30 ${ }^{\circ} \mathrm{C}$ las BL21 (a esta temperatura se incrementa la solubilidad de la proteína y se reduce la formación de cuerpos de inclusión).

Cuando el cultivo llego a la saturación, fué diluido entre 30 y 50 veces para que en el momento de la inducción todas las bacterias estuvieran parejas en su estadio óptimo de crecimiento, que es la fase exponencial. Esta dilución también sirve para diluir las B-Lactamasas solubles secretadas al medio que pueden apantallar el crecimiento del fenotipo sin resistencia. El crecimiento fué monitoreado tomando cada 20-30 minutos la $\mathrm{DO}_{600} \mathrm{~nm}$ hasta que se alcanzó una $\mathrm{DO}_{600} \mathrm{~nm}$ de 06-08, donde fué inducida la expresión de la proteína recombinante mediante la incorporación de IPTG $1 \mathrm{mM}$ para las células transformadas de E. Coli C43 (DE3) y NaCl 300mm para las BL21 (SI).

Se tomaron muestras a distintos tiempos y se midió la $\mathrm{DO}_{600 \mathrm{~nm}}$ para constatar la correcta expresión que va acompañada de una fase semi estacionaria del cultivo, estas muestras fueron usadas para analizar la expresión de la proteína de interés por electroforesis en geles de poliacrilamida (cinética de expresión). Las muestras para el gel fueron centrifugadas por $2 \mathrm{~min}$ a $14.000 \mathrm{~g}$, el pellet fué resuspendido en SDS-LB (Tris-Cl 100mM (pH 6.8), DTT 200 mM, SDS 4\%, bromofenol blue $0.2 \%$ y glicerol $20 \%$ y hervidas por 10 min. Por último, se pasaron a través de una jeringa varias veces para romper el DNA y fueron centrifugadas nuevamente por $10 \mathrm{~min}$.

La inducción se mantuvo por 3-4 hs en agitación a las mismas temperaturas anteriormente mencionadas. Las células fueron cosechadas por centrifugación 
y el pellet fue resuspendido en $30 \mathrm{~mL}$ del buffer de lisis $(\mathrm{NaCl} 500 \mathrm{mM}$, Tris- $\mathrm{HCl}$ $20 \mathrm{mM}$, y $0.1 \%$ Triton X-100, pH 8.0). La lisis se hizo mediante una French Press (Aminco). La fracción insoluble fue lavada 3 veces con $30 \mathrm{~mL}$ de buffer (Tris- $\mathrm{HCl} 20 \mathrm{mM}, \mathrm{NaCl} 500$ mM, B-mercaptoetanol $1 \mathrm{mM}$, urea $1 \mathrm{M}$ y Triton X$1001 \%)$ y luego fue solubilizada en $50 \mathrm{~mL}$ de buffer conteniendo Tris- $\mathrm{HCl} 20$ $\mathrm{mM}, \mathrm{NaCl} 500 \mathrm{mM}$, b-mercaptoetanol $5 \mathrm{mM}$ y urea $8 \mathrm{M}$.

\subsubsection{Purificación y renaturalización}

Las proteínas fueron purificadas por cromatográfica de afinidad metálica utilizando una columna de flujo rápido conteniendo partículas cargadas con $\mathrm{Ni}^{2+}$ (GE Healthcare). Brevemente, la columna fué equilibrada con el buffer de unión y las proteínas fueron unidas a la columna por interacción de las histidinas con el $\mathrm{Ni}^{2+}$. Los contaminantes fueron descartados con lavados a bajas concentraciones de imidazol $(5,25,40$ and $60 \mathrm{mM}$ ) y las proteínas recombinantes fueron eluídas con imidazol 250-1 M. A continuación, las muestras fueron analizadas por SDS-PAGE 12-15\% y las fracciones de elusión conteniendo las proteínas recombinantes fueron dializadas en PBS con concentraciones decrecientes de imidazol hasta llegar a cero.

Cuando necesaria, la renaturalización de la proteína fue realizada por dilución en $2 \mathrm{~L}$ de buffer conteniendo (Tris- $\mathrm{HCl} 20$ mM, NaCl 500 mM e imidazol 5 mM).

\subsection{Antisueros contra rLIC10365 y CTB-LipL32}

Ratones hembras Balb/c de 6-8 semanas de edad fueron inmunizadas por vía intraperitoneal con aproximadamente 5-15 $\mu \mathrm{g}$ de cada proteína recombinante formulada con adyuvante completo de Freund. Pasados 21 días, los ratones recibieron nuevas inmunizaciones con las proteínas recombinantes formuladas con adyuvante incompleto de Freund. Luego de 2 semanas de la última inoculación los animales fueron sangrados y los sueros se titularon por ELISA. Como control se usó un grupo inoculado con una muestra procesada en forma idéntica excepto que las células fueron transformadas con un vector vacio.

\subsection{SDS-PAGE e inmunoblotting}

El procedimiento fue similar a uno ya descripto (85). Brevemente, las proteínas purificadas fueron separadas en geles de policrilamida al 12-15\% ( $p / v)$ con 
SDS (SDS-PAGE, del inglés sodium dodecyl sulfate-polyacrylamide gel electrophoresis). Luego de su separación, las proteínas fueron transferidas a membranas de nitrocelulosa o nylon. La transferencia se realizó en un equipo Owl para transferencias semisecas. Para un gel de $0.75 \mathrm{~mm}$ de 15 calles, aproximadamente de $8 \mathrm{~cm} \times 5 \mathrm{~cm}$, se transfirió a 15 volts durante $35-40 \mathrm{~min}$, previa incubación de la membrana y el gel en buffer de transferencia (Tris-base $48 \mathrm{mM}$, SDS $0.037 \%$, glicina $39 \mathrm{mM}$ y metanol 20\%) para las membranas de nylon Amersham Hybond ${ }^{\mathrm{TM}}$-P. Antes de bloquear la membrana, se verificó la correcta transferencia con rojo ponceau. Las membranas se bloquearon con TBS-T (TBS-tween 20 al 5\%: tris- $\mathrm{HCl} 10 \mathrm{mM} \mathrm{pH} \mathrm{7,5;} \mathrm{NaCl} 150 \mathrm{mM}$ ) suplementado con $5 \%$ de leche en polvo descremada durante 2 hs a fin de evitar el pegado inespecífico. Luego, se realizaron 4 lavados con TBS-T de 10 min cada uno. Se incubaron overnight en la heladera con el anticuerpo primario (suero de ratones inmunizados o de pacientes convalecientes gentilmente provistos por el Servicio de Zoonosis del Hospital Muñiz) con sus respectivos controles a diluciones acorde al título demostrado en los ELISAs previos. A continuación, se realizaron 4 lavados de 10 min cada uno con agitación suave. Los anticuerpos primarios fueron detectados por anticuerpos anti-IgG especie específicos unidos a HRP (horseradish peroxidase), los cuales fueron incubados a $37{ }^{\circ} \mathrm{C}$ por $2 \mathrm{hs}$. Nuevamente se realizaron sucesivos lavados y finalmente las membranas fueron reveladas con 3,3-diaminobenzidina (DAB) y con peróxido de hidrogeno $\left(\mathrm{H}_{2} \mathrm{O}_{2}\right)$ preparado en el momento.

\subsection{ELISA}

El análisis de la especificidad, del título de los sueros contra las proteínas recombinantes, así como de la unión de CTB-LipL32 a GM1 fue monitoreado por ELISA. Las placas de ELISA fueron sensibilizadas con las proteínas de interés (o con GM1) en una concentración aproximada de $0.5 \mu \mathrm{g}$ de proteína en buffer carbonato $\left(\mathrm{Na}_{2} \mathrm{CO}_{3} 0,05 \mathrm{M}, \mathrm{pH} 9,6\right)$ en un volumen final de $100 \mu /$ well por aproximadamente 14 horas a $4{ }^{\circ} \mathrm{C}$. Luego de lavados con PBS/Tween 0,05 $\%$, se bloqueó la unión inespecífica con $200 \mu$ l/well de una solución de buffer carbonato conteniendo $3 \%$ de BSA (o $5 \%$ de leche descremada) por 2 hs en estufa a $37^{\circ} \mathrm{C}$. A continuación se hicieron los lavados correspondientes con PBS/Tween $0,05 \%$ y se incubó con $100 \mu \mathrm{l} /$ well de diluciones seriadas del 
antisuero en buffer PBS conteniendo $1 \%$ de BSA y 0,05 \% de Tween 20 por 1 hora en estufa a $37^{\circ} \mathrm{C}$. Nuevamente se realizaron los respectivos lavados y se agregó $100 \mu \mathrm{l} /$ well de antisuero anti-IgG especie específico conjugado con peroxidasa (anti-ratón Dako o anti-humano Sigma) en una dilución de 1:2000, en buffer PBS conteniendo $1 \%$ de BSA y 0,05 \% de Tween 20 y se incubó por 1 hora en estufa a $37^{\circ} \mathrm{C}$. Se hicieron los lavados necesarios con PBS/Tween y se adicionó $100 \mu \mathrm{l} /$ well de la solución OPD (o-phenilenediamine) 0,4 mg/ml en buffer fosfato-citrato $0,05 \mathrm{M}$, pH 5.0 conteniendo $\mathrm{H}_{2} \mathrm{O}_{2}(10 \mu$ le solución $30 \%$ para un volumen de $20 \mathrm{ml}$ de substrato). La reacción fué interrumpida con 50 $\mu \mathrm{l} /$ well de la solución $\mathrm{H}_{2} \mathrm{SO}_{4} 2 \mathrm{M}$ y la absorbancia fué leída a $492 \mathrm{~nm}$ en lector de microplacas (Labsystems).

\subsection{Extracción de RNA y análisis de transcripción reversa (RT)-PCR}

Para realizar la transcripción reversa (RT)-PCR, se obtuvo primero el RNA total de los cultivos de leptospira empleando TRIzol Reagent (Invitrogen) siguiendo las recomendaciones del fabricante. Un microgramo de RNA de cada muestra fue tratado con $1 \mathrm{U}$ de DNAsa I (Invitrogen) por 15 min a TA y se inactivó con 1 $\mu \mathrm{L}$ de EDTA $25 \mathrm{mM}$ a $65 \mathrm{C}$ durante $10 \mathrm{~min}$. Para la transcripción reversa de las muestras de RNA tratadas con DNasa, se utilizó el sistema de síntesis de cDNA SuperScript III para RT-PCR (Invitrogen), siguiendo las recomendaciones del fabricante. Las reacciones de PCR y las condiciones del ciclado fueron similares a las mismas descriptas para el clonado de LIC10365. Todas las muestras fueron controladas con y sin el agregado de la enzima de retrotranscriptasa para descartar contaminaciones con DNA. Los productos amplificados de PCR fueron analizados por electroforesis en gel de agarosa 1 $\%$ y visualizados con tinción de bromuro de etidio.

\subsection{Inmunohistoquímica}

Con el fin de detectar la proteína codificadas por el gen LIC10365 en tejidos de riñón, se inocularon en forma intraperitoneal 3 hamsters de $180 \mathrm{gr}$ con $0.5 \mathrm{ml}$ de PBS ( $\mathrm{pH} \mathrm{7,2)} \mathrm{conteniendo} 10^{4}$ bacterias (LIC). A las 2 semanas PI, cuando los animales presentaban síntomas tales como letargia, fueron sacrificados. Los riñones fueron cosechados y procesados para histología de la manera habitual. Como controles se usaron animales inoculados con PBS. Luego de la 
rehidratación, los cortes de tejido montados sobre portaobjetos Pro-Bond Plus (TNT) fueron calentados durante 15 minutos en buffer citrato $10 \mathrm{mM}$ para lograr el desenmascaramiento antigénico. La actividad de la peroxidasa endógena fué previamente inhibida incubando los preparados durante 15 min con $3 \% \mathrm{H}_{2} \mathrm{O}_{2}$ y el bloqueo de sitios no específicos se realizó incubando 20 min con PBS y suero de cabra al $5 \%$ a TA.

Los tejidos fueron incubados con el suero policlonal de ratón descripto anteriormente en una dilución 1:100 por $1 \mathrm{~h}$ a TA o con suero de ratón antiLipL32 (35), como control positivo. Luego de sucesivos lavados con PBS, se incubó con el antisuero antiespecie marcado con biotina y luego de varios lavados con EnVision (DAKO) por 20 min a TA y se lavo nuevamente con PBS. Se reveló con DAB y $\mathrm{H}_{2} \mathrm{O}_{2}$ durante 2-10 min hasta alcanzar la intensidad apropiada y se frenó la reacción con agua destilada. Luego, las muestras fueron contracoloreadas con hematoxilina por $1 \mathrm{~min}$ y lavadas con agua corriente primero y con agua destilada después. Para deshidratar el preparado, se utilizaron concentraciones crecientes de etanol y por ultimo xileno (cada paso duro $5 \mathrm{~min}$ ). Finalmente, los preparados fueron montados con un cubreobjetos y observados en un fotomicroscopio Nikon E200.

\subsection{Ensayo de lisado de Limulus amebocyto (LAL test)}

Para detectar y cuantificar las endotoxinas lipopolisacáridas (LPS) contaminantes, se utilizó el ensayo de LAL en las muestras proteicas usando el kit QCL-1000 (Bio-Whittaker, Maryland), siguiendo las instrucciones del fabricante.

\subsection{Cultivo de células endoteliales}

Células endoteliales humanas (HUVECs) fueron obtenidas de cordón umbilical utilizando digestión con colagenasa (Gibco) de acuerdo a un método ya descripto (52). Las células fueron crecidas a confluencia en frascos de $25 \mathrm{~cm} 2$ revestidos con $1 \%$ de gelatina (Sigma). El medio de crecimiento consistió en RPMI 1640 suplementado con $10 \%$ de suero fetal bovino (SFB, Gibco), heparina (100 $\mu \mathrm{g} / \mathrm{ml})(\mathrm{Gibco})$, suplemento de factores de crecimiento de células endoteliales (50 $\mu \mathrm{g} / \mathrm{ml}$, Sigma), piruvato de sodio (2 mM), L-glutamina (2 mM), penicilina (100 U/ml, Sigma) y estreptomicina $\left(100 \mu \mathrm{g} / \mathrm{ml}\right.$, Sigma) a $37^{\circ} \mathrm{C}$ en 
atmosfera húmeda de $5 \% \mathrm{CO}_{2}$. Cuando los cultivos alcanzaron la confluencia se realizaron repiques a frascos o a placas de 6 o 24 wells, por tratamiento con solución de tripsina-EDTA (0,05\% y 0,1 mM, respectivamente), y se lavaron con PBS (sin calcio ni magnesio) suplementado con $10 \%$ SFB y fueron usadas entre el primer y tercer pasaje. Algunos experimentos fueron realizados en presencia de polimixina $B(7 \mu \mathrm{g} / \mathrm{ml})$ para eliminar posibles respuestas inducidas por la presencia de lipopolisacáridos bacterianos contaminantes. La proliferación de las células HUVECs fué monitoreada mediante el conteo de células en microscopio invertido de contraste de fase mantenidas en el medio descripto arriba en presencia de las proteínas recombinantes luego de 72 hs. Su identificación se basó en la morfología y su unión a anticuerpos anti-factor de von Willebrand (vWF) (Immunotech, Francia).

\subsection{Expresión de las moléculas de adhesión celular (CAMs) E-selectina e}

\section{ICAM-1}

Luego del tratamiento con LIC10365 a las concentraciones indicadas durante 1 h en medio RPMI-1640, la proteína fue removida por lavados sucesivos y las células HUVECs fueron incubadas en RPMI-1640 con 10 \% SFB. La expresión de ICAM-1 fué estudiada a las 12 hs. Para ello, las HUVECs fueron despegadas con la solución de tripsina-EDTA ya mencionada, centrifugadas, resuspendidas en PBS/SFB conteniendo concentraciones saturantes de anticuerpos monoclonales (mAbs) anti ICAM-1 (Pharmigen) conjugados con FITC (isotiocianato de fluoresceína). Para estudiar la expresión de E-selectina, las células fueron cosechadas luego de 4 hs e incubadas con el mAb anti CD62E (clon 1.2B6 Immunotech) y como anticuerpo secundario se uso $F(a b$ ')2 anti-ratón IgG (Immunotech) conjugado con FITC. Como control de unión no específica, los mAbs conjugados con FITC fueron reemplazados con mAbs del mismo isotipo irrelevantes a concentraciones equivalentes. Luego del marcado, las células fueron lavadas, fijadas con $1 \%$ de paraformaldehído y analizadas por citometría de flujo en un FACScan citofluorómetro (Becton Dickinson, CA).

Se establecieron parámetros apropiados de tamaño y complejidad y se analizaron 10.000 células por experimento. La unión inespecífica se estableció utilizando controles de isotipo. El porcentaje de células positivas fué 
determinado utilizando umbrales de positividad dados por los controles de isotipos.

\subsection{Desafío}

Con el fin de verificar la capacidad protectora de CTB-LipL32 in vivo se utilizaron hamsters (Mesocricetus auratus) machos adolescentes de 80-120 gr (3-4 semanas de vida), los cuales fueron inmunizados por vía intraperitoneal. Los grupos se organizaron de la siguiente manera: A) hamsters inmunizados con CTB-LipL32 (25 $\mu \mathrm{g} /$ animal); B) hamsters inmunizados con PBS; C) hamsters inmunizados con CTB (8 $\mu \mathrm{g} /$ animal); y D) hamsters inmunizados con LipL32 (17 $\mu \mathrm{g} /$ animal) en un volumen final de $0.5 \mathrm{~mL}$. En cada animal se realizaron 3 inmunizaciones con intervalos de 15 días cada una. Pasados los 15 días de la última inmunización, todos los animales fueron inoculados con 0.5 $\mathrm{ml}$ de PBS conteniendo aproximadamente $10^{4}$ células de LIC (L1-130) registrándose la mortalidad diariamente y sacrificándose a los sobrevivientes a los 28-30 días PI. El experimento se repitió 3 veces en 2 laboratorios diferentes utilizando 3-5 animales por grupo.

\subsubsection{Mortalidad}

La mortalidad fue monitoreada diariamente durante todo el período de observación (30 días) incluyendo síntomas de enfermedad terminal.

\subsubsection{Histopatología}

A los 14 y 30 días PI, grupos de 3 animales fueron sacrificados y diversos tejidos, incluyendo riñón, bazo y sangre fueron cosechados para su análisis histopatológico.

\subsubsection{Carga bacteriana}

La presencia de LIC a nivel del tejido renal fue establecida por tinción inmunohistoquímica utilizando antisueros específicos. Un análisis comparativo se realizó a continuación por observadores que desconocían la identidad de cada preparado. 


\subsection{Respuesta inmune humoral}

La presencia de anticuerpos específicos fué monitoreada por ELISA como se ha descripto (75).

\subsection{Análisis estadístico}

Todos los resultados fueron expresados como media \pm DS. Análisis de una-vía de varianza (ANOVA) seguido del procedimiento de múltiple comparación de Newman-Keuls. Los valores < 0.05 fueron considerados estadísticamente significativos. 


\section{Resultados}

\subsection{LIC10365}

\subsubsection{Análisis bioinformático de la secuencia de LIC10365}

El gen codificante de LIC10365 fué identificado en el cromosoma I luego del análisis de los probables ORFs presentes en el genoma de L. interrogans serovar Copenhageni $(83,84)$. El gen consiste en 1080 nucleótidos, que codifican una proteína de 359 aminoácidos. La búsqueda de motivos estructurales por los servers Lipo-P (53), TMHMM (100) y PSORT (81) predijo que LIC10365 es una lipoproteína externa de membrana.

Según Lipo-P, posee una señal de clivado tipo II en la posición 16-17 y dos señales de clivado tipo I en las posiciones 22-23 y 27-28, teniendo el mejor score el sitio de la posición 16-17 (53). El análisis por BLAST mostró que LIC10365 es parte de una familia de genes parálogos que incluye LIC11207 (50\% identidad, $65 \%$ similitud), LIC10821 (48\% identidad, $64 \%$ similitud), LIC10774 (38 \% identidad, $58 \%$ similitud) y LIC11030 (35 \% identidad, $48 \%$ similitud) (4, 97). Según el server PFAM (31), esta familia de proteínas tiene en común un dominio de función desconocida (DUF 1565). El punto isoeléctrico (pl) teórico es de 5.62 y la masa molecular (M) del polipéptido maduro y clivado es de 36400.41 Da.

Secuencias similares a LIC10365 fueron identificadas en L. interrogans serovar Lai (92) y en L. borgpetersenii serovar Hardjo-bovis strain JB197 (13).

\subsubsection{Expresión proteica, purificación y western blot}

La proteína recombinante rLIC10365 fué expresada en E. coli C43 (DE3). Esta cepa, inicialmente fue descripta por Microlux \& Walker (74) y se ha reportado que puede crecer hasta alcanzar altas densidades celulares y expresar proteínas globulares y de membrana sin efectos tóxicos para $E$. coli.

La proteína recombinante, estimada en $37.7 \mathrm{kDa}$, fue expresada en los cultivos inducidos (Figura 3.1A), el sistema tiene un nivel de expresión basal sin inducción.

La proteína LIC10365 fue expresada en forma insoluble en cuerpos de inclusión y debió ser solubilizada y renaturalizada antes de purificarla por la columna de sefarosa cargada con $\mathrm{Ni}^{2+}$. La proteína fue recuperada con imidazol 1M como la mayor banda proteica (Figura 3.1B). 
La reactividad de la proteína recombinante con el suero de ratón anti rLIC10365 mostró una banda correspondiente a rLIC10365 (Figura 3.1C y D) en la forma purificada y en el lisado proteico de las bacterias inducidas. Las bandas de menor peso molecular que aparecen en la Figura 3.1D son probablemente productos de degradación.

Figura 3.1. Expresión, purificación y western blot de rLIC10365 (rP). A: Expresión proteica de E. coli C43 (DE3) transformadas con pAE-LIC1065 en un SDS-PAGE 12\%. B: Elución con imidazol 1M de la proteína rLIC10365 purificada por la columna de sefarosa cargada con $\mathrm{Ni}^{2+}$. C: Proteínas transferidas a la membrana de western y teñidas con Ponceau S. D: Western blot con suero de ratón (1:1000) anti rLIC10365. Proteínas totales del extracto bacteriano: NI, no inducido; I, inducido. rP, proteína recombinante purificada; M, marcador de peso molecular de proteínas.

\subsubsection{Conservación de genes y proteínas entre cepas de Leptospira}

La conservación del gen de LIC10365 en cinco cepas patogénicas y en una saprófita no patogénica de Leptospira fué examinada por PCR con el mismo par de primers usados para la amplificación del gen. La banda correspondiente al gen de LIC10365 de 1038 nts fue amplificada por PCR en tres cepas patogénicas pertenecientes a la especie de L. interrogans (serovares Copenhageni, Hardjo e Icterohaemorraghie). No se detectó amplificación en las 
cepas pertenecientes a los serovares Canicola, Pomona y en la cepa no patogénica Patoc 1 (L. biflexa serovar Patoc) (Figura 3.2A).

La expresión de LIC10365 en cultivos in vitro de leptospiras se evaluó mediante amplificación por RT-PCR partiendo del RNA total. Los resultados obtenidos revelaron la presencia de transcripto de LIC10365 en las tres cepas mencionadas anteriormente (Figura 3.2B).

La contaminación por DNA fué descartada ya que no se observó amplificación en ausencia de la enzima transcriptasa reversa (Figura 3.2C).

La integridad de las muestras se verificó amplificando un fragmento de cDNA del 16S ribosomal de 1042 nts (no se muestra en la figura).

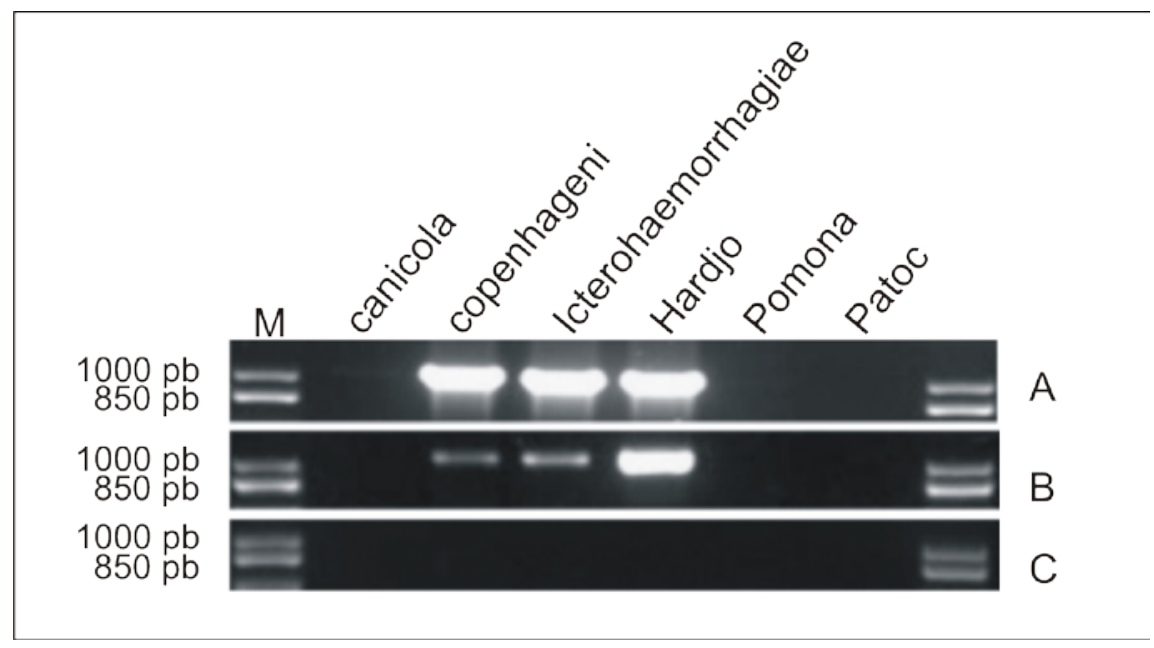

Figura 3.2. Conservación de genes y proteínas entre cepas de Leptospira. A: DNA genómico de Leptospira biflexa Patoc y de cinco serovares de especies patogénicas de Leptospira interrogans fueron analizados por PCR con primers específicos para LIC10365. El tamaño de amplificación esperado para el gen de LIC10365 es de 1038 nts. B: RT-PCR análisis de LIC10365 usando los mismos pares de primers mencionados anteriormente. C: Control de contaminación por DNA sin transcriptasa reversa. $M$, marcador de peso molecular.

\subsubsection{Evaluación inmunohistoquímica con suero anti-rLIC10365}

Los cortes histológicos realizados de riñones de cobayos obtenidos 14 días PI presentaron arquitectura cortical y medular bien conservada. Algunos pocos glomérulos se observaron contraídos, mientras que algunos túbulos contenían 
material proteico mezclado con eritrocitos. Un infiltrado celular mixto agudo se observó ocasionalmente en proximidad a grandes vasos.

La tinción positiva con el antisuero rLIC10365 localizó el antígeno de Leptospira en el lumen de los túbulos renales (Figura 3.3B). Por el contrario, se observó escasa cantidad de antígeno de LIC10365 infiltrado en los intersticios celulares del tejido inflamado.

Comparado con LipL32, un antígeno inmunodominante expresado en la infección experimental por leptospiras $(40,82)$ y usado como control positivo en este experimento, la tinción de la proteína LIC10365 fue menos intensa (Figura 3.3C). En el control negativo, el antisuero de rLIC10365 no mostro reactividad a tejidos de riñón de hamsters no infectados (Figura 3.3A).
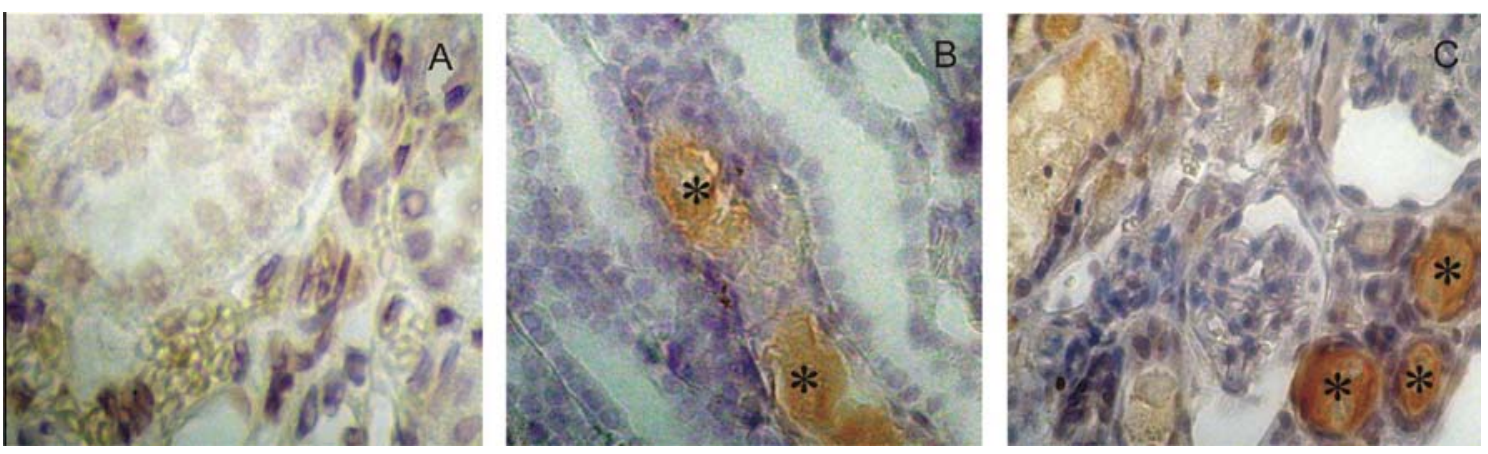

Figura 3.3. Inmunohistoquímica en tejido renal. Los tejidos fueron cosechados 14 días PI con L. interrogans virulentas. El antígeno (*) fué detectado en las leptospiras dentro del lumen de los túbulos renales tanto con suero antirLIC10365 (B), como antirLipL32 (C). Como control negativo se usaron animales no infectados con suero antirLIC10365 (A). En todos los casos, se utilizó como contraste una tinción con hematoxilina. A: x250; B y C: x400.

\subsubsection{Expresión de E-selectina e ICAM-1 en células endoteliales}

Para determinar si las células endoteliales son activadas por la exposición a rLIC10365, cultivos de HUVECs fueron tratados a las concentraciones indicadas de rLIC10365 y se evaluaron los niveles de la E-selectina y de ICAM1 de superficie por FACS (del inglés, fluorescence-activated cell sorter analisis). Previamente, se había demostrado que estas moléculas son activadas por proteínas de las espiroquetas patogénicas Borrelia spp (103-105) y Treponema 
spp (64). Los resultados muestran un incremento en la expresión basal de las dos CAMs después del tratamiento con rLIC10365 en forma dosis dependiente (Figura 3.4 A y B). Con el fín de excluir la incidencia del eventual LPS contaminante en el proceso de activación, se determinó el contenido de LPS de la muestra en $1.2 \times 10-2 \mu \mathrm{g} \mathrm{mL-1}$ por el ensayo LAL. La inducción de ICAM-1 en HUVECs por LPS se evaluó en presencia y en ausencia de $7 \mu \mathrm{g} \mathrm{mL-1}$ de polimixina B (Figura 3.4 C). Como control, se incluyó otra proteína recombinante, la rLIC10793 que contiene una concentración similar de LPS a la que tiene rLIC10365 y no se observó aumento en la expresión de ICAM-1. Este experimento sugirió fuertemente que la concentración de polimixina B utilizada fue suficiente para inactivar los lipopolisacáridos contaminantes que contenía la muestra, descartando la interferencia de LPS en la inducción de CAM por rLIC10365.

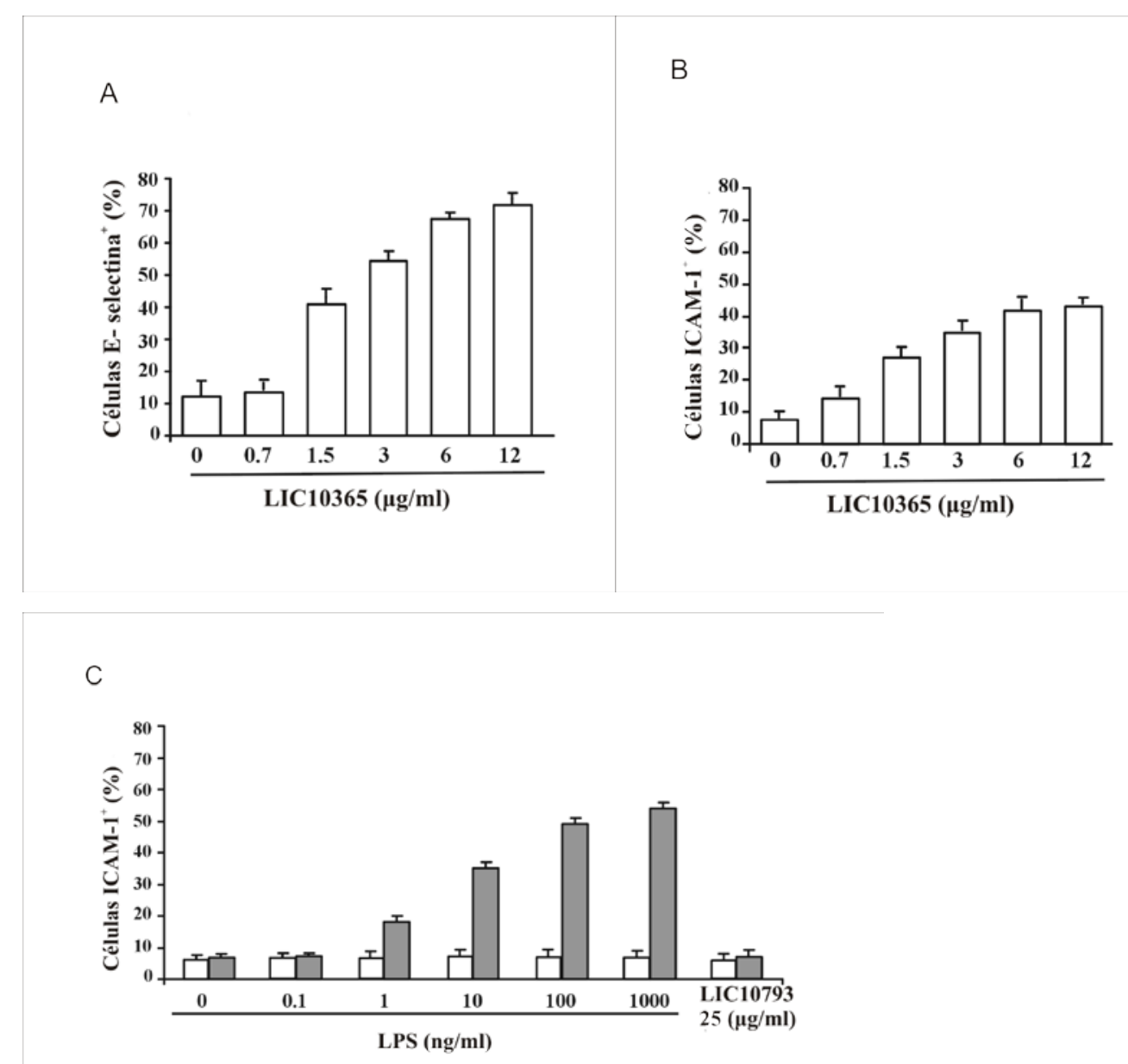

Figura 3.4 La proteína rLIC10365 induce en HUVECs la expresión de ICAM-1 y de E-selectinas de superficie. Monocapas confluentes de HUVECs fueron estimuladas por $1 \mathrm{~h}$ con rLIC10365 a las concentraciones indicadas. El 
medio fué removido y las células fueron crecidas en RPMI-1640 suplementado con 10\% SFB. A: La expresión de E-selectina fué evaluada 4 hs posestimulación, B: la expresión de ICAM-1 fue evaluada 12 hs posestimulación. Los datos representan la media \pm error estándar de cuatro experimentos independientes.

\subsubsection{Construcción del vector CTB-LIPL32}

El gen de LipL 32 fue amplificado por PCR del vector PDEST con primers que contenían los sitios de restricción para Mlu I y Hind III, con el fin de insertarlo dentro del gen de CTB, en su porción amino terminal, fusionando así ambas proteínas. El tamaño de amplificación esperado del gen LipL32 fué de 730 nts y con respecto al vector pAE-CTB linearizado se esperaba un tamaño de 3100 nts (Figura 3.5 A).

Luego se procedió a la digestión con las enzimas Mlu I y Hind III, tanto del vector PAE-CTB como de los productos de PCR y se comprobó la linearización del vector por electroforesis en geles de agarosa. Cabe aclarar que la diferencia entre los productos de PCR y los digeridos fué de $10 \mathrm{nts}$, por lo que no se ve la diferencia claramente en el gel (Figura $3.5 \mathrm{~B}$ ). Los fragmentos digeridos se incubaron con enzima T4 para su empalme, el producto fue electroporado y la búsqueda de clones positivos fue realizada por PCR (colonyPCR), logrando identificar dos clones positivos (Figura 3.5 C), los cuales fueron amplificados a baja escala y purificados.

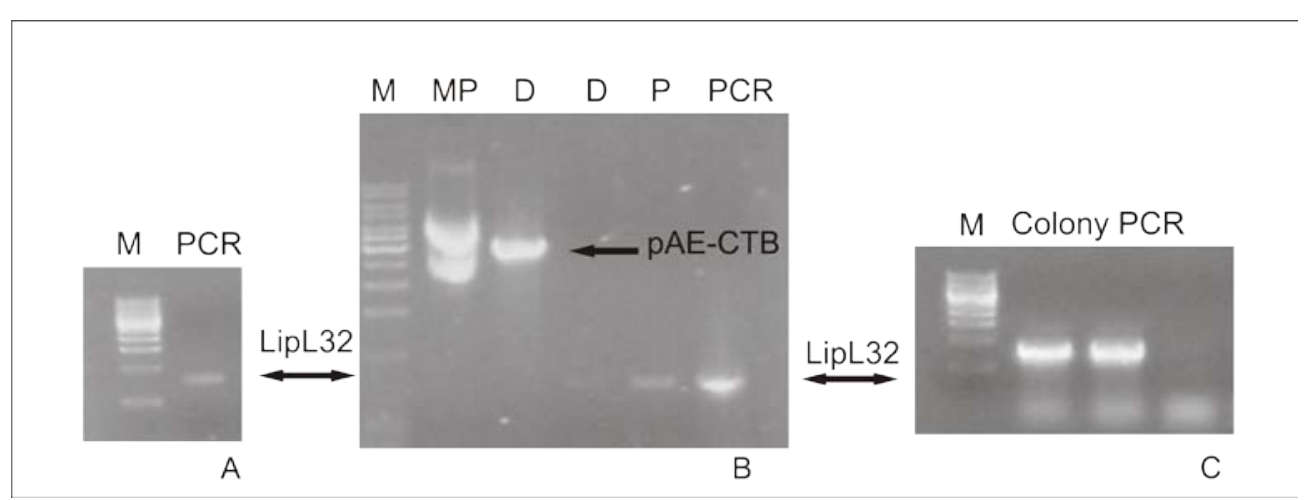

Figura 3.5 Clonación de pAE CTB-LipL 32. A: PCR de LipL 32 con los primers mencionados anteriormente, el tamaño de amplificación esperado es de 730 pb. B: Digestión de pAE CTB y de LipL 32 con Mlu I y Hind III. C: 
Colony PCR con primers que amplifican LipL 32. M, marcador de peso molecular. MP, miniprep. D, digestión.

\subsubsection{Expresión proteica, purificación y western blot de CTB-LipL32}

La proteína recombinante LipL32 fué expresada en E. coli (DE3) y (SI). Ambas cepas contienen el gen de la RNA polimerasa del fago T7 bajo un promotor inducible con IPTG en el caso de las DE3 y con $\mathrm{NaCl}$ en el caso de las SI. Esto por un lado minimiza el efecto tóxico que puede darse por la sobreexpresión de proteínas recombinantes y por otro es altamente específico, ya que expresa solo proteínas que estén bajo el promotor de T7. La diferencia de expresión entre ambas cepas dio como resultado una mayor proporción de proteína soluble en las SI en comparación con las DE3. Además se comprobó que entre 3 y 4 hs de inducción se produjo en mayor cantidad la proteína de interés en comparación con el resto de proteínas celulares, lo que en el caso de la purificación en forma soluble fué de gran utilidad.

La proteína recombinante, que contiene el tag de His y CTB fusionada a LipL32 tiene un peso de $45 \mathrm{kDa}$, en los cultivos inducidos se pudo ver un nivel de expresión basal sin inducción, producto de un escape del sistema como ocurrió con LIC10365 (Figura 3.6 A y B).

Para la ruptura celular y la posterior separación de fracciones solubles e insolubles el método que mejor funcionó fué utilizando la french press, con el cual se pudo mantener una mayor cantidad de proteína en forma soluble en su forma nativa.

La proteína LipL32 fue expresada tanto en forma soluble como insoluble en cuerpos de inclusión y esta última, al igual que LIC10365, debió ser solubilizada y renaturalizada antes de ser purificada por la columna de sefarosa cargada con $\mathrm{Ni}^{2+}$. La proteína fue efluida con imidazol 250mM. (Figura 3.6 C). La reactividad de la proteína recombinante con el suero de ratón anti-LipL32 mostró una banda del tamaño esperado (Figura 3.6 D) en la forma purificada. 


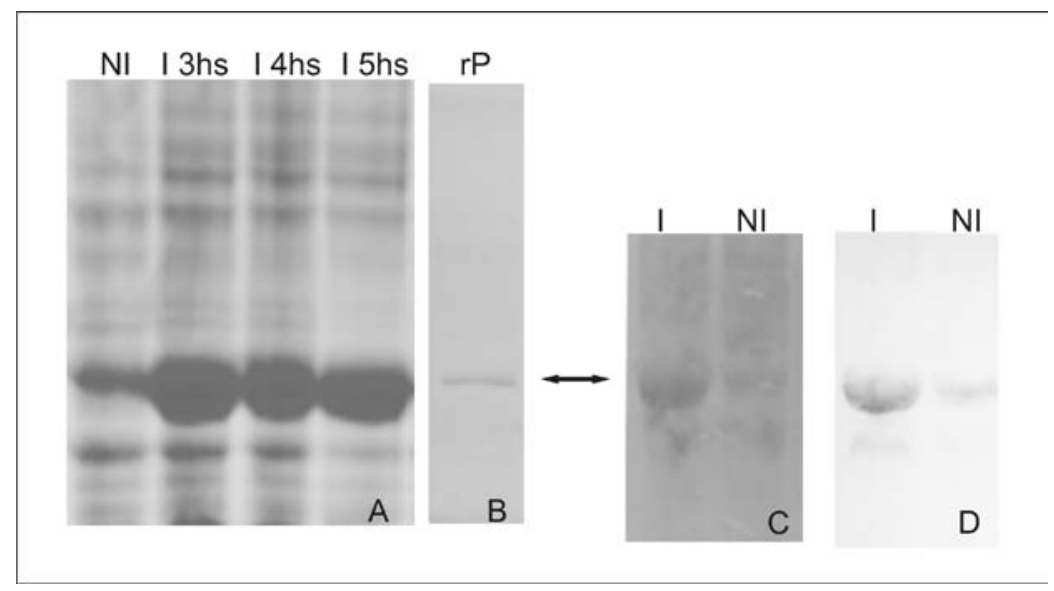

Figura 3.6 Expresión, purificación y western blot de CTB-LipL32 (rP). A: Expresión proteica de E. coli BL21 (SI) transformadas con PAE- CTB-LipL32 en un SDS-PAGE 12\%. B: Elución con imidazol 250mM de la proteína CTB-LipL32 purificada por la columna de sefarosa cargada con $\mathrm{Ni}^{2+}$. C: Gel hermano del transferido a la membrana. D: Western blot con suero de ratón (1:1000) anti LipL32. Proteínas totales del extracto bacteriano: NI, no inducido; I, inducido, rP, proteína recombinante purificada.

\subsubsection{Secuenciamiento de la construcción}

El correcto ensamblado y la secuencia específica de la fusión entre CTB y LipL32 fueron verificados por secuenciamiento de 3 clones representativos lo que nos dio la seguridad de que el marco de lectura de LipL32 estaba en su forma adecuada (Figura 3.7).

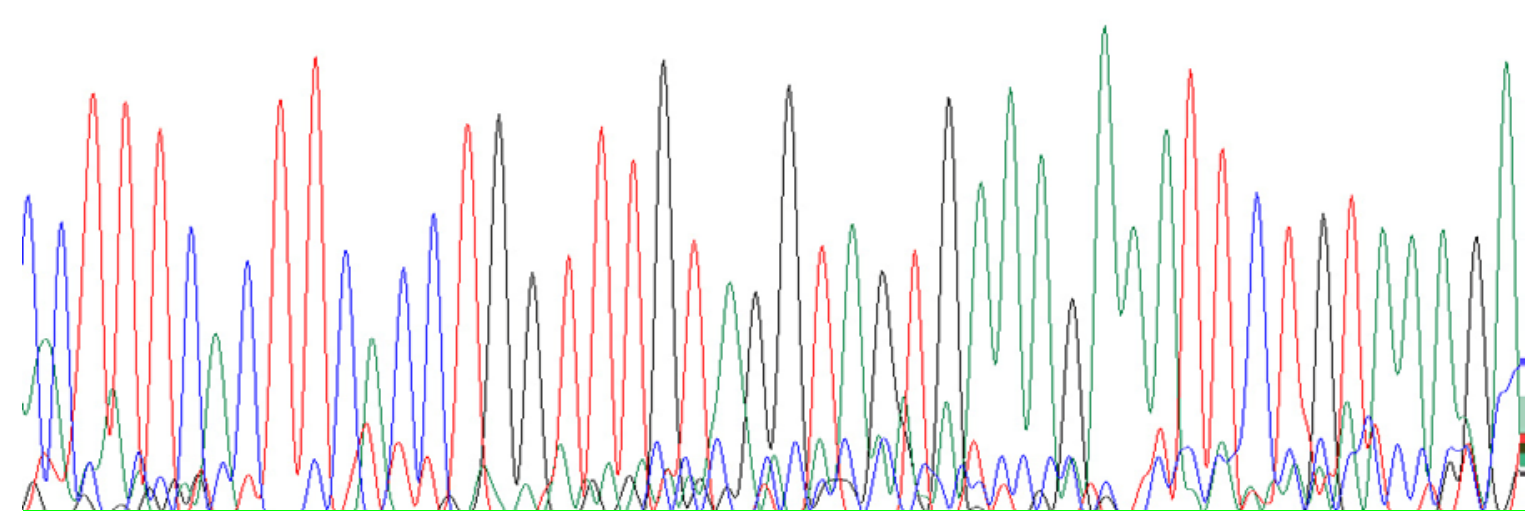

Figura 3.7 Imagen representativa del cromatograma realizado para corroborar el correcto clonado de las proteínas y su marco de lectura. 
3.2.4 Demostración de la estructura pentamérica de la proteína recombinante CTB-LipL32

Para corroborar el correcto plegado de CTB-LipL32 y su conformación pentamérica se realizó una electroforesis con una muestra en su estado nativo, para corroborar la formación del pentámero, y otra muestra a la cual se la desnaturalizó previamente con B-Mercapto y calor, para fines comparativos (Figura $3.8 \mathrm{~A}$ ). Cabe destacar que la forma nativa no migra en el gel en base a su masa solamente. Además, se realizó un ELISA con GM1 como substrato, ya que CTB se une a GM1 únicamente en su forma pentamérica. Para este ensayo, como control positivo se utilizó CTB comercial (Sigma) y como control negativo, LipL32 para descartar cualquier posible interacción con GM1 (Figura $3.8 \mathrm{~B})$.

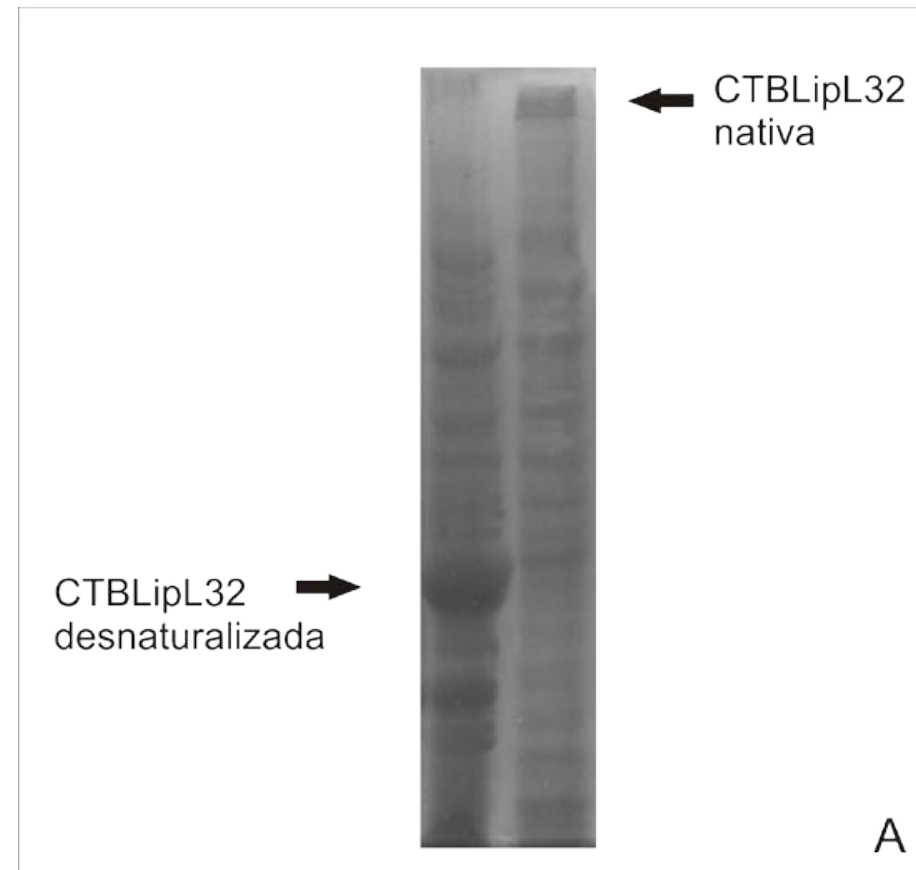


Figura 3.8 A: gel en condiciones nativas y desnaturalizantes. B: ELISA con GM1 como substrato incubado con CTB, CTB-LipL32 y LipL32 y sus respectivos antisueros.

\subsubsection{Reconocimiento de la proteína por suero de ratón inmunizado}

El pool de sueros de ratones inmunizados con CTB-LipL32 se tituló mediante ELISA. Se utilizaron antiCTB y antisuero anti la proteína $N$ del virus Junín en pocillo recubiertos con esta proteína como controles positivos y BSA con anti CTB como control negativo para validar el ensayo. Los resultados se muestran en la Figura 3.9. 


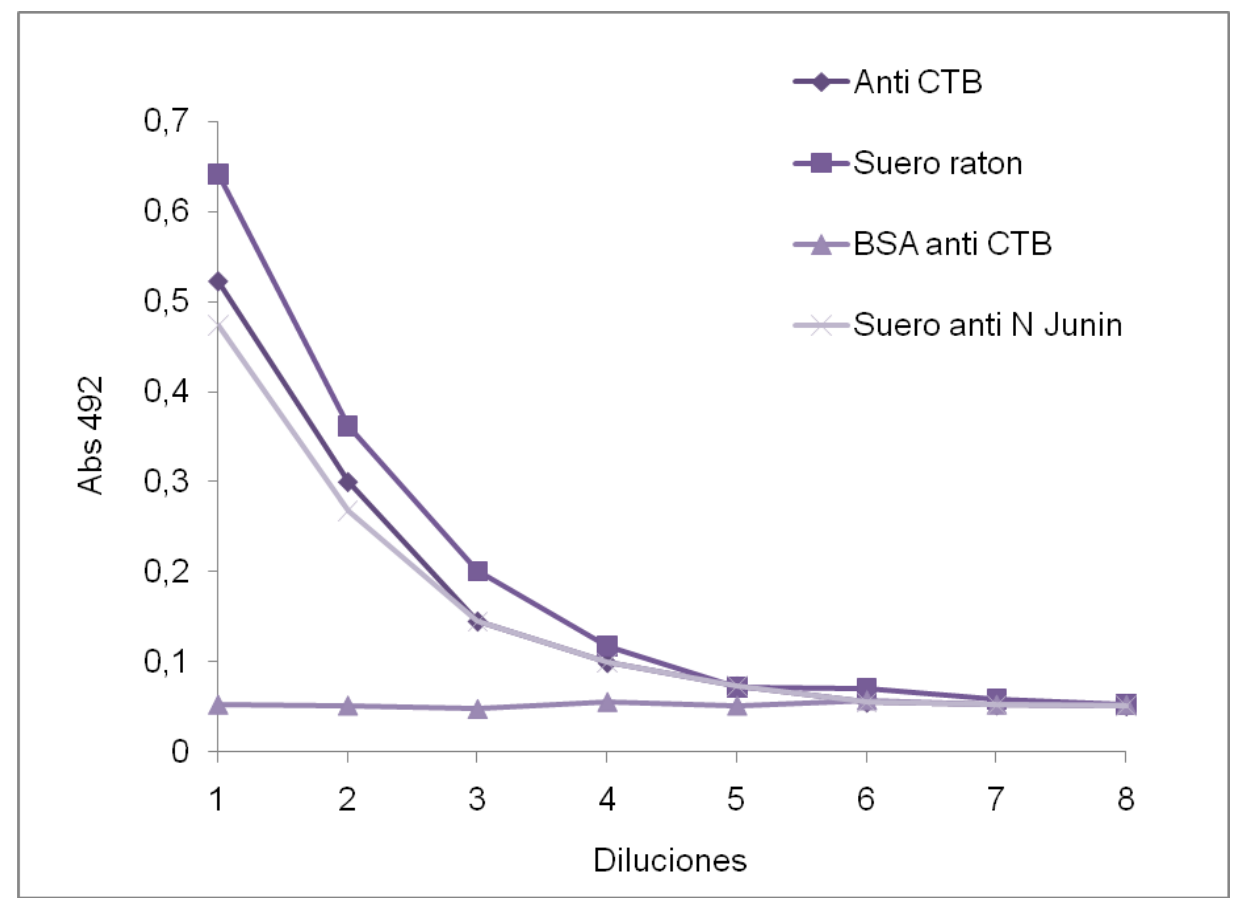

Figura 3.9 Reconocimiento de CTB-LipL32 por sueros murinos

\subsubsection{Reconocimiento de la proteína recombinante CTB-LipL32 por sueros de pacientes convalecientes}

La proteína purificada CTB-LipL32 demostró ser inmunogénica luego de su inoculación en ratones (Figura 3.9). Para tener un mayor conocimiento acerca del reconocimiento de la proteína por anticuerpos específicos, la misma fué utilizada en ensayos de ELISA con diversos sueros de pacientes convalecientes de leptospirosis y con sueros de pacientes sanos para leptospirosis y dos controles extras, uno negativo en el cual se usó un antisuero para la proteína $\mathrm{N}$ del virus Junín y uno positivo en el cual se utilizó anti LipL32 Los resultados indicaron que la proteína CTB-LipL32 fue reconocida por los sueros de los pacientes convalecientes y no por los sueros de los pacientes sanos ( $p=0.001)$ (Figura 3.10A-C). 


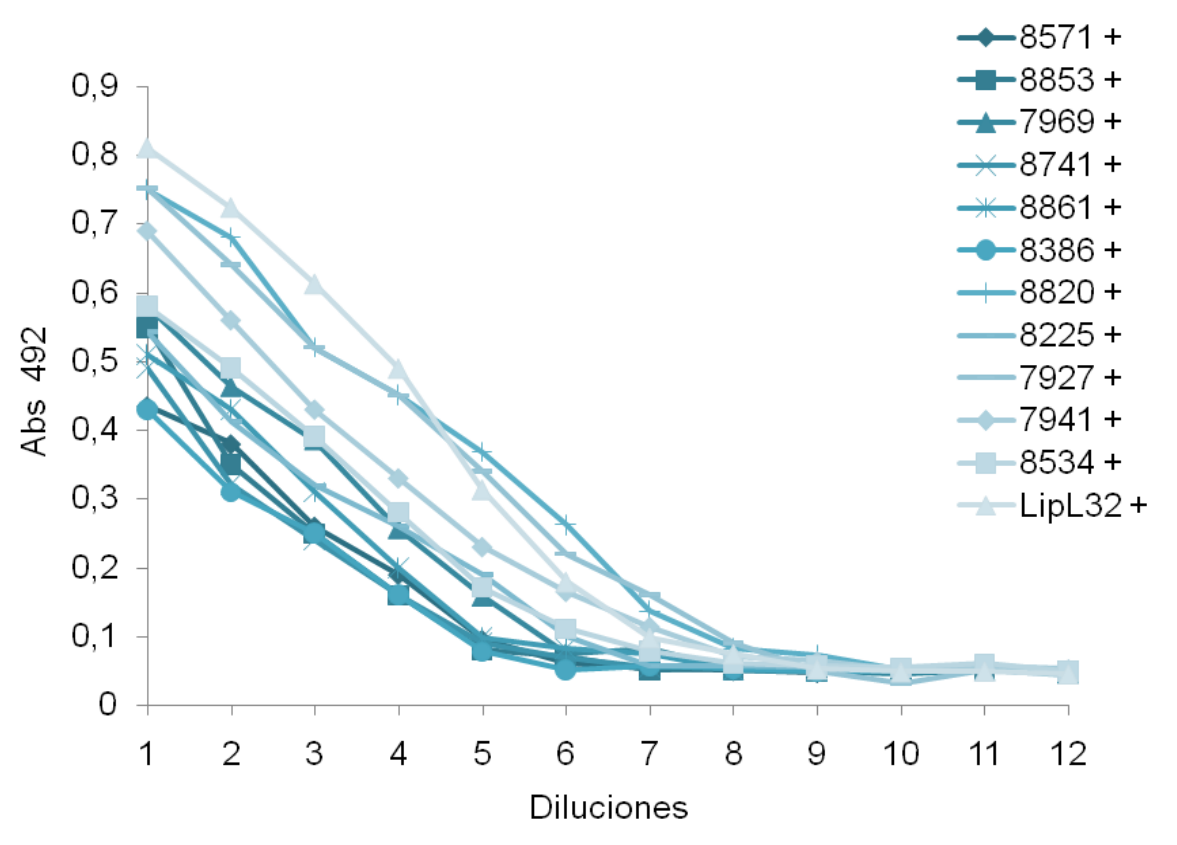

Figura 3.10A. Reconocimiento de sueros de pacientes convalecientes contra CTB-LipL32.

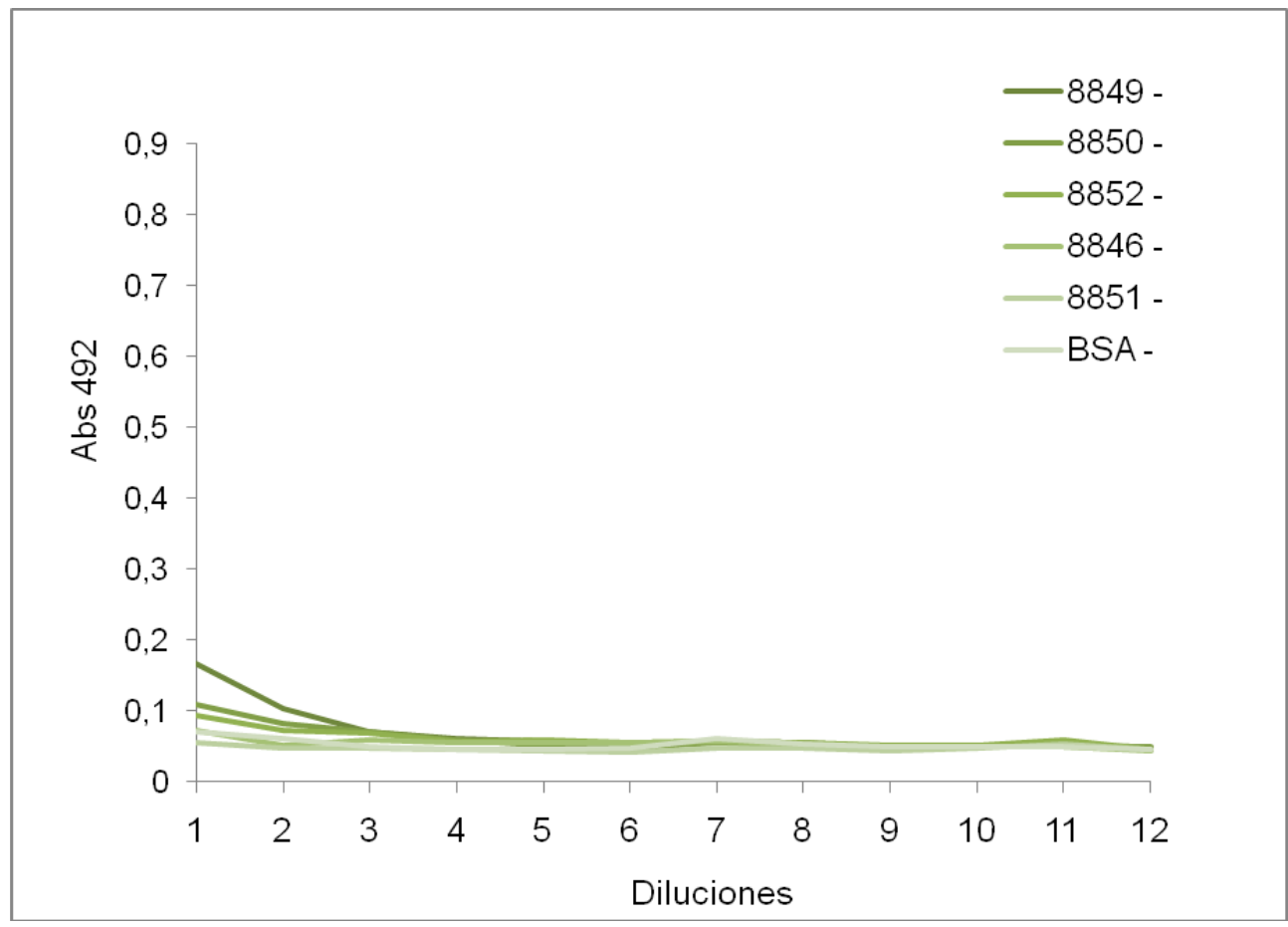

Figura 3.10B No reconocimiento de sueros de pacientes sanos contra CTB-LipL32. 


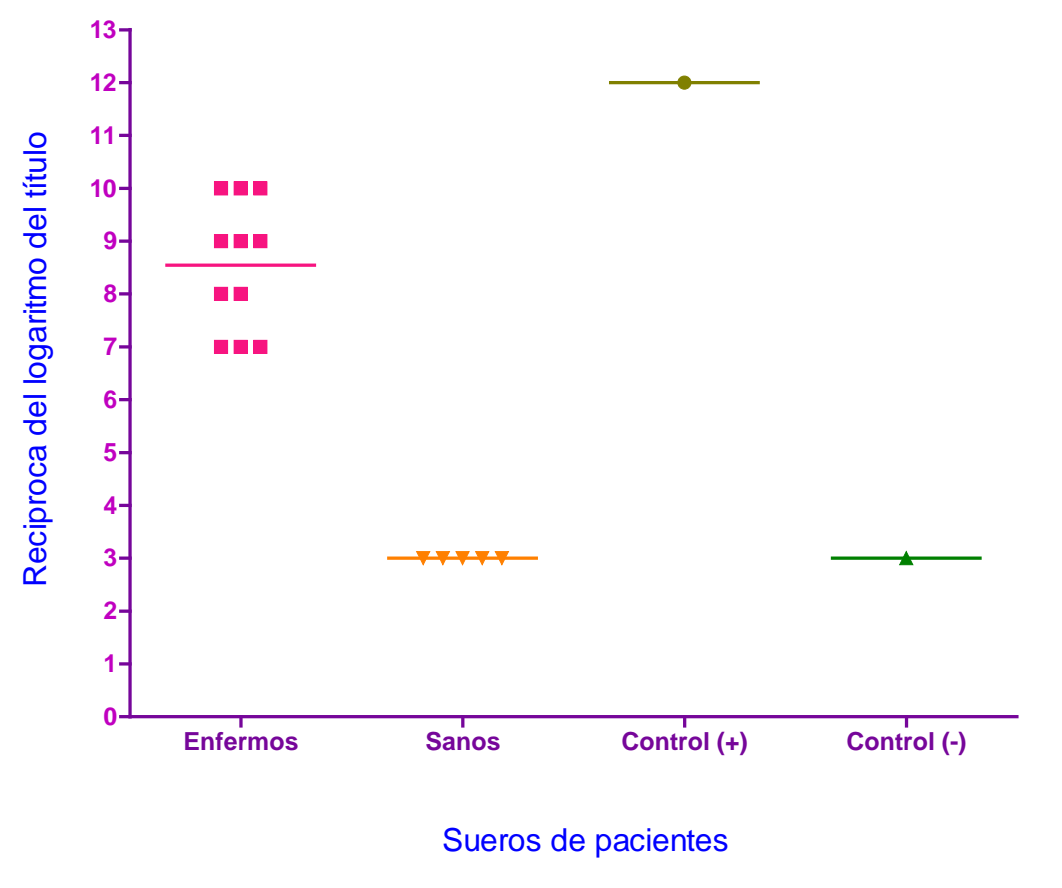

Figura 3.10C. Reactividad de sueros humanos con CTB-LipL32

\subsubsection{Inmunización y posterior desafío}

A los 4 grupos descriptos en el punto $\mathbf{2 . 2 5}$, al momento de la inoculación se agregó un quinto grupo compuesto por animales no inmunizados y desafiados con PBS, como control de la mortalidad espontanea.

\subsubsection{Mortalidad}

En el desafío pudimos corroborar que los animales no infectados con LIC sobrevivieron en su totalidad. En el otro extremo, aquellos animales no inmunizados e infectados con LIC murieron todos al cabo de 14 días PI. Por otro lado, los animales inmunizados con CTB sobrevivieron solo unos pocos días más que aquellos sin inmunización. Con respecto a la molécula CTBLipL32, resultó más eficiente en la protección contra la infección por LIC que LipL32 sola $(p=0.005)$ (Figura 3.13). 


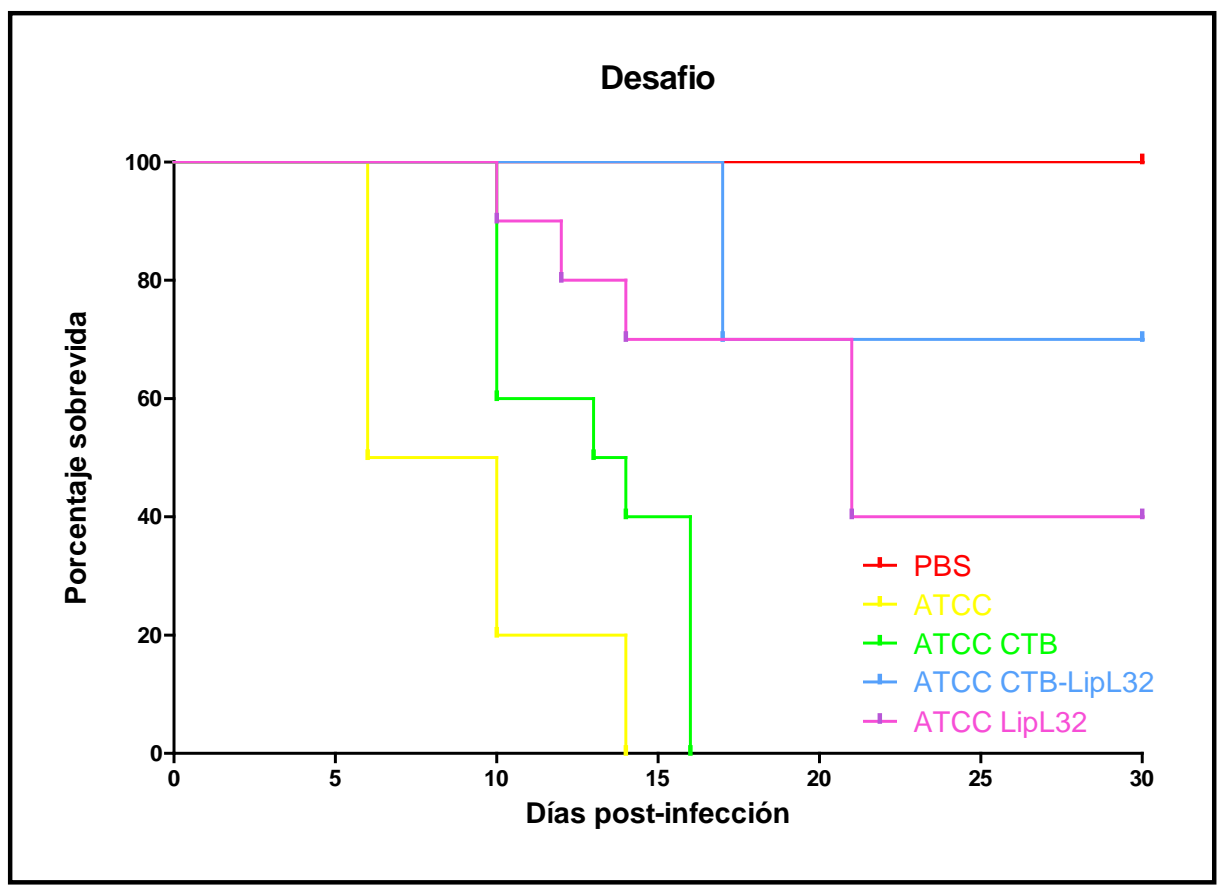

Figura 3.13. Sobrevida de hamster inmunizados y desafiados con LIC

\subsubsection{Analisis histopatológico}

De los animales desafiados se tomaron muestras de riñón, y se tiñeron con hematoxilina y eosina con el fin de comparar la patología histológica que presentaban. Se analizaron cortes de áreas corticales y medulares de riñón de hamsters con $14 \mathrm{PI}$. Los controles inoculados con PBS presentaban una histología normal. En cambio, los hamsters infectados con LIC mostraron un importante infiltrado inflamatorio con pérdida de glomérulos. Finalmente, los hamsters inoculados con LIC previamente inmunizados con CTB-LipL32 mostraron infiltrado inflamatorio más moderado con mayor conservación de glomérulos (Figura 3.14). El grupo inmunizado con CTB presentó resultados similares a los de aquellos no inmunizados e infectados mientras los inmunizados con LipL32 fueron más similares a los inmunizados con CTBLipL32 (datos no mostrados). 

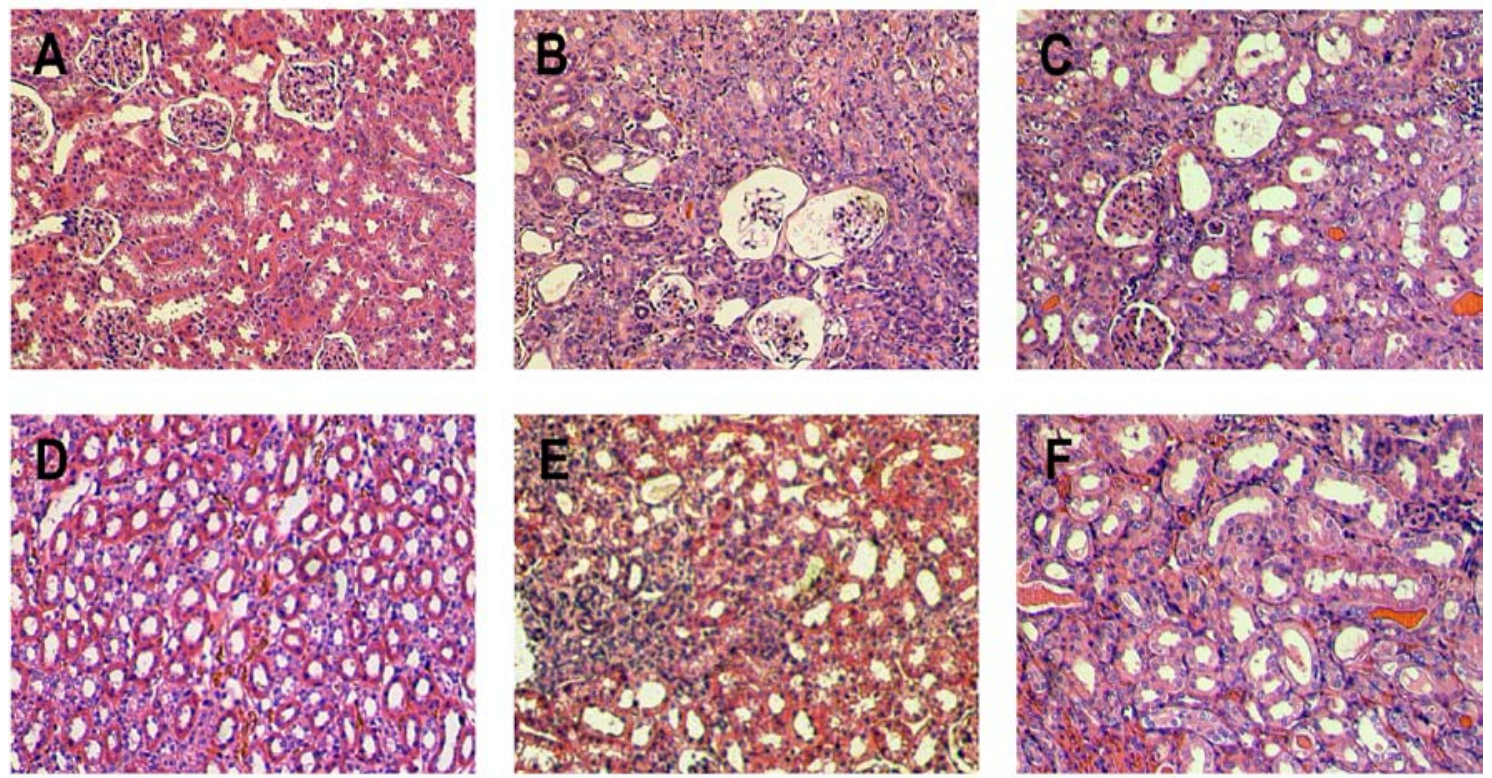

Figura 3.14. Histopatología de áreas corticales (A-C) y medulares (D-F) renales de hamsters de 3-4 semanas de edad a los 14 días PI. A y D, hamsters inoculados con PBS; B y E, hamsters inoculados con LIC; C y F, hamsters inoculados con LIC previamente inmunizados con CTB-LipL32. Tinción de hematoxilina y eosina. X200.

\subsubsection{Análisis inmunohistoquímico}

A fin de determinar la carga bacteriana a nivel de la lesión, se empleó un método semicuantitativo en base a la tinción de antígenos de LIC, por medio de la técnica inmunohistoquímica, y el análisis comparativo de los resultados en cortes de tejidos de los animales analizados a los 14 días PI. Tal como se esperaba, no se observó coloración en tejidos provenientes de animales no infectados, lo que indicó la ausencia de reactividad inespecífica por parte del pool de antisueros (Figura 3.16A). En cambio, en las muestras de los animales infectados no inmunizados, se observó una amplia distribución de antígeno de LIC, en diversas estructuras, principalmente en túbulos renales (Figura 3.16B). Las muestras tisulares de los animales inmunizados previamente a la infección mostraron una clara reducción de la tinción de antígenos de LIC (Figura 3.16C) sugiriendo fuertemente una menor carga bacteriana en los mismos. 

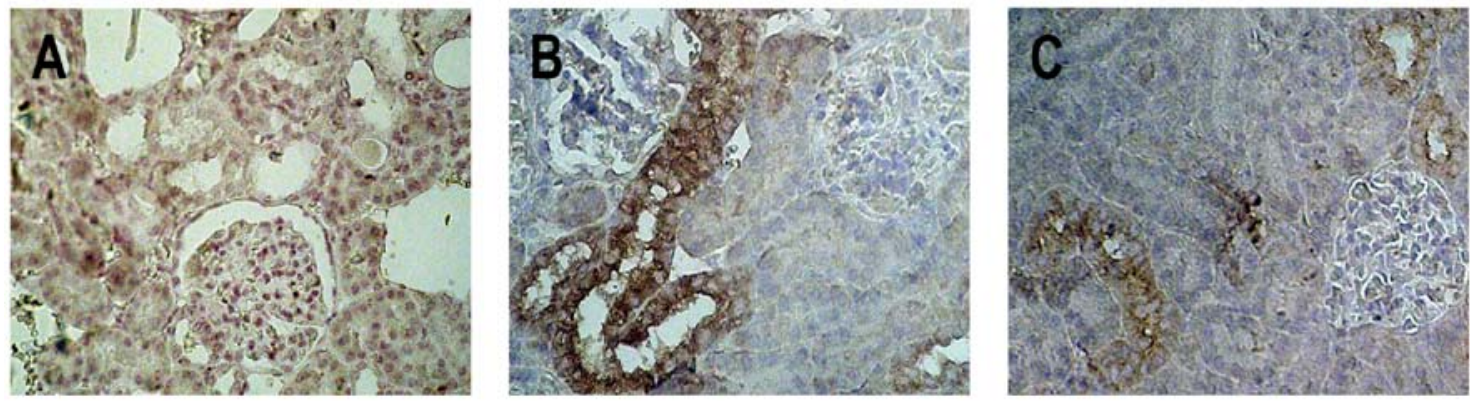

Figura 3.15. Inmunohistoquímica de áreas corticales renales de hamsters de 3-4 semanas de edad a los 14 días PI empleando un pool de antisueros contra diversas proteínas de superficie de LIC. A: hamsters inoculados con PBS presentan reducida marcación; B: hamsters inoculados con LIC muestran importante marcación específica en la luz de túbulos renales; C: hamsters inoculados con LIC previamente inmunizados con CTB-LipL32 muestran reducida marcación específica cuando comparados con $\mathrm{B}$.

\subsubsection{Analisis de la respuesta inmune humoral}

Se detecto seroconversión en los animales inmunizados con CTBLipL32 y no en los controles. Los resultados se grafican en la Figura 3.16.

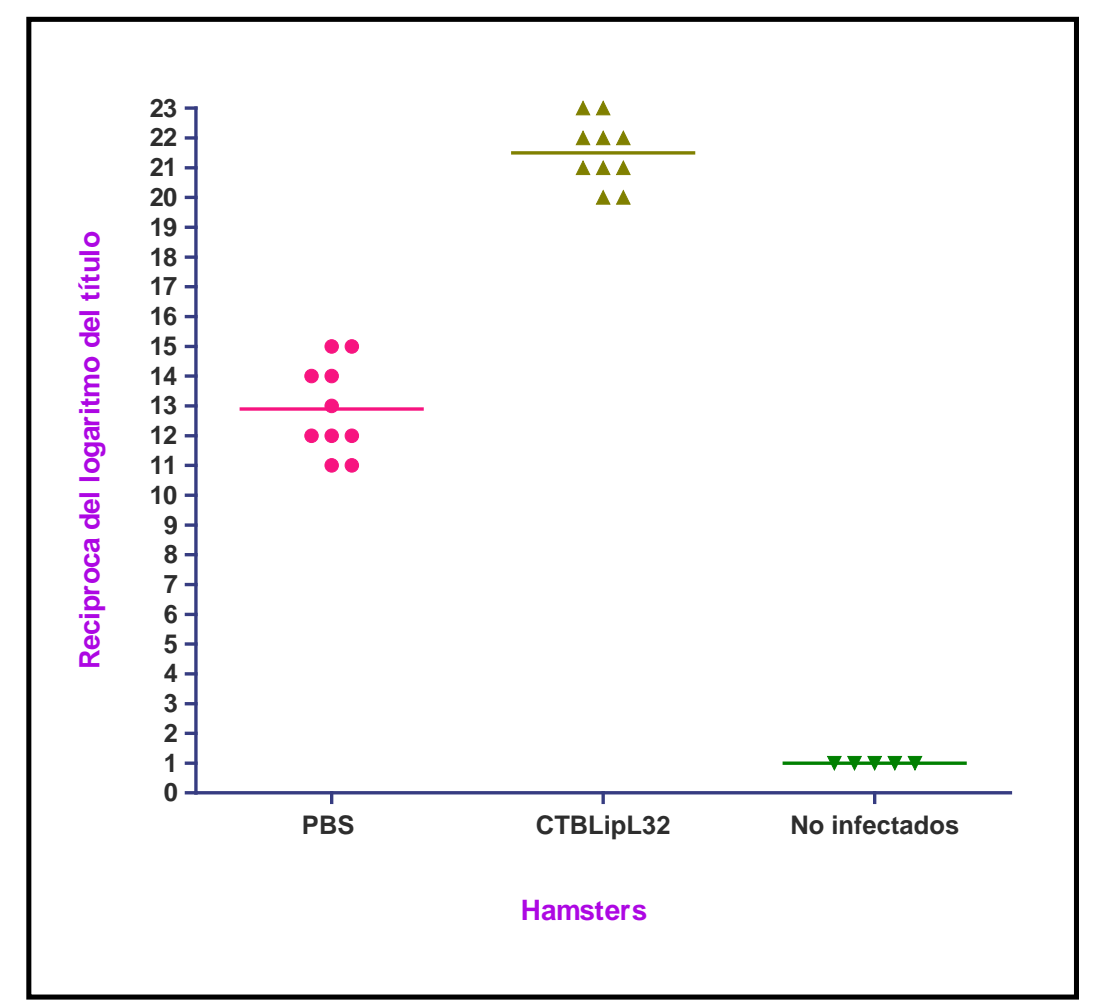

Figura 3.17 Respuesta inmune humoral. 


\section{Discusión}

\subsection{LIC10365}

Varias proteínas de superficie de membrana han sido predichas durante el proceso de anotación del genoma de L. interrogans serovar Copenhageni (83, 84), algunas de las cuales son proteínas hipotéticas de función desconocida, que, debido a su presunta localización, se cree que juegan un papel en la interacción huésped-patógeno. A la fecha, unas pocas adhesinas (complejos proteicos que reconocen y unen receptores de la superficie celular del hospedador, a la matriz extracelular o ECM) de leptospira han sido publicadas, incluyendo una proteína de $36 \mathrm{kDa}$ de identidad desconocida que puede unirse a la fibronectina identificada en la membrana externa de una cepa patogénica virulenta de leptospiras (72), una proteína de 24 kDa con capacidad de unirse a laminina denominada Lsa24 (5)/LfhA (112) y las proteínas LigA y LigB (18). Aunque se han descripto proteínas con capacidad de unión a los receptores CAM para las espiroquetas patógenas Borrelia spp y Treponema sp. (62, 64, $103,104)$, a la fecha, no se han identificado proteínas de leptospira que poseen la capacidad de inducir CAMs.

La secuencia codificante seleccionada LIC10365 es parte de una familia de genes parálogos que comprende a LIC11207, LIC10821, LIC10774 y LIC11030. Además, esta familia de proteínas comparte un dominio de función desconocida, denominado DUF 1565, que se encuentra en varias bacterias y en la archae Methanosarcina acetivorans (4, 31, 97).

El mejor score en la predicción para péptido señal de lipoproteínas (SPasell) fué obtenido en la posición 16-17 por el LipoP (31). Para la expresión procariótica recombinante, el plásmido pAE-LIC10365 fue diseñado de forma de excluir la región del péptido señal y expresar una cola N-terminal de 6 histidinas (His-tag) que permitan la rápida purificación a media escala por cromatografía de afinidad a metales.

La expresión de la proteína fue realizada utilizando una cepa de E. coli C43 (DE3), que es un mutante de las BL21(DE3) (74). Las proteínas con alto contenido de hidrofobicidad, como las globulares o las proteínas de membrana, frecuentemente exhiben un efecto tóxico que puede provocar la pérdida del plásmido o incluso la muerte celular. Se ha reportado que la cepa utilizada puede tolerar la toxicidad por aumento de la estabilidad plasmídica, 
promoviendo una mayor expresión proteica en cuerpos de inclusión, o por localizar la proteína sobreexpresada en el compartimiento de membrana (74). La proteína recombinante rLIC19365 fué expresada con el tamaño esperado de 37.7 kDa, incluso en los cuerpos de inclusión. En el análisis por SDS-PAGE, la proteína purificada apareció como una sola banda, la cual fue reconocida por los anticuerpos presentes en el suero de los ratones inmunizados con la proteína rLIC10365.

Como hecho interesante, es el hallazgo de que el gen de LIC10365 esta conservado en solo tres de las cinco cepas patogénicas de leptospira que se han analizado y ausente en la cepa no patogénica. Si bien será necesaria su confirmación futura, no es nuevo el conocimiento de la ausencia de ciertos genes en serovares de L. interrogans. Se han documentado genes que son exclusivos de los serovares Copenhageni o Lai (83). El gen de LIC10365 está presente en L. interrogans serovar Lai (92) y tiene una contraparte similar en L. borgpetersenii serovar Hardjo-Boris (14).

Las especies patogénicas de Leptospira interrogans y L. borgpetersenii combinadas abarcan 140 cepas y 125 grupos diversos antigénicos referidos como serovares (12). Como era de esperar, los transcriptos fueron detectados solamente en las cepas conteniendo el gen, indicando la expresión de su mRNA en condiciones in vitro. Además, los resultados muestran que la expresión de LIC10365 se da tanto en la infección como en el cultivo de la bacteria. Esto es particularmente importante ya que se ha visto que ciertas proteínas son expresadas bajo condiciones de cultivo y no en la infección. Por ejemplo, LipL36 se expresa altamente durante el cultivo de Leptospira Kirschneri pero no se detecta por inmunohistoquímica en riñones de hamsters infectados con la bacteria $(6,41)$. Por otro lado, LipL32 es detectada tanto por inmunohistoquímica como por inmunoblot (40).

Es importante la demostración de que una proteína hipotética se expresa durante la infección por leptospira, lo que implica que en cierta medida es necesaria para la infección. Los resultados de la inmunohistoquímica muestran que la proteína codificada por el gen de LIC10365, es expresada por L. interrogans dentro de los túbulos renales de cobayos infectados así de forma similar a Ompl1, LipL41 y LipL32 entre otras (6). 
La activación en la expresión de las moléculas de superficie ICAM-1 y Eselectina fue observada luego del tratamiento de los cultivos de células endoteliales con rLIC10365. El bajo nivel de lipopolisacáridos en la muestra proteica (1.2 × $\left.10^{-2} \mu \mathrm{g} \mathrm{mL}-1\right)$, más el tratamiento de las muestras con el antibiótico polimixina $\mathrm{B}$ y además el hecho que otra proteína recombinante (rLIC10793), con un contenido similar de polisacáridos, no indujera la expresión de CAMs en HUVECs, prácticamente excluye la posibilidad de interferencia de polisacáridos en el resultado provenientes de E. coli.

En un trabajo anterior, Sellati y col. (103) hallaron que solo la forma lipídica de la proteína OspA de Borrelia burgdoferi fue capaz de promover la activación de la expresión de ICAM-1 y de E-selectina. En contraste, en este caso esta activación fue independiente de la forma lipídica de la proteína en HUVECs, sugiriendo que en este modelo experimental la parte lipídica no está involucrada en esta interacción.

Estos resultados indican que rLIC10365 desencadena la activación en células endoteliales de la expresión de ICAM-1 y de E-selectina, las cuales son moléculas de adhesión esenciales para la interacción entre células con la matriz extracelular y para el reclutamiento y migración de los neutrófilos a través del endotelio.

Es conocido que varias bacterias patogénicas infectan los tejidos del huésped por medio de su capacidad de unión a CAMs utilizando a estos receptores como transporte.

Basados en el hecho de que rLIC10365 se expresa durante la infección, se puede especular con la posibilidad de que la proteína codificada por el gen de LIC10365 cumpla un papel importante en la patogénesis activando la expresión durante la infección de los receptores celulares.

La activación de la expresión de las moléculas de adhesión, ICAM-1 y Eselectina, en las células endoteliales, podría ser uno de los mecanismos de la inflamación característica del endotelio dañado que se observa en la leptospirosis.

\subsection{CTB-LipL32}

La variabilidad de expresión proteica entre serovares y la habilidad de regulación de la expresión proteica de un mismo serovar en diferentes 
ambientes ya sea en cultivo in vitro o durante la infección del huésped ha dificultado la búsqueda de un candidato vacunal que sea de amplio espectro dentro del género como para cubrir a la mayoría de las especies de leptospiras patogénicas que existen.

LipL32 es la lipoproteína de mayor abundancia en la membrana externa de leptospiras, se expresa en altos niveles tanto en cultivos in vitro como durante la infección, su secuencia aminoacídica se encuentra muy conservada entre las especies patogénicas (40), y recientemente se le ha atribuido que media en la interacción de la bacteria con el colágeno IV y la fibronectina plasmática (45), sugiriendo fuertemente un papel importante en la patogénesis. Por otro lado se comprobó que junto con las proteínas de shock térmico GroEl y DnaK, LipL32 es una de las proteínas más reconocidas por el sistema inmune, es decir que presenta reactividad inmuno dominante, durante la infección. En esta circunstancia, LipL32 se detecta dentro de los túbulos renales y en el suero de pacientes infectados hay gran cantidad de anticuerpos que responden contra ella (40). En efecto, se ha visto que los sueros de pacientes con leptospirosis reaccionan con mayor frecuencia (84\%) que con otros antígenos. Actualmente, es el marcador serológico más importante en análisis de leptospirosis por inmunoblots. Presenta alta especificidad como indicador para el diagnóstico específico de leptospirosis ya que no se ha encontrado homología con otras proteínas bacterianas por BLAST y presenta entre un 0 y $5 \%$ de background en los controles que incluyen aquellos de zonas con alta y baja incidencia de leptospirosis (39). Estas características han convertido a LipL32 en un excelente candidato vacunal. Más aún, utilizando un vector de adenovirus conteniendo el gen de LipL32 obtenido de L. Autumnales, se pudo comprobar que fué capaz de inducir protección cruzada en gerbos inmunizados ante el desafío con L. Interrogans (11).

Nuestra aproximación contempló la clonación de LipL32 en el vector de expresión PAE-CTB de forma que la proteína recombinante resultante fue una quimera entre las dos.

CTB-LipL32 se expresó tanto en la cepa BL21 (DE3) como en la Sl. Ambas cepas contienen a la polimerasa del fago $\mathrm{T} 7$ incluida en su genoma bajo un promotor inducible con IPTG en el caso de las DE3 y con $\mathrm{NaCl}$ para las $\mathrm{SI}$. Si bien en ambas se logró una buena concentración de proteína recombinante 
luego de 4 hs de inducción, tanto en forma soluble como en cuerpos de inclusión, se opto por la cepa SI ya que presentó una menor velocidad de inducción que favoreció una mayor concentración de proteína en forma soluble, facilitando la posterior purificación al evitar el replegado de la misma. La observación de cierto grado de expresión basal de la proteína recombinante en las muestras no inducidas se debió probablemente a que el sistema produce una expresión basal de T7 aún en ausencia del inductor.

La proteína fue expresada con el tamaño esperado de $45 \mathrm{kDa}$. En el análisis por SDS-PAGE la proteína purificada apareció como una sola banda, la cual fue reconocida por los anticuerpos anti LipL32 y anti CTB en los ensayos de inmunoblot confirmando su identidad.

La fusión del antígeno con el adyuvante facilitó la producción ya que la administración y la relación de concentraciones entre ambos fué siempre la misma. Cada pentámero de CTB llevó unidos 5 moléculas de antígeno y fué capaz de unirse a su receptor, el gangliósido GM1, lo cual se verificó por 2 métodos distintos. El primero tuvo como objetivo verificar su conformación pentamérica, utilizando electroforesis en poliacrilamida en condiciones nativas o desnaturalizantes. De esta forma, pudo visualizarse en condiciones nativas una banda que correspondería a la proteína en su estado pentamérico. En contraste, en aquel gel efectuado en condiciones desnaturalizantes sólo pudo observarse la proteína en su estado monomérico. En segundo lugar, se realizó un ELISA a fin de corroborar la unión de CTB-LipL32 con el gangliósido GM1, y comprobando indirectamente el correcto plegado del pentámero de CTB-LipL32 ya que solo en su forma pentamérica puede unirse a su receptor (22).

La inmunización de ratones con CTB-LipL32 y la verificación de la seroconvertivilidad en los mismos, demostró en primera instancia, las capacidades antigénicas de esta proteína. Esto fue posteriormente ratificado cuando los sueros de pacientes convalecientes fueron capaces de reconocer a CTB-LipL32 demostrando que LipL32 queda conformacionalmente expuesta en la configuración tridimensional. A su vez, valida a esta misma proteína recombinante como un antígeno de utilidad para la realización de inmunoensayos con fines diagnósticos.

En cuanto a su capacidad protectora, nuestros experimentos demostraron que CTB-LipL32 fué capaz de inducir una protección parcial aunque 
estadísticamente significativa. Esta protección obtuvo un correlato en la histopatología observada a nivel renal en los diversos grupos ya que la injuria fue menor en las muestras de aquellos animales que habían sido inmunizados previamente con CTB-LipL32 así como en la menor carga bacteriana detectada por IHQ. Es de destacar que LipL32 indujo más protección fusionada a CTB que cuando se la utilizó sola para inmunizar.

Recientemente, se ha reportado un estudio donde se ha inmunizado a hamsters con recombinantes de Mycobacterium bovis (BCG) expresando la proteína LipL32 y posteriormente se lo ha desafiado con $10^{2}$ LIC (Fiocruz L1130). Los porcentajes de sobrevida que se observaron fueron del 50-60\%. Comparado con nuestros resultados de sobrevida del $70 \%$, los resultados son similares, pero esta diferencia podría ser mayor dado que nosotros desafiamos con $10^{3.5}$ LIC (misma cepa). En contraste, en el mencionado estudio no observaron evidencias microscópicas de la enfermedad en los tejidos de aquellos animales que fueron sacrificados luego de 28 días PI, ni signos de enfermedad durante el desafío (102). Esta diferencia podría deberse al diferente carrier utilizado para presentar LipL32 al sistema inmune del huésped. En este sentido, es posible que el contexto BCG mejore el componente celular de la respuesta y por lo tanto se observen menos lesiones en el periodo subagudo.

El poder adyuvante de la toxina colérica fué inicialmente atribuido a su actividad catalítica enzimática (69), pero posteriormente se demostró que esta no es absolutamente requerida para modular cualquier efecto inmune de la toxina. En mutantes sin actividad catalítica pero con preservación de la estructura se vio que la subunidad B de CT retiene la capacidad de inducir una respuesta específica en varios niveles de antígenos no relacionados $(23,32$, 118).

Si bien no se conoce todavía como es el mecanismo por el cual CTB influye en la respuesta inmune, hay varios datos en los últimos años que aportan algo de luz al tema.

La función de su receptor, el gangliósido GM1, es también poco conocida, pero se lo ha implicado en varias rutas de transducción de señales. Por ejemplo, el GM1 exógeno afecta a la señalización de Ca2+ (48), a la modulación de la 
expresión de $\operatorname{CD} 4(77,78)$ y a la modulación en la actividad tirosina-kinasa del factor de crecimiento epidérmico (116).

En el caso de CTB, se ha reportado que incrementa la fosforilación de MEK1/2, Erk1/2 y p38, lo que se correlaciona con la actividad enzimática de estas kinasas. Además, CTB induce la fosforilación de p90rsk, un blanco directo de Erk1/2. Sin embargo, la inhibición de MEK1/2 tendría poco efecto en el incremento en la expresión de CD86, CD14, CD69 y CD40 en macrófagos, indicando que CTB utilizaría otra vía para generar esta repuesta (98).

La estimulación de Erk1/2 por CTB regularía la expresión de moléculas de superficie involucradas en la presentación de antígenos y el incremento de liberación de IL-6, citoquina producida por muchos tipos celulares como macrófagos, células dendríticas, linfocitos $T$ y $B$, fibroblastos y hepatocitos, en el inicio de la respuesta inmune ante patógenos (98).

Interesantemente, CTB puede por sí misma inducir transactivación del factor de transcripción NF-KB en macrófagos y elevar el nivel nuclear del mismo en linfocitos $\mathrm{B}$ de bazo. El factor NF-kB ha sido implicado en la regulación de la respuesta inmune innata, incluyendo la secreción de citoquinas proinflamatorias (43).

El gangliósido GM1 se localiza en los lipid rafts que son dominios ricos en colesterol de la membrana plasmática resistentes a la solubilización por detergentes. Es cada vez más aparente que estos dominios tendrían un importante papel en la organización de la transducción de señales a la célula desde el medio extracelular. Por ejemplo, el receptor de la célula B esta fuera de los rafts en células $B$ en reposo, pero se mueve rápidamente a los rafts luego de la activación del receptor (17). En este contexto, será importante investigar la influencia que la unión de CTB a GM1 posee sobre la organización de las respuestas moleculares dentro de los raft. Con un conocimiento mayor de los mecanismos por los que la unión de CTB con su receptor ejerce su influencia sobre la respuesta celular, podremos tomar mayores ventajas de esta respuesta inmune innata y mejorar la inmunidad en la vacunación con la misma. 


\section{Conclusiones}

- La proteína hipotética LIC10365 es una lipoproteína real de la membrana externa de LIC.

- LIC10365 está conservada en varias cepas patógenas y ausente en la saprofita.

- LIC10365 puede actuar sobre las células endoteliales del huésped induciendo la expresión de moléculas de adhesión celular (ICAM-1 y Eselectina) lo cual podría tener importante participación en la patogénesis.

- Se logró expresar la proteína LipL32, mayoritaria de la membrana externa de leptospira, en fusión con CTB, que tiene alto poder adyuvante por su habilidad para unirse al gangliósido GM1, presente en los lipid rafts y participante en varias rutas de señalización celular.

- Se comprobó que CTB-LipL32 puede ser un componente importante para un kit de diagnóstico para leptospira ya que fué reconocida por los sueros de pacientes convalecientes y no reconocida por aquellos sueros de pacientes sanos.

- Se comprobó que CTB-LipL32 podría ser un componente importante para una vacuna acelular contra la leptospirosis ya que tanto en los desafíos como en los cortes histológicos se pudo comprobar el papel de adyuvante de CTB, ya que la protección ante la infección es notablemente superior en aquellos animales inmunizados con CTB-LipL32, que en aquellos inmunizados con cada componente por separado. 


\section{Referencias}

1. Abb, J. 2002. Acute leptospirosis in a triathlete. Wilderness Environ Med 13:45-7.

2. Adu-Bobie, J., B. Capecchi, D. Serruto, R. Rappuoli, and M. Pizza. 2003. Two years into reverse vaccinology. Vaccine 21:605-10.

3. Alfonso, H. C., O. C. Gomez, L. M. Fonte, and Q. P. Quintana. 2005. [Isolation of a strain from the Bataviae pathogenic complex in patient vaccinated against copenhageni, canicola and mozdok]. Rev Cubana Med Trop 57:73-4.

4. Altschul, S. F., T. L. Madden, A. A. Schaffer, J. Zhang, Z. Zhang, W. Miller, and D. J. Lipman. 1997. Gapped BLAST and PSI-BLAST: a new generation of protein database search programs. Nucleic Acids Res 25:3389-402.

5. Barbosa, A. S., P. A. Abreu, F. O. Neves, M. V. Atzingen, M. M. Watanabe, M. L. Vieira, Z. M. Morais, S. A. Vasconcellos, and A. L. Nascimento. 2006. A newly identified leptospiral adhesin mediates attachment to laminin. Infect Immun 74:6356-64.

6. Barnett, J. K., D. Barnett, C. A. Bolin, T. A. Summers, E. A. Wagar, N. F. Cheville, R. A. Hartskeerl, and D. A. Haake. 1999. Expression and distribution of leptospiral outer membrane components during renal infection of hamsters. Infect Immun 67:853-61.

7. Barocchi, M. A., A. I. Ko, S. R. Ferrer, M. T. Faria, M. G. Reis, and L. W. Riley. 2001. Identification of new repetitive element in Leptospira interrogans serovar copenhageni and its application to PCR-based differentiation of Leptospira serogroups. J Clin Microbiol 39:191-5.

8. Bastiaens, P. I., I. V. Majoul, P. J. Verveer, H. D. Soling, and T. M. Jovin. 1996. Imaging the intracellular trafficking and state of the AB5 quaternary structure of cholera toxin. EMBO J 15:4246-53.

9. Bendtsen, J. D., H. Nielsen, G. von Heijne, and S. Brunak. 2004. Improved prediction of signal peptides: SignalP 3.0. J Mol Biol 340:78395.

10. Boyle, E. C., and B. B. Finlay. 2003. Bacterial pathogenesis: exploiting cellular adherence. Curr Opin Cell Biol 15:633-9.

11. Branger, C., C. Sonrier, B. Chatrenet, B. Klonjkowski, N. RuvoenClouet, A. Aubert, G. Andre-Fontaine, and M. Eloit. 2001. Identification of the hemolysis-associated protein 1 as a cross-protective immunogen of Leptospira interrogans by adenovirus-mediated vaccination. Infect Immun 69:6831-8.

12. Brenner, D. J., A. F. Kaufmann, K. R. Sulzer, A. G. Steigerwalt, F. C. Rogers, and R. S. Weyant. 1999. Further determination of DNA relatedness between serogroups and serovars in the family Leptospiraceae with a proposal for Leptospira alexanderi sp. nov. and four new Leptospira genomospecies. Int J Syst Bacteriol 49 Pt 2:839-58.

13. Bulach, D. M., T. Kalambaheti, A. de la Pena-Moctezuma, and B. Adler. 2000. Functional analysis of genes in the rfb locus of Leptospira borgpetersenii serovar Hardjo subtype Hardjobovis. Infect Immun 68:3793-8. 
14. Bulach, D. M., R. L. Zuerner, P. Wilson, T. Seemann, A. McGrath, P. A. Cullen, J. Davis, M. Johnson, E. Kuczek, D. P. Alt, B. PetersonBurch, R. L. Coppel, J. I. Rood, J. K. Davies, and B. Adler. 2006. Genome reduction in Leptospira borgpetersenii reflects limited transmission potential. Proc Natl Acad Sci U S A 103:14560-5.

15. Bunikis, J., and A. G. Barbour. 1999. Access of antibody or trypsin to an integral outer membrane protein (P66) of Borrelia burgdorferi is hindered by Osp lipoproteins. Infect Immun 67:2874-83.

16. Chee, H. D., G. J. Ossenkoppele, W. Bronsveld, and L. G. Thijs. 1985. Adult respiratory distress syndrome in leptospira icterohaemorrhagiae infection. Intensive Care Med 11:254-6.

17. Cheng, P. C., M. L. Dykstra, R. N. Mitchell, and S. K. Pierce. 1999. A role for lipid rafts in $B$ cell antigen receptor signaling and antigen targeting. J Exp Med 190:1549-60.

18. Choy, H. A., M. M. Kelley, T. L. Chen, A. K. Moller, J. Matsunaga, and D. A. Haake. 2007. Physiological osmotic induction of Leptospira interrogans adhesion: LigA and LigB bind extracellular matrix proteins and fibrinogen. Infect Immun 75:2441-50.

19. Cullen, P. A., D. A. Haake, and B. Adler. 2004. Outer membrane proteins of pathogenic spirochetes. FEMS Microbiol Rev 28:291-318.

20. Cullen, P. A., D. A. Haake, D. M. Bulach, R. L. Zuerner, and B. Adler. 2003. LipL21 is a novel surface-exposed lipoprotein of pathogenic Leptospira species. Infect Immun 71:2414-21.

21. Czerkinsky, C., M. W. Russell, N. Lycke, M. Lindblad, and J. Holmgren. 1989. Oral administration of a streptococcal antigen coupled to cholera toxin B subunit evokes strong antibody responses in salivary glands and extramucosal tissues. Infect Immun 57:1072-7.

22. De Wolf, M. J., M. Fridkin, M. Epstein, and L. D. Kohn. 1981. Structure-function studies of cholera toxin and its A and B protomers. Modification of tryptophan residues. J Biol Chem 256:5481-8.

23. Douce, G., M. Fontana, M. Pizza, R. Rappuoli, and G. Dougan. 1997. Intranasal immunogenicity and adjuvanticity of site-directed mutant derivatives of cholera toxin. Infect Immun 65:2821-8.

24. Dupont, H., D. Dupont-Perdrizet, J. L. Perie, S. Zehner-Hansen, B. Jarrige, and J. B. Daijardin. 1997. Leptospirosis: prognostic factors associated with mortality. Clin Infect Dis 25:720-4.

25. Edwards, C. N., and P. N. Levett. 2004. Prevention and treatment of leptospirosis. Expert Rev Anti Infect Ther 2:293-8.

26. Faine, S., B. Adler, and C. Bolin. 1999. Leptospira and Leptospirosis, vol. 2nd Ed MediSci, Melbourne Australia.

27. Feigin, R. D., and D. C. Anderson. 1975. Human leptospirosis. CRC Crit Rev Clin Lab Sci 5:413-67.

28. Field, M. 1993. Intestinal electrolyte secretion. History of a paradigm. Arch Surg 128:273-8.

29. Finkelstein, R. A., M. Boesman, S. H. Neoh, M. K. LaRue, and R. Delaney. 1974. Dissociation and recombination of the subunits of the cholera enterotoxin (choleragen). J Immunol 113:145-50.

30. Finlay, B. B., and P. Cossart. 1997. Exploitation of mammalian host cell functions by bacterial pathogens. Science 276:718-25. 
31. Finn, R. D., J. Mistry, B. Schuster-Bockler, S. Griffiths-Jones, V. Hollich, T. Lassmann, S. Moxon, M. Marshall, A. Khanna, R. Durbin, S. R. Eddy, E. L. Sonnhammer, and A. Bateman. 2006. Pfam: clans, web tools and services. Nucleic Acids Res 34:D247-51.

32. Fontana, M. R., R. Manetti, V. Giannelli, C. Magagnoli, A. Marchini, R. Olivieri, M. Domenighini, R. Rappuoli, and M. Pizza. 1995. Construction of nontoxic derivatives of cholera toxin and characterization of the immunological response against the A subunit. Infect Immun 63:2356-60.

33. Fraser, C. M., S. Casjens, W. M. Huang, G. G. Sutton, R. Clayton, R. Lathigra, O. White, K. A. Ketchum, R. Dodson, E. K. Hickey, M. Gwinn, B. Dougherty, J. F. Tomb, R. D. Fleischmann, D. Richardson, J. Peterson, A. R. Kerlavage, J. Quackenbush, S. Salzberg, M. Hanson, R. van Vugt, N. Palmer, M. D. Adams, J. Gocayne, J. Weidman, T. Utterback, L. Watthey, L. McDonald, P. Artiach, C. Bowman, S. Garland, C. Fuji, M. D. Cotton, K. Horst, K. Roberts, B. Hatch, H. O. Smith, and J. C. Venter. 1997. Genomic sequence of a Lyme disease spirochaete, Borrelia burgdorferi. Nature 390:580-6.

34. Fraser, C. M., S. J. Norris, G. M. Weinstock, O. White, G. G. Sutton, R. Dodson, M. Gwinn, E. K. Hickey, R. Clayton, K. A. Ketchum, E. Sodergren, J. M. Hardham, M. P. McLeod, S. Salzberg, J. Peterson, H. Khalak, D. Richardson, J. K. Howell, M. Chidambaram, T. Utterback, L. McDonald, P. Artiach, C. Bowman, M. D. Cotton, C. Fujii, S. Garland, B. Hatch, K. Horst, K. Roberts, M. Sandusky, J. Weidman, H. O. Smith, and J. C. Venter. 1998. Complete genome sequence of Treponema pallidum, the syphilis spirochete. Science 281:375-88.

35. Gamberini, M., R. M. Gomez, M. V. Atzingen, E. A. Martins, S. A. Vasconcellos, E. C. Romero, L. C. Leite, P. L. Ho, and A. L. Nascimento. 2005. Whole-genome analysis of Leptospira interrogans to identify potential vaccine candidates against leptospirosis. FEMS Microbiol Lett 244:305-13.

36. George-Chandy, A., K. Eriksson, M. Lebens, I. Nordstrom, E. Schon, and J. Holmgren. 2001. Cholera toxin B subunit as a carrier molecule promotes antigen presentation and increases CD40 and CD86 expression on antigen-presenting cells. Infect Immun 69:5716-25.

37. Goldstein, R. E., R. C. Lin, C. E. Langston, P. V. Scrivani, H. N. Erb, and S. C. Barr. 2006. Influence of infecting serogroup on clinical features of leptospirosis in dogs. J Vet Intern Med 20:489-94.

38. Guedes e Silva, J. B., L. M. Paiva, J. J. Pereira da Silva, and B. A. de Souza Netto. 1980. Pathological involvement of human gastrocnemius muscle in leptospirosis (a study in 63 patients). Rev Bras Pesqui Med Biol 13:9-13.

39. Guerreiro, H., J. Croda, B. Flannery, M. Mazel, J. Matsunaga, M. Galvao Reis, P. N. Levett, A. I. Ko, and D. A. Haake. 2001. Leptospiral proteins recognized during the humoral immune response to leptospirosis in humans. Infect Immun 69:4958-68.

40. Haake, D. A., G. Chao, R. L. Zuerner, J. K. Barnett, D. Barnett, M. Mazel, J. Matsunaga, P. N. Levett, and C. A. Bolin. 2000. The 
leptospiral major outer membrane protein LipL32 is a lipoprotein expressed during mammalian infection. Infect Immun 68:2276-85.

41. Haake, D. A., C. Martinich, T. A. Summers, E. S. Shang, J. D. Pruetz, A. M. McCoy, M. K. Mazel, and C. A. Bolin. 1998. Characterization of leptospiral outer membrane lipoprotein LipL36: downregulation associated with late-log-phase growth and mammalian infection. Infect Immun 66:1579-87.

42. Haake, D. A., M. K. Mazel, A. M. McCoy, F. Milward, G. Chao, J. Matsunaga, and E. A. Wagar. 1999. Leptospiral outer membrane proteins OmpL1 and LipL41 exhibit synergistic immunoprotection. Infect Immun 67:6572-82.

43. Hanada, T., and A. Yoshimura. 2002. Regulation of cytokine signaling and inflammation. Cytokine Growth Factor Rev 13:413-21.

44. Hasnain, S. E., and N. Ahmed. 2004. Leptospirosis. Lancet Infect Dis 4:543; discussion 544.

45. Hauk, P., F. Macedo, E. C. Romero, S. A. Vasconcellos, Z. M. de Morais, A. S. Barbosa, and P. L. Ho. 2008. In LipL32, the major leptospiral lipoprotein, the $\mathrm{C}$ terminus is the primary immunogenic domain and mediates interaction with collagen IV and plasma fibronectin. Infect Immun 76:2642-50.

46. Hazes, B., and R. J. Read. 1997. Accumulating evidence suggests that several AB-toxins subvert the endoplasmic reticulum-associated protein degradation pathway to enter target cells. Biochemistry 36:11051-4.

47. Heisey, G. B., S. Nimmanitya, C. Karnchanachetanee, M. Tingpalapong, S. Samransamruajkit, P. Hansukjariya, M. R. Elwell, and G. S. Ward. 1988. Epidemiology and characterization of leptospirosis at an urban and provincial site in Thailand. Southeast Asian J Trop Med Public Health 19:317-22.

48. Hilbush, B. S., and J. M. Levine. 1992. Modulation of a Ca2+ signaling pathway by GM1 ganglioside in PC12 cells. J Biol Chem 267:24789-95.

49. Hirst, T. R. 1995. Bacterial toxins \& Virulence factors in disease, p. 123184. In J. Moss, M. Vaughan, B. Igleweski, and N. Tu (ed.). Marcel Dekker, New York.

50. Ho, K. J., and K. T. Scully. 1980. Acute rhabdomyolysis and renal failure in Weil's disease. Ala J Med Sci 17:133-7.

51. Holmgren, J., C. Czerkinsky, J.-B. Sun, and A.-M. Svennerholm. 1996. Oral vaccination, mucosal immunity and oral tolerance with special reference to cholera toxin, p. 437-458. In S. H. E. Kaufmann (ed.), Concepts in vaccine development. Walter de Gruyter, Berlin, Germany.

52. Jaffe, E. A., R. L. Nachman, C. G. Becker, and C. R. Minick. 1973. Culture of human endothelial cells derived from umbilical veins. Identification by morphologic and immunologic criteria. J Clin Invest 52:2745-56.

53. Juncker, A. S., H. Willenbrock, G. Von Heijne, S. Brunak, H. Nielsen, and A. Krogh. 2003. Prediction of lipoprotein signal peptides in Gramnegative bacteria. Protein Sci 12:1652-62.

54. Kassis, S., J. Hagmann, P. H. Fishman, P. P. Chang, and J. Moss. 1982. Mechanism of action of cholera toxin on intact cells. Generation of A1 peptide and activation of adenylate cyclase. J Biol Chem 257:1214852. 
55. Kerr, J. R. 1999. Cell adhesion molecules in the pathogenesis of and host defence against microbial infection. Mol Pathol 52:220-30.

56. King, C. A., and W. E. Van Heyningen. 1973. Deactivation of cholera toxin by a sialidase-resistant monosialosylganglioside. J Infect Dis 127:639-47.

57. Ko, A. I., M. Galvao Reis, C. M. Ribeiro Dourado, W. D. Johnson, Jr., and L. W. Riley. 1999. Urban epidemic of severe leptospirosis in Brazil. Salvador Leptospirosis Study Group. Lancet 354:820-5.

58. Kobayashi, Y. 2001. Clinical observation and treatment of leptospirosis. $\mathrm{J}$ Infect Chemother 7:59-68.

59. Koizumi, N., H. Watanabe, T. J. John, Y. Kobayashi, S. N. Ahmad, S. Shah, F. M. Ahmad, S. R. Rathinam, S. Visith, P. Kearkiat, A. M. Bal, E. R. Cachay, J. M. Vinetz, S. Thybo, A. J. McBride, D. A. Athanazio, M. G. Reis, A. I. Ko, T. K. Dutta, M. Christopher, N. Koizumi, H. Watanabe, W. Tangkanakul, H. L. Smits, S. Jatanasen, D. A. Ashford, and R. Higgins. 2005. Leptospirosis vaccines: past, present, and future. J Postgrad Med 51:210-4.

60. Krick, W. K. 1984. Prophylaxis against leptospirosis with doxycycline. N Engl J Med 311:54.

61. Lai, K. N., I. Aarons, A. J. Woodroffe, and A. R. Clarkson. 1982. Renal lesions in leptospirosis. Aust N Z J Med 12:276-9.

62. Lee, K. H., H. J. Choi, M. G. Lee, and J. B. Lee. 2000. Virulent Treponema pallidum $47 \mathrm{kDa}$ antigen regulates the expression of cell adhesion molecules and binding of T-lymphocytes to cultured human dermal microvascular endothelial cells. Yonsei Med J 41:623-33.

63. Lee, R. E., S. I. Terry, T. M. Walker, and A. E. Urquhart. 1981. The chest radiograph in leptospirosis in Jamaica. Br J Radiol 54:939-43.

64. Lee, S. H., K. K. Kim, and B. K. Choi. 2005. Upregulation of intercellular adhesion molecule 1 and proinflammatory cytokines by the major surface proteins of Treponema maltophilum and Treponema lecithinolyticum, the phylogenetic group IV oral spirochetes associated with periodontitis and endodontic infections. Infect Immun 73:268-76.

65. Lencer, W. I., C. Constable, S. Moe, M. G. Jobling, H. M. Webb, S. Ruston, J. L. Madara, T. R. Hirst, and R. K. Holmes. 1995. Targeting of cholera toxin and Escherichia coli heat labile toxin in polarized epithelia: role of COOH-terminal KDEL. J Cell Biol 131:951-62.

66. Levett, P. N. 2001. Leptospirosis. Clin Microbiol Rev 14:296-326.

67. Levett, P. N. 2003. Usefulness of serologic analysis as a predictor of the infecting serovar in patients with severe leptospirosis. Clin Infect Dis 36:447-52.

68. Lipscombe, M., I. G. Charles, M. Roberts, G. Dougan, J. Tite, and N. F. Fairweather. 1991. Intranasal immunization using the B subunit of the Escherichia coli heat-labile toxin fused to an epitope of the Bordetella pertussis P.69 antigen. Mol Microbiol 5:1385-92.

69. Lycke, N., T. Tsuji, and J. Holmgren. 1992. The adjuvant effect of Vibrio cholerae and Escherichia coli heat-labile enterotoxins is linked to their ADP-ribosyltransferase activity. Eur J Immunol 22:2277-81.

70. McBride, A. J., D. A. Athanazio, M. G. Reis, and A. I. Ko. 2005. Leptospirosis. Curr Opin Infect Dis 18:376-86. 
71. McKenzie, S. J., and J. F. Halsey. 1984. Cholera toxin B subunit as a carrier protein to stimulate a mucosal immune response. J Immunol 133:1818-24.

72. Merien, F., J. Truccolo, G. Baranton, and P. Perolat. 2000. Identification of a $36-\mathrm{kDa}$ fibronectin-binding protein expressed by a virulent variant of Leptospira interrogans serovar icterohaemorrhagiae. FEMS Microbiol Lett 185:17-22.

73. Merritt, E. A., and W. G. Hol. 1995. AB5 toxins. Curr Opin Struct Biol 5:165-71.

74. Miroux, B., and J. E. Walker. 1996. Over-production of proteins in Escherichia coli: mutant hosts that allow synthesis of some membrane proteins and globular proteins at high levels. J Mol Biol 260:289-98.

75. Miyaji, E. N., W. O. Dias, M. Gamberini, V. C. Gebara, R. P. Schenkman, J. Wild, P. Riedl, J. Reimann, R. Schirmbeck, and L. C. Leite. 2001. PsaA (pneumococcal surface adhesin A) and PspA (pneumococcal surface protein A) DNA vaccines induce humoral and cellular immune responses against Streptococcus pneumoniae. Vaccine 20:805-12.

76. Mora, M., D. Veggi, L. Santini, M. Pizza, and R. Rappuoli. 2003. Reverse vaccinology. Drug Discov Today 8:459-64.

77. Morrison, W. J., H. Offner, and A. A. Vandenbark. 1991. Ganglioside (GM1)-treated T cells shed CD4. Immunopharmacology 22:77-84.

78. Morrison, W. J., H. Offner, and A. A. Vandenbark. 1990. Transmembrane signalling associated with ganglioside-induced CD4 modulation. Immunopharmacology 20:135-41.

79. Moss, J., and M. Vaughan. 1977. Mechanism of action of choleragen. Evidence for ADP-ribosyltransferase activity with arginine as an acceptor. J Biol Chem 252:2455-7.

80. Murdoch, D. 1980. Leptospiral uveitis. Trans Ophthalmol Soc N Z 32:735 .

81. Nakai, K., and M. Kanehisa. 1991. Expert system for predicting protein localization sites in gram-negative bacteria. Proteins 11:95-110.

82. Nally, J. E., J. P. Whitelegge, S. Bassilian, D. R. Blanco, and M. A. Lovett. 2007. Characterization of the outer membrane proteome of Leptospira interrogans expressed during acute lethal infection. Infect Immun 75:766-73.

83. Nascimento, A. L., A. I. Ko, E. A. Martins, C. B. Monteiro-Vitorello, P. L. Ho, D. A. Haake, S. Verjovski-Almeida, R. A. Hartskeerl, M. V. Marques, M. C. Oliveira, C. F. Menck, L. C. Leite, H. Carrer, L. L. Coutinho, W. M. Degrave, O. A. Dellagostin, H. El-Dorry, E. S. Ferro, M. I. Ferro, L. R. Furlan, M. Gamberini, E. A. Giglioti, A. Goes-Neto, G. H. Goldman, M. H. Goldman, R. Harakava, S. M. Jeronimo, I. L. Junqueira-de-Azevedo, E. T. Kimura, E. E. Kuramae, E. G. Lemos, M. V. Lemos, C. L. Marino, L. R. Nunes, R. C. de Oliveira, G. G. Pereira, M. S. Reis, A. Schriefer, W. J. Siqueira, P. Sommer, S. M. Tsai, A. J. Simpson, J. A. Ferro, L. E. Camargo, J. P. Kitajima, J. C. Setubal, and M. A. Van Sluys. 2004. Comparative genomics of two Leptospira interrogans serovars reveals novel insights into physiology and pathogenesis. J Bacteriol 186:2164-72. 
84. Nascimento, A. L., S. Verjovski-Almeida, M. A. Van Sluys, C. B. Monteiro-Vitorello, L. E. Camargo, L. A. Digiampietri, R. A. Harstkeerl, P. L. Ho, M. V. Marques, M. C. Oliveira, J. C. Setubal, D. A. Haake, and E. A. Martins. 2004. Genome features of Leptospira interrogans serovar Copenhageni. Braz J Med Biol Res 37:459-77.

85. Neves, F. O., P. L. Ho, I. Raw, C. A. Pereira, C. Moreira, and A. L. Nascimento. 2004. Overexpression of a synthetic gene encoding human alpha interferon in Escherichia coli. Protein Expr Purif 35:353-9.

86. Oliveira, M. A., O. L. Caballero, A. R. Vago, R. A. Harskeerl, A. J. Romanha, S. D. Pena, A. J. Simpson, and M. C. Koury. 2003. Lowstringency single specific primer PCR for identification of Leptospira. J Med Microbiol 52:127-35.

87. Ooteman, M. C., A. R. Vago, and M. C. Koury. 2006. Evaluation of MAT, IgM ELISA and PCR methods for the diagnosis of human leptospirosis. J Microbiol Methods 65:247-57.

88. Pizza, M., V. Scarlato, V. Masignani, M. M. Giuliani, B. Arico, M. Comanducci, G. T. Jennings, L. Baldi, E. Bartolini, B. Capecchi, C. L. Galeotti, E. Luzzi, R. Manetti, E. Marchetti, M. Mora, S. Nuti, G. Ratti, L. Santini, S. Savino, M. Scarselli, E. Storni, P. Zuo, M. Broeker, E. Hundt, B. Knapp, E. Blair, T. Mason, H. Tettelin, D. W. Hood, A. C. Jeffries, N. J. Saunders, D. M. Granoff, J. C. Venter, E. R. Moxon, G. Grandi, and R. Rappuoli. 2000. Identification of vaccine candidates against serogroup $B$ meningococcus by whole-genome sequencing. Science 287:1816-20.

89. Plank, R., and D. Dean. 2000. Overview of the epidemiology, microbiology, and pathogenesis of Leptospira spp. in humans. Microbes Infect 2:1265-76.

90. Poland, G. A., and R. M. Jacobson. 2001. The prevention of Lyme disease with vaccine. Vaccine 19:2303-8.

91. Ramos, C. R., P. A. Abreu, A. L. Nascimento, and P. L. Ho. 2004. A high-copy T7 Escherichia coli expression vector for the production of recombinant proteins with a minimal $\mathrm{N}$-terminal His-tagged fusion peptide. Braz J Med Biol Res 37:1103-9.

92. Ren, S. X., G. Fu, X. G. Jiang, R. Zeng, Y. G. Miao, H. Xu, Y. X. Zhang, H. Xiong, G. Lu, L. F. Lu, H. Q. Jiang, J. Jia, Y. F. Tu, J. X. Jiang, W. Y. Gu, Y. Q. Zhang, Z. Cai, H. H. Sheng, H. F. Yin, Y. Zhang, G. F. Zhu, M. Wan, H. L. Huang, Z. Qian, S. Y. Wang, W. Ma, Z. J. Yao, Y. Shen, B. Q. Qiang, Q. C. Xia, X. K. Guo, A. Danchin, I. Saint Girons, R. L. Somerville, Y. M. Wen, M. H. Shi, Z. Chen, J. G. $\mathbf{X u}$, and G. P. Zhao. 2003. Unique physiological and pathogenic features of Leptospira interrogans revealed by whole-genome sequencing. Nature 422:888-93.

93. Rossetti, C. A., M. Liem, L. E. Samartino, and R. A. Hartskeerl. 2005. Buenos Aires, a new Leptospira serovar of serogroup Djasiman, isolated from an aborted dog fetus in Argentina. Vet Microbiol 107:241-8.

94. Rossetti, C. A., M. Uhart, G. N. Romero, and W. Prado. 2003. Detection of leptospiral antibodies in caimans from the Argentinian Chaco. Vet Rec 153:632-3.

95. Sambrook, J., P. MacCallum, and D. Russell. 2001. Molecular cloning: a laboratory manual, Third ed. Cold Spring Harbor. 
96. Scarselli, M., M. M. Giuliani, J. Adu-Bobie, M. Pizza, and R. Rappuoli. 2005. The impact of genomics on vaccine design. Trends Biotechnol 23:84-91.

97. Schaffer, A. A., L. Aravind, T. L. Madden, S. Shavirin, J. L. Spouge, Y. I. Wolf, E. V. Koonin, and S. F. Altschul. 2001. Improving the accuracy of PSI-BLAST protein database searches with compositionbased statistics and other refinements. Nucleic Acids Res 29:2994-3005.

98. Schnitzler, A. C., J. M. Burke, and L. M. Wetzler. 2007. Induction of cell signaling events by the cholera toxin B subunit in antigen-presenting cells. Infect Immun 75:3150-9.

99. Schon, A., and E. Freire. 1989. Thermodynamics of intersubunit interactions in cholera toxin upon binding to the oligosaccharide portion of its cell surface receptor, ganglioside GM1. Biochemistry 28:5019-24.

100. Schultz, J., F. Milpetz, P. Bork, and C. P. Ponting. 1998. SMART, a simple modular architecture research tool: identification of signaling domains. Proc Natl Acad Sci U S A 95:5857-64.

101. Seijo, A., H. Coto, J. San Juan, J. Videla, B. Deodato, B. Cernigoi, O. G. Messina, O. Collia, D. de Bassadoni, R. Schtirbu, A. Olenchuk, G. D. de Mazzonelli, and A. Parma. 2002. Lethal leptospiral pulmonary hemorrhage: an emerging disease in Buenos Aires, Argentina. Emerg Infect Dis 8:1004-5.

102. Seixas, F. K., E. F. da Silva, D. D. Hartwig, G. M. Cerqueira, M. Amaral, M. Q. Fagundes, R. G. Dossa, and O. A. Dellagostin. 2007. Recombinant Mycobacterium bovis BCG expressing the LipL32 antigen of Leptospira interrogans protects hamsters from challenge. Vaccine 26:88-95.

103. Sellati, T. J., L. D. Abrescia, J. D. Radolf, and M. B. Furie. 1996. Outer surface lipoproteins of Borrelia burgdorferi activate vascular endothelium in vitro. Infect Immun 64:3180-7.

104. Sellati, T. J., M. J. Burns, M. A. Ficazzola, and M. B. Furie. 1995. Borrelia burgdorferi upregulates expression of adhesion molecules on endothelial cells and promotes transendothelial migration of neutrophils in vitro. Infect Immun 63:4439-47.

105. Shamaei-Tousi, A., M. J. Burns, J. L. Benach, M. B. Furie, E. I. Gergel, and S. Bergstrom. 2000. The relapsing fever spirochaete, Borrelia crocidurae, activates human endothelial cells and promotes the transendothelial migration of neutrophils. Cell Microbiol 2:591-9.

106. Shivakumar, S., and P. S. Shareek. 2004. Diagnosis of leptospirosis utilizing modified Faine's criteria. J Assoc Physicians India 52:678-9.

107. Shpilberg, O., Y. Shaked, M. K. Maier, D. Samra, and Y. Samra. 1990. Long-term follow-up after leptospirosis. South Med J 83:405-7.

108. Stanchi, N. O. 2006. Leptospiras y Borrelias, p. 502-508. In J. A. Basualdo, C. E. Coto, and R. A. de Torres (ed.), Microbiología biomédica, 2da ed. Atlante, Buenos Aires.

109. Thomas, W., and R. Sellwood. 1993. Molecular cloning, expression, and DNA sequence analysis of the gene that encodes the 16-kilodalton outer membrane lipoprotein of Serpulina hyodysenteriae. Infect Immun 61:1136-40.

110. Tung, W. L., and K. C. Chow. 1995. A modified medium for efficient electrotransformation of E. coli. Trends Genet 11:128-9. 
111. Turhan, V., E. M. Atasoyu, Y. Kucukardali, E. Polat, T. Cesur, and S. Cavuslu. 2006. Leptospirosis presenting as severe rhabdomyolysis and pulmonary haemorrhage. J Infect 52:e1-2.

112. Verma, A., J. Hellwage, S. Artiushin, P. F. Zipfel, P. Kraiczy, J. F. Timoney, and B. Stevenson. 2006. LfhA, a novel factor H-binding protein of Leptospira interrogans. Infect Immun 74:2659-66.

113. Vijayacharit, P., R. A. Hartskeerl, S. Sharma, K. Natarajaseenivasan, S. Roy, W. J. Terpstra, and S. C. Sehgal. 2004. A unique strain of Leptospira isolated from a patient with pulmonary haemorrhages in the Andaman Islands: a proposal of serovar portblairi of serogroup Sehgali. Epidemiol Infect 132:663-73.

114. Wagenaar, J. F., P. J. de Vries, and R. A. Hartskeerl. 2004. Leptospirosis with pulmonary hemorrhage, caused by a new strain of serovar Lai: Langkawi. J Travel Med 11:379-81.

115. Weigel, L. M., J. D. Radolf, and M. V. Norgard. 1994. The 47-kDa major lipoprotein immunogen of Treponema pallidum is a penicillinbinding protein with carboxypeptidase activity. Proc Natl Acad Sci U S A 91:11611-5.

116. Weis, F. M., and R. J. Davis. 1990. Regulation of epidermal growth factor receptor signal transduction. Role of gangliosides. J Biol Chem 265:12059-66.

117. Wu, J., and H. R. Kaback. 1996. A general method for determining helix packing in membrane proteins in situ: helices I and II are close to helix VII in the lactose permease of Escherichia coli. Proc Natl Acad Sci U S A 93:14498-502.

118. Yamamoto, S., Y. Takeda, M. Yamamoto, H. Kurazono, K. Imaoka, K. Fujihashi, M. Noda, H. Kiyono, and J. R. McGhee. 1997. Mutants in the ADP-ribosyltransferase cleft of cholera toxin lack diarrheagenicity but retain adjuvanticity. J Exp Med 185:1203-10.

119. Yoder, A., X. Wang, Y. Ma, M. T. Philipp, M. Heilbrun, J. H. Weis, C. J. Kirschning, R. M. Wooten, and J. J. Weis. 2003. Tripalmitoyl-Sglyceryl-cysteine-dependent OspA vaccination of toll-like receptor 2deficient mice results in effective protection from Borrelia burgdorferi challenge. Infect Immun 71:3894-900.

120. Zuerner, R. L., J. L. Herrmann, and I. Saint Girons. 1993. Comparison of genetic maps for two Leptospira interrogans serovars provides evidence for two chromosomes and intraspecies heterogeneity. J Bacteriol 175:5445-51. 